\title{
The Treatment of Accounting Changes in Covenants and Debt Contracting Efficiency*
}

\author{
Chunmei Zhu \\ c39zhu@uwaterloo.ca \\ School of Accounting and Finance \\ University of Waterloo
}

July 2020

\footnotetext{
*I am sincerely grateful to my thesis advisor, Christine Wiedman, and committee members, Alan Douglas, Steve Fortin and Stephanie Lluis, for their invaluable guidance, support and encouragement. I also thank Tim Bauer, Changling Chen, Duane Kennedy, Patricia O'Brien, Seda Oz, Sasan Saiy, Joyce Tian, Dushyant Vyas (CAAA Craft of Accounting Workshop discussant), Tony Wirjanto, and workshop participants at University of Waterloo, 2018 CAAA Craft of Accounting Research, and Pre-conference workshop of 2019 McGill Accounting Research Conference for their helpful comments. All errors are my own.
} 


\begin{abstract}
Debt contracts contain accounting-based covenants that could be affected by changes in generally accepted accounting principles (GAAP). There are three types of contractual treatment of GAAP changes: excluding GAAP changes (frozen GAAP); incorporating GAAP changes (floating GAAP); and incorporating changes unless either the borrower or the lenders request a freeze (frozen-on-request GAAP). Motivated by the recent increase and current prevalence of frozen-on-request GAAP, I examine whether this type is more useful in promoting debt contracting efficiency than the other two by collecting a large sample of private debt contracts. I use false positives and false negatives as proxies for debt contracting efficiency and find significantly lower false positives and false negatives under frozen-on-request GAAP than under frozen and floating GAAP after controlling for self-selection bias. The reductions are more evident when significant accounting changes relevant for covenants occur and when compared to unconditionally frozen GAAP. I also find that the reductions become weak during financial crisis and when borrowers and lenders have conflicting preferences towards GAAP changes. My study provides new evidence on the role of accounting standards and GAAP provision designs in improving debt contracting efficiency.
\end{abstract}




\section{Introduction}

Debt contracts are incomplete as it is difficult to forecast all future events that may occur and all actions that are appropriate in these events. Accounting-based covenants are used to mitigate the contractual incompleteness by serving as "...a measurement system that maps states of the world into accounting numbers and thus facilitates state contingent control allocation..." (Christensen and Nikolaev 2017, page 22). However, generally accepted accounting standards (GAAP) evolve over time as evidenced by the establishment of new rules and the improvement in existing rules by standard-setting bodies. The evolving GAAP could affect covenant calculations and thereby affect borrowers' compliance with covenants and control right allocations. An example is a change in lease accounting that requires the recognition of operating leases on the balance sheet (FASB Topic 842). This new standard could substantially change borrowers' balance-sheet profile and trigger the violation of affected covenants $^{1}$, and therefore it has been widely discussed among practitioners and in the media. ${ }^{2}$

The FASB frequently issues accounting standards updates ${ }^{3}$ and the private debt is an important source of firm capital ${ }^{4}$, leading borrowers and lenders to be frequently confronted with the

\footnotetext{
${ }^{1}$ Although in most cases lenders will grant a waiver, the waiver is not totally free and covenant violations are costly to borrowers. Prior studies such as Nini, Smith, and Sufi (2012) and Chava and Roberts (2008) find that after debt covenant violations, lenders will intervene in borrowers' operating, financing, and investment activities and corporate governance. In addition to the increased lenders' control, borrowers' refinancing costs and restructuring costs will also increase (Beneish and Press 1993).

${ }^{2}$ See http://ww2.cfo.com/gaap-ifrs/2014/02/lease-accounting-changes-jar-bank-covenants/.

Another anecdotal example of accounting changes impacting covenants is the change in the classification of warranty. As mentioned in ARTISTdirect Inc.'s 10-Q for June 30, 2008: "Due to the accounting classification of the warranty issued in conjunction with the Senior Financing and the Sub-Debt Financing as a current liability in accordance with SFAS No. 133 and EITF 00-19, the Company was not in compliance with certain of these financial covenants at December 31, 2005. On April 7, 2006, the lenders provided waivers with respect to such past events of default under the Senior Notes and amended their loan documents such that the warrant liability and any change thereto in future periods will not affect future covenant".

${ }^{3}$ Based on the accounting standards updates (including improvements and amendments to existing standards) disclosed on the website of FASB, the FASB issued 16.7 accounting changes per year on average from 2009 to 2018 (https://www.fasb.org/jsp/FASB/Page/SectionPage\&cid=1176156316498).

${ }^{4}$ The size of U.S. commercial and industrial loans reached $\$ 2.35$ trillion in July 2019 based on the statistics from the Federal Reserve System (https://fred.stlouisfed.org/series/BUSLOANS).
} 
question on how to address the impact of GAAP changes on accounting-based covenants. In private debt contracts, there are three types of GAAP provisions that are used to address this impact. I investigate the effect of the three types on debt contracting efficiency.

The first type is frozen GAAP, which means for the purpose of determining covenant compliance, the borrower will apply GAAP in effect on the closing date of the contract throughout the term. ${ }^{5}$ This type reduces the risk underlying GAAP changes at the expense of restricting possible benefits of improved GAAP and keeping multiple sets of accounting books. The second type is floating GAAP that incorporates future GAAP changes into covenant calculations. This type benefits from improved GAAP but may worsen contracts if GAAP changes hinder the covenants' ability to capture the state of nature. The third is frozen-onrequest GAAP, where floating GAAP is used until either the borrower or the lenders request the continued use of GAAP in effect immediately before the request. This type can incorporate improved GAAP and allow the elimination of GAAP changes that hinder the covenants' ability to capture the state of nature, but granting an option to freeze GAAP changes is not always good for debt contracting efficiency.

Prior studies (e.g., Leftwich 1983; EL-Gazzar and Pastena 1990; Mohrman 1993, 1996; Darrough and Deng 2017) focus on frozen versus floating GAAP. There is little evidence on the use of frozen-on-request GAAP partly because this type was regarded as one type of frozen GAAP and only became common within the last decade. ${ }^{6}$ I collect 18,923 private debt contracts from the Electronic Data Gathering, Analysis, and Retrieval system (EDGAR) and find that

\footnotetext{
${ }^{5}$ Mohrman (1996) uses the term "fixed GAAP" provisions to refer to "the provisions that ensure that the terms of the contract will be unaffected by future accounting method changes" (page 79).

${ }^{6}$ Most studies combine frozen-on-request GAAP contracts with frozen GAAP. The exception is the Internet Appendix of Christensen and Nikolaev (2017), which separates frozen-on-request GAAP from frozen GAAP and shows that the use of frozen-on-request GAAP increased significantly from 1994 to 2005.
} 
frozen-on-request GAAP increased from $7.4 \%$ in 1996 to $66.5 \%$ in 2017 and is currently the most prevalent GAAP provision type (see Figure 1 Panel A).

Motivated by the significant increase in its use, I explore whether frozen-on-request GAAP can better address the impact of GAAP changes on debt covenants than frozen and floating GAAP and therefore promote debt contracting efficiency. To capture the efficiency of GAAP provisions in addressing the impact of GAAP changes, I adopt Gigler, Kanodia, Sapra, and Venugopalan (2009)'s definition of debt contracting efficiency that minimizes the errors due to false alarms and missed early warnings. Based on this definition, I use two proxies for debt contracting efficiency, false positives (i.e., covenant violations occur when borrowers' creditworthiness does not deteriorate below the original intent of thresholds) and false negatives (i.e., covenant violations do not occur when borrowers' creditworthiness deteriorates below the original intent of thresholds).

To develop my predictions about false positives and false negatives under the three types of GAAP provisions, I first consider a simplified case before contract renegotiations for subsequent accounting changes. I assume that borrowers care more about the effect of GAAP changes on covenant tightness while lenders care more about the effect on debt contracting efficiency. Under frozen-on-request GAAP, GAAP changes detrimental to debt contracting efficiency are excluded from covenant calculations by lenders, but GAAP changes beneficial to debt contracting efficiency are not necessarily incorporated into covenant calculations because borrowers would request to freeze GAAP changes beneficial to efficiency but tightening covenants. For example, the new GAAP on consolidation of variable interest entities helps reflect the true financial position and performance but tightens covenants such as the 
maximum leverage and the minimum earnings, and therefore borrowers have incentives to reject this GAAP change. Although borrowers would reject GAAP changes beneficial to efficiency, frozen-on-request GAAP remains more useful in capturing borrowers' state than frozen and floating GAAP because frozen GAAP excludes all GAAP changes and floating GAAP incorporates all GAAP changes. That means compared to frozen and floating GAAP, frozen-on-request GAAP is more useful in reducing false positives and false negatives before contract renegotiations.

Next, I consider the case where renegotiation costs are trivial. Here, GAAP changes can always be renegotiated away at trivial costs, implying that there would be no difference in false positives and false negatives under the three types of GAAP provisions. Finally, I consider the more typical scenario where renegotiation costs are non-trivial. Frozen-on-request GAAP saves renegotiation costs and facilitates renegotiations and thereby better restores the ex post efficiency, compared to frozen and floating GAAP. This is because under frozen-on-request GAAP, no renegotiation is needed when borrowers and lenders have the same preference towards GAAP changes, and the two parties cannot reject renegotiations when they have conflicting preferences. The tension arises if borrowers abuse renegotiations under frozen-onrequest GAAP to push lenders to agree to reject GAAP changes beneficial to efficiency but tightening covenants. Jointly considering frozen-on-request GAAP's advantages in improving efficiency before renegotiations and restoring the ex post efficiency after renegotiations, I expect lower false positives and false negatives under frozen-on-request GAAP than under frozen and floating GAAP.

To empirically test my expectations, I employ Heckman (1979)'s selection model to 
mitigate the concerns on self-selection bias. I construct a choice model of frozen-on-request GAAP and find that the use of this type depends on the relative negotiation power of borrowers and lenders, the cost of keeping multiple sets of accounting books, renegotiation costs, borrowers' financial conservatism, and the protection of collateral specified in debt contracts.

In the outcome model, I apply two measures of false positives following Demerjian, Donovan, and Lewis-Western (2020). First, I identify false positives as the situation where borrowers have positive abnormal stock returns in one preceding quarter and the concurrent quarter but report covenant violations in the concurrent quarter. Second, I define false positives as an alternative situation where borrowers have credit rating upgrades in one year prior to covenant violations. For both measures, I find that facilities with frozen-on-request GAAP are less likely to experience false positives than facilities with frozen and floating GAAP. I find similar results for a probit regression as a robustness test of Heckman model, and for the Penalized Maximum Likelihood Estimation (Firth 1993) that is used to correct for the likelihood of rare events.

I measure false negatives as the number of months between the first negative stock price shock and the first covenant violation following the shock or the sample ending/loan maturity if there is no covenant violation (Zhang 2008). The smaller the number of months, the lower the false negatives. I collect a sample of 1,322 facilities that experience at least one negative stock price shock between facility initiation and the sample ending or the maturity dates. Consistent with my prediction, the number of months under facilities with frozen-on-request GAAP is smaller relative to facilities with frozen and floating GAAP, indicating lower false negatives under frozen-on-request GAAP. 
Next, I consider the variation in accounting standard setting activities. I expect that the above advantages of frozen-on-request GAAP in reducing false positives and false negatives are greater when significant accounting changes relevant for financial covenants occur. I identify fifteen Statement of Financial Accounting Standards (SFAS) that are the most relevant standards to covenants for my sample period, and establish criteria to select affected firms for each SFAS. I then compare the affected firms' false positives and false negatives in the three years before versus after effective dates. Consistent with my expectation, the reductions in false positives and false negatives under frozen-on-request GAAP are more pronounced in the post period.

To test the role of reduced renegotiation costs in helping frozen-on-request GAAP improve debt contracting efficiency, I compare frozen-on-request GAAP with two types of frozen GAAP (1) unconditionally frozen (i.e., frozen provisions that do not mention renegotiations in the GAAP provision), and (2) frozen with renegotiation (i.e., frozen provisions that mention and allow renegotiations in the GAAP provision). As the latter type could also facilitate renegotiations, frozen-on-request GAAP's advantages may diminish when compared to the latter type. Thus, I argue and document that the reductions in false positives and false negatives under frozen-on-request GAAP are more pronounced relative to unconditionally frozen GAAP than relative to frozen GAAP with renegotiation.

In the additional analyses, I identify two scenarios where frozen-on-request GAAP becomes less useful: during the financial crisis when the conflicts between borrowers and lenders increase; and, when borrowers and lenders have conflicting preferences towards GAAP changes. In the two scenarios, I document that false positives under frozen-on-request GAAP 
are not significantly lower than those under frozen and floating GAAP. Next, frozen-on-request GAAP has two types. In one type renegotiations are necessary when borrowers or lenders request a freeze and in the other type renegotiations are not necessary (see examples in Appendix I). I find that the two types have similar abilities to reduce false positives but frozenon-request GAAP with renegotiation is more useful in reducing false negatives, highlighting its advantages in facilitating renegotiations.

I also conduct a number of sensitivity analyses to demonstrate the robustness of my findings. In specific, I construct a new measure of false positives based on bond returns to mitigate concerns of using stock returns as a proxy for borrowers' creditworthiness. Similar to the results based on stock returns, I find lower false positives under frozen-on-request GAAP with this new measure. To mitigate the concern that my results of false negatives are sensitive to the cutoff used to identify the negative stock price shock, I use an alternative cutoff and find robust results based on the new cutoff. Further, I examine the effect of frozen-on-request GAAP on loan spreads based on agency theory and find lower spreads under frozen-on-request GAAP than under frozen and floating GAAP, supporting my primary findings to some extent. Finally, I conduct robustness tests of multicollinearity in Heckman's selection model following the suggestions from Lennox, Francis, and Wang (2012), and my results remain unchanged.

My study advances the literature on the GAAP provisions in debt contracts in four ways. First, to my knowledge, although frozen-on-request GAAP has been the dominant GAAP provision type in recent years, prior studies have focused mainly on frozen and floating GAAP only with the exception of Christensen and Nikolaev (2017) who provide some preliminary evidence on the determinants of frozen-on-request GAAP. My study provides systematic 
evidence on the determinants of frozen-on-request GAAP, extending Christensen and Nikolaev (2017). Second, distinguishing from Beatty, Ramesh, and Weber (2002) who test the effect of GAAP provisions on cost of capital, a proxy for debt contracting efficiency, I examine the effect on false positives and false negatives, direct measures to capture the effect of GAAP provisions and an unexplored but fundamental consequence. Third, I provide important evidence on the advantages of frozen-on-request GAAP in incorporating and excluding GAAP changes and in reducing renegotiation costs and facilitating renegotiation. Lastly, I categorize the scenarios where frozen-on-request GAAP is more useful in reducing false positives and false negatives than frozen and floating GAAP and the scenarios where frozen-on-request GAAP may not be more useful. My findings should be of interest to practitioners by illustrating how the ex ante choice of GAAP provisions helps to address the impact of evolving GAAP on debt covenants.

More broadly, this study contributes to the literature on the debt contracting efficiency role of accounting information. The incorporation and exclusion of GAAP changes under frozen-on-request GAAP increase the effectiveness of debt covenants in allocating statecontingent control rights and thus improve debt contracting efficiency. I also show that the improvement is more pronounced when significant accounting changes relevant for covenants occur. Collectively, my findings shed new lights on the role of GAAP changes in improving debt contracting efficiency, and respond to Christensen, Nikolaev, and Wittenberg-Moerman (2016)'s call for research on the role of accounting standards in debt contracting.

The remainder of this paper is organized as follows. Section 2 provides a review of relevant literature and develops research hypotheses. Section 3 outlines the sample construction 
and research models. Section 4 presents descriptive statistics and main results. In section 5, I conduct several additional analyses. The final section concludes.

\section{Literature Review and Hypothesis Development}

Based on positive accounting theory that emphasizes the role of accounting in contracting process (Watts and Zimmerman 1978, 1979, and 1990), a stream of literature on the role of accounting information in debt contracting efficiency has emerged. This stream of literature explores the association between accounting information and debt contracts including: conservatism and loan characteristics (e.g., Wittenberg-Moerman 2008); covenant definition adjustments (e.g., Beatty, Weber, and Yu 2008; Li 2010, 2016; Demerjian and Owens 2016; Dyreng, Vashishtha, and Weber 2017; Beatty, Cheng, and Zach 2019); the effect of specific accounting changes (such as SFAS 141 and 142) or general standard changes (such as the adoption of balance sheet approach) on covenant choices (e.g., Frankel, Seethamraju, and Zach 2008; Demerjian 2011); and, the use and determinants of different GAAP provision types (e.g., Leftwich 1983; Mohrman 1996; Beatty et al. 2002; Christensen and Nikolaev 2017).

GAAP provisions in debt contracts deal with the effect of accounting changes on covenant calculations and thereby affect the ability of covenants to capture borrowers' state. Based on incomplete contracting theory (Aghion and Bolton 1992), when borrowers are in the good state (i.e., they do not violate covenants), they keep control rights because they have incentives to maximize monetary return and nonmonetary private benefits, which result in the maximum of future cash flows payable to lenders. However, when borrowers are in the bad state (i.e., they violate covenants), control rights should be allocated to lenders because 
borrowers are more likely to sacrifice lenders' interests and take inefficient actions largely due to their nonmonetary private benefits. By affecting the covenants' ability to capture the state of nature, GAAP provisions can affect control right allocations contingent on the state and therefore impact on debt contracting efficiency.

To capture the above effect of GAAP provisions, I adopt the definition of debt contracting efficiency suggested by Gigler et al. (2009) in which "the optimal debt arrangement minimizes the sum of the expected opportunity costs arising from two kinds of decision errors: errors due to false alarms and errors due to undue optimism. These errors are analogous to the Type I and Type II decision errors that arise in any binary decision setting” (page 770). Based on this definition, I use false positives and false negatives to measure debt contracting efficiency. The opportunity costs arising from false positives are high because (1) borrowers need to communicate to lenders that the covenant violations do not indicate an increase in credit risk and the communication involves borrowers' time and efforts; (2) borrowers may tailor their investment (Darrough and Deng 2017), financing (Cohen, Katz, Mutlu, and Sadka 2019), and operating activities in anticipation of future false positives; and (3) inefficient control right transfer would be triggered and may result in the hold-up problem. ${ }^{7}$ False negatives are also costly because missing early warnings of creditworthiness deteriorations could lead to inefficient continuation decisions and thus transfer wealth from lenders to shareholders (Caskey and Hughes 2012). The reduced false positives and false negatives could minimize those opportunity costs arising from inefficient control right allocations, and therefore result in

\footnotetext{
${ }^{7}$ Hold-up problem occurs when one party makes a sunk and non-contractible specific investment to prepare a future transaction and the other party can expropriate returns from the investment (Klein, Crawford and Alchian 1978). For example, suppose that a lender provides a loan for the purpose of R\&D to a borrower and an accounting change affects covenant calculation and causes false positives. When the borrower requests a waiver from the lender, the lender may hold up the borrower by requiring extra gains from the R\&D project to exchange the waiver.
} 
more efficient debt contracts.

As mentioned above, GAAP provisions have three types in practice. I investigate whether frozen-on-request GAAP is more useful in improving debt contracting efficiency than frozen and floating GAAP by testing whether it leads to lower false positives and false negatives.

A mission of the FASB is to "keep standards current to reflect changes in methods of doing business and changes in the economic environment" (FASB 2007). ${ }^{8}$ To achieve this mission, the FASB shifted its objective from reliability to relevance and issues substantial GAAP changes. As lenders demand relevant and reliable accounting information, GAAP changes are beneficial to debt contracting efficiency if they are informative of borrowers' future cash flow payable to lenders (e.g., Dyreng et al. 2017) and reliable (e.g., Demerjian 2011). Donelson, Jennings, and Mcinnis (2017) find that around 89\% of bank lenders hold a neutralto-positive view of the debt contracting efficiency of U.S. GAAP changes over the last 10 years. However, some GAAP changes reduce debt contracting efficiency because they are uninformative about future cash flows or unreliable. A specific example is SFAS 141 and 142, which replace the amortization of goodwill by the measurement of goodwill through impairment testing. The goodwill impairment is a nonrecurring item that may lack cash flow predictive ability (Beatty et al. 2019) and is also subject to borrower manipulations (Watts 2006; Beatty and Weber 2006), thus adding noise to covenant calculations (Frankel et al. 2008). To reduce false positives and false negatives, GAAP provisions should incorporate GAAP changes beneficial to debt contracting efficiency and exclude GAAP changes detrimental to debt

\footnotetext{
${ }^{8} \mathrm{http}: / /$ www.fasb.org/facts/facts_about_fasb.pdf
} 
contracting efficiency.

I analyze the incorporation and exclusion of GAAP changes under the three types of GAAP provisions by starting with a simplified case without considering renegotiations (i.e., before renegotiations). (This simplified case and the following discussion are also summarized in tabular format in Figure 2.) Under this scenario, I assume that borrowers care more about the effect of GAAP changes on covenant tightness ${ }^{9}$ because covenant violations are costly for borrowers. I also assume that lenders care more about the effect on debt contracting efficiency for two reasons. First, if lenders also care more about the effect on covenant tightness, then all GAAP changes relevant to covenants would be rejected either by borrowers or by lenders, suggesting no difference between frozen-on-request GAAP and frozen GAAP. Second, lenders use covenants to monitor borrowers' creditworthiness, and therefore it is crucial to use accounting information beneficial to debt contracting efficiency to calculate covenants to reflect borrowers' true state. ${ }^{10}$

Under this assumption, lenders would reject GAAP changes detrimental to debt contracting efficiency and accept GAAP changes beneficial to debt contracting efficiency even if the changes loosen covenants. I take Revenue from Contracts with Customers (ASC 606) as an example. By adopting this GAAP change, telecommunication firms will allocate more of

\footnotetext{
${ }^{9}$ One may argue that GAAP changes have different influences on different types of financial covenants (i.e., capital covenants versus performance covenants). To test the potential different influences, I need to compare the probabilities of false positives and false negatives between debt contracts containing only capital covenants and debt contracts containing only performance covenants. However, more than $90 \%$ of debt contracts in my false positives sample and false negatives sample contain performance covenants, suggesting that the number of debt contracts containing only capital covenants is small. Moreover, to capture the probabilities of false positives and false negatives, at least some contracts in my samples experience covenant violations. Under the two restrictions, the sample size of contracts containing only capital covenants and experiencing covenant violations is too small to allow me to test the potential different influences.

${ }^{10}$ This is consistent with the findings in Dyreng et al. (2017) that the earnings measures used to calculate covenants are not conditionally conservative but are more predictive of borrowers' future cash flow than GAAP earnings.
} 
the transaction price to the equipment at the delivery because the revenue from selling the equipment will be measured using relative standalone selling prices rather than cash received, resulting in an early recognition of revenue. This GAAP change can loosen earnings covenants but better capture the changes in borrowers' creditworthiness by reflecting the underlying economics of transactions. Therefore, lenders would accept this GAAP change.

Borrowers would accept GAAP changes loosening covenants and reject GAAP changes tightening covenants even if the changes are beneficial to debt contracting efficiency. I take the standard on consolidation of variable interest entities (FASB Interpretation No. 46) as an example. This GAAP change requires the recognition of off-balance sheet liabilities, and therefore would better reflect borrowers' underlying indebtedness but deteriorate borrowers' maximum leverage covenants. As a response, borrowers can request a freeze. ${ }^{11}$ In this example, frozen-on-request GAAP cannot help reduce false negatives, implying that granting an option to reject GAAP changes under frozen-on-request GAAP is not always good for debt contracting efficiency. Although frozen-on-request GAAP is not perfect, it remains more useful in reducing false positives and false negatives than frozen and floating GAAP because frozen GAAP excludes all accounting changes and floating GAAP incorporates all GAAP changes before renegotiations.

In practice, debt covenants are renegotiable. ${ }^{12}$ Renegotiation costs can be trivial in some non-syndicated private debt contracts. When this is the case, GAAP provisions are expected to be moot, i.e., there would be no difference in false negatives and false positives among the

\footnotetext{
${ }^{11}$ Accompanying the request, borrowers in most cases need to submit an explanation statement. As the statement may reveal borrowers' disadvantageous information such as an accounting signal about a bad project state, borrowers may be reluctant to request such a freeze.

${ }^{12}$ Covenant renegotiations could occur without covenant violations (Denis and Wang 2014).
} 
three types, because accounting changes could be renegotiated away at trivial costs. However, in general, renegotiation costs are non-trivial because syndicated loans have become more and more common and the amendment fees that borrowers need to pay can be up to 100 basis points of total credit commitment. ${ }^{13}$ Renegotiations can restore the ex-post efficiency of debt contracts when the ex-ante control right allocation designed at contract initiation becomes suboptimal ex post (Grossman and Hart 1986; Huberman and Kahn 1988). I compare the renegotiation costs under the three GAAP provision types in three scenarios as follows and summarize this discussion in Figure 3.

First, suppose that both borrowers and lenders prefer the new GAAP. Under frozen-onrequest and floating GAAP, no renegotiation is needed, while under frozen GAAP the two parties need to renegotiate to amend the existing contract. Second, suppose that both prefer the old GAAP. Under frozen-on-request GAAP, either party can request contract amendments to freeze GAAP changes until the request has been withdrawn or the contract is amended (i.e., renegotiation is not necessarily needed) or the two parties enter into renegotiations upon the request to freeze (i.e., renegotiation is necessary). However, no renegotiation is needed to amend contracts under frozen GAAP but renegotiations are required under floating GAAP. The renegotiation outcome in the two scenarios is to restore efficiency because GAAP changes beneficial (detrimental) to debt contracting usefulness will be incorporated into (excluded from) covenant calculations based on the above assumption. Therefore, I argue that compared to frozen and floating GAAP, frozen-on-request GAAP can save renegotiation costs and thereby

\footnotetext{
${ }^{13}$ Other expenses include attorneys' fees, stamp and other taxes, search fees, filing fees, and other costs and expenses occurring during the execution and delivery of amendments. In addition to these observable costs, reputation concerns and relationship-maintenance concerns are also costly during the renegotiation process. The magnitude of these costs is higher than we assume (Skinner 2011).
} 
restore the ex post efficiency at a lower cost when borrowers and lenders have the same preference to GAAP changes. One concern is that the renegotiation costs in the two scenarios would be trivial because renegotiations increase the total surplus. However, in a syndicated loan, to make a nonmaterial amendment, it requires the approval of lenders holding a certain percentage of the loan amount (at least $50 \%$ based on Saavedra 2018's statistics), and if the amendment is material, it requires the approval of all lenders (Standard \& Poor's 2011). Anecdotal and research evidence suggest that potential delays in obtaining lender agreement and hold-up by some participant lenders increase coordination difficulties during the renegotiation of syndicated loans (e.g., Bris and Welch 2005; Saavedra 2018), resulting in nontrivial renegotiation costs.

Third, suppose that the two parties have preference conflicts. Under frozen and floating GAAP, either party can reject renegotiations. In contrast, under frozen-on-request GAAP where renegotiations are necessary, if either party requests a freeze, the other party shall enter into renegotiations in good faith, implying the advantage of frozen-on-request GAAP in facilitating renegotiations. However, facilitating renegotiations does not necessarily restore ex-post efficiency because borrowers may abuse renegotiations to force lenders to agree to reject GAAP changes beneficial to debt contracting efficiency but tightening covenants. I therefore posit that frozen-on-request GAAP may not restore the ex-post efficiency at a lower cost when borrowers and lenders have conflicting preferences.

Combining frozen-on-request GAAP's advantages in incorporating and excluding GAAP changes before renegotiations, and its reduced renegotiation costs when considering renegotiations, I expect lower false positives and false negatives under frozen-on-request 
GAAP. Therefore, I hypothesize that

H1a: False positives are lower for debt contracts with frozen-on-request GAAP provisions than for contracts with frozen and floating GAAP.

H1b: False negatives are lower for debt contracts with frozen-on-request GAAP provisions than for contracts with frozen and floating GAAP.

However, I note that there are reasons to expect no change or even an increase in false positives and false negatives under frozen-on-request GAAP. First, as mentioned above, borrowers may abuse the option granted and the renegotiations under frozen-on-request GAAP to reject GAAP changes beneficial to debt contracting efficiency but tightening covenants. Second, for some GAAP changes with a long interval between the exposure draft date and the effective date, borrowers and lenders can specify how to treat these GAAP changes at contract initiation. For example, the new GAAP on leases was issued in May 2013 but did not go into effect until December 2018. Some of loan contracts initiated between the two dates already specified the treatment of this GAAP change, indicating that there would be no difference in the effect of this accounting change on false positives and false negatives under the three types. ${ }^{14}$ Third, the literature on the value of contract commitment supports frozen GAAP because contracts should be rigid to reduce borrowers' fears that the subsequent bargaining will deprive them of the non-contractible effort/investment value when the non-contractible effort/investment value is necessary for their success (Rogerson 1992). Similarly, the asset substitution $^{15}$ literature also supports frozen GAAP because in anticipation of disadvantageous

\footnotetext{
${ }^{14}$ An example is a term loan credit agreement between AT\&T Inc. and JPMorgan Chase Bank on October 22, 2016: "whether a lease constitutes a capital lease or an operating lease shall be determined based on GAAP as in effect on the date hereof, notwithstanding any modification or interpretative change thereto after the date hereof (including without giving effect to any treatment of leases under Accounting Standards Codification 842 or any other Accounting Standards Codification or Financial Accounting Standard having a similar result or effect)".

${ }^{15}$ Asset substitution problem refers to borrowers' behavior of replacing low-risk assets/projects by high-risk assets/projects and lenders' behavior of forcing borrowers to take too little risk when lenders have too much power.
} 
information revelation and covenant violations caused by GAAP changes, borrowers may engage in more risky projects ex ante (Darrough and Deng 2017). Both streams of literature suggest that frozen GAAP leads to more efficient investments and therefore improves debt contracting efficiency.

In the above hypothesis, I assume that borrowers will experience significant GAAP changes over the term of the debt contract. However, there is variation in standard setting activity. Accounting changes can significantly affect debt covenants if the changes are related to the recognition and measurement of accounting elements used in covenants, but may not significantly affect covenants if the changes are immaterial to firms, relate only to disclosures, are relevant for only one particular industry, or relate to accounting elements that are not used in covenants. Given this variation, I predict that the advantages of frozen-on-request GAAP in reducing false positives and false negatives are more pronounced for significant accounting changes relevant to covenants. Accordingly, I state my second hypothesis as follows:

H2a: The reduction in false positives for debt contracts with frozen-on-request GAAP is more pronounced for significant accounting changes relevant to debt financial covenants.

H2b: The reduction in false negatives for debt contracts with frozen-on-request GAAP is more pronounced for significant accounting changes relevant to debt financial covenants.

As mentioned above, frozen-on-request GAAP is further split into two types: (1) either borrowers or lenders can request to freeze GAAP changes until the request has been withdrawn or the contract is amended (i.e., renegotiation is not necessarily needed and therefore this type is termed as frozen-on-request GAAP without renegotiation), and (2) the two parties enter into renegotiations upon the request to freeze (i.e., renegotiation is necessary and therefore this type 
is termed as frozen-on-request GAAP with renegotiation). See Appendix I for examples. Using the variation in renegotiations within frozen-on-request GAAP, I analyze the role of frozen-onrequest GAAP's advantage in reducing renegotiation costs and facilitating renegotiations in reducing false positives and false negatives. To facilitate the analyses, I combine Figure 2 and Figure 3 and summarize the following discussion in Figure 4.

Note that incorporating GAAP changes beneficial to efficiency but tightening covenants (Scenario 1) and excluding GAAP changes detrimental to efficiency but loosening covenants (Scenario 4) can reduce false negatives, and incorporating GAAP changes beneficial to efficiency but loosening covenants (Scenario 2) and excluding GAAP changes detrimental to efficiency but tightening covenants (Scenario 3) can reduce false positives. Scenarios 2 and 3 are related to false positives and scenarios 1 and 4 are related to false negatives.

In scenarios 2 and 3, borrowers and lenders have the same preference to GAAP changes. Under frozen-on-request GAAP without renegotiation, if both prefer new GAAP, then neither will send a request to reject the GAAP change and therefore no renegotiation is needed; and if both prefer old GAAP, then one party sends a request and the other party does not need to take any action and therefore also no renegotiation is needed, implying that this type can save renegotiation costs. Under FOR with renegotiation, if both prefer new GAAP, neither will send a request; and if both prefer old GAAP, then the two parties need to enter into renegotiations. Under frozen GAAP, renegotiation is required to amend the contract to include the use of new GAAP when both prefer new GAAP but no renegotiation is required when both prefer old GAAP. In contrast, under floating GAAP, no renegotiation is needed when both prefer new GAAP but renegotiation is required to amend the contract to exclude the use of new GAAP 
when both prefer old GAAP. Therefore, I expect that the reduction in false positives will be more pronounced under frozen-on-request GAAP without renegotiation than under frozen-onrequest GAAP with renegotiation.

In scenarios 1 and 4, borrowers and lenders have conflicting preferences towards GAAP changes and renegotiations will play an important role. Under frozen-on-request GAAP without renegotiation, frozen, and floating GAAP, either can reject renegotiation. However, the two parties shall enter into renegotiations under frozen-on-request GAAP with renegotiation, suggesting that this type can facilitate renegotiations. Therefore, I argue that the reduction in false negatives will be more pronounced under frozen-on-request GAAP with renegotiation than under frozen-on-request GAAP without renegotiation. As a result, I state my third hypothesis as follows:

H3a: The reduction in false positives is more pronounced for frozen-on-request GAAP without renegotiation.

H3b: The reduction in false negatives is more pronounced for frozen-on-request GAAP with renegotiation.

\section{Research design}

\subsection{Sample construction}

Table 1 outlines the sample selection process. Private debt contracts are disclosed in Exhibit 10 (i.e., material contract) of Securities Exchange Commission (SEC) filings. ${ }^{16}$ I first collect all URLs of Exhibit 10s of SEC forms 10-K, 10-Q, and 8-K filed between January 1994 and December 2017 using SEC Analytics Suite and then download these Exhibit 10s from the

\footnotetext{
${ }^{16}$ Regulation S-K (1980) requires the mandatory disclosure of material contracts in the SEC filings as a form of Exhibit 10.
} 
EDGAR. I restrict Exhibit 10 s to files containing the terms "credit agreement", "loan agreement", or "loan and security agreement"; the words "GAAP" or "Generally Accepted Accounting Principles"; and the words "financial covenants" or "negative covenants". ${ }^{17}$ Following Christensen and Nikolaev (2017), I drop extremely short files containing less than 7,000 words. To reduce data contamination ${ }^{18}$, I only retain the files that contain the terms "credit agreement", "loan agreement", or "loan and security agreement" in the title (i.e., the first 3,072 characters of each Exhibit 10). ${ }^{19}$

To locate GAAP provisions in debt contracts, I randomly check 300 subsamples and find that GAAP provisions generally are located in paragraphs defining terms such as "GAAP", "Accounting Terms", “Accounting Determinations", "Accounting Matters", and "Accounting Changes". Then for each file in the search sample, I retain those paragraphs and manually delete irrelevant sentences to alleviate any concern that those sentences contain the keywords used to judge the type of GAAP provisions. Based on the description of GAAP provisions, I classify debt contracts into three categories: frozen-on-request GAAP, frozen GAAP, and floating GAAP (see examples in Appendix I). Specifically, I first manually code the 300 subsamples and identify common keywords to help me automatically categorize the type of GAAP provisions. Second, I use these keywords to automatically code a pilot sample of 700 debt contracts and revise keywords until I achieve an acceptably high degree of accuracy. ${ }^{20}$

\footnotetext{
${ }^{17}$ I also consider their lowercase and uppercase formats as well as their singular and plural formats.

${ }^{18}$ Without this requirement, data contamination could come from (1) the whole 10-K or 10-Q shown as Exhibit 10s without a private debt contract; (2) other types of material contracts that also satisfy the above requirements, such as omnibus agreements, guaranty, receivables sales agreements, and limited liability company membership purchase agreements; (3) duplicated contracts shown as commitment letters by lenders.

${ }^{19}$ I choose the first 3,072 characters to retain the first few lines rather than just the header, because in some special cases, without reading the description following the header, it is hard to judge the content of this file.

Although this procedure leads to a clean sample, it deletes debt contracts appearing in other parts except the beginning of Exhibit 10s. It is hard to extract those contracts from Exhibit 10 files.

${ }^{20}$ I manually code 1,000 debt contracts that include the previous 300 subsample and another pilot subsample of
} 
Third, I use the revised automated coding to classify the entire sample.

The resulting sample contains 24,026 debt contracts. After merging it with Compustat via CIK identifier, I am left with 18,923 contracts (i.e., the initial sample). ${ }^{21}$ My sample size is larger than that in Christensen and Nikolaev (2017) and those in studies using DealScan sample (e.g., Christensen and Nikolaev 2012). I delete loans with less than five-year maturity, mainly because these loans are less likely to experience GAAP changes relevant to covenants, weakening the role of GAAP provisions in debt contracts. ${ }^{22}$ To facilitate the data collection of debt contract characteristics, I manually match my initial sample to the facilities in DealScan and get a sample of 6,927 facilities outstanding to 2,144 public non-financial U.S firms. To ensure the accuracy of matching, I manually check whether the contracts' borrower, issuing date, effective date, loan types (i.e., revolving loan or term loan), loan amount, loan maturity, and lenders (i.e., lead arranger, administrative agent, syndication agent, documentation agent, and other lender roles if exist) in my sample are the same as those in the DealScan. ${ }^{23}$

I further require non-missing values of variables in the choice model of GAAP provision types. This requirement yields a final sample of 5,605 facilities for 1,716 borrowers. In this sample, 99 percent of borrower-initiation year observations have only one type of GAAP provision, and 84 percent of borrowers (i.e., 1,446 borrowers) have only one type of GAAP provision in my sample period, indicating that GAAP provision types are persistent over time

\footnotetext{
700 , and revise my automated coding until more than $85 \%$ of contracts coded by my automated coding have the same classification results as those coded manually. To the extant that some contracts are misclassified, this will bias me against finding results supporting my hypotheses.

${ }^{21}$ Following Christensen and Nikolaev (2017), my sample includes both new and amended debt contracts. As amended contracts already reflect ex post renegotiations, the likelihood of false positives and false negatives would be lower under amended agreements. Including those agreements causes a conservative bias.

${ }^{22} 51.18$ percent of facilities reported in DealScan have maturity more than five years (inclusive).

${ }^{23}$ Borrowers' identifier is matched using the DealScan-Compustat linking table shared by Chava and Roberts (2008).
} 
at the firm level, consistent with Christensen and Nikolaev (2017). ${ }^{24}$ Among the remaining 16 percent of borrowers (i.e., 274 borrowers), 184 borrowers change the type of GAAP provision from frozen or floating GAAP to frozen-on-request GAAP. ${ }^{25}$ Of my final sample of 5,605 facilities, 64 percent, 26 percent, and 10 percent have frozen-on-request GAAP, frozen GAAP, and floating GAAP, respectively. Among frozen GAAP, 62 percent have frozen GAAP with renegotiation and the rest have unconditionally frozen GAAP.

\subsection{Potential Self-Selection Issue}

Frozen-on-request GAAP is not randomly chosen from the three alternative GAAP provision types. A non-random sample would result in a biased estimation of the effect of frozen-on-request GAAP on false positives and false negatives (i.e., average treatment effect on the treated). To correct for this potential self-selection bias, I employ Heckman's (1979) selection model. ${ }^{26}$ First, I construct a determinant model of frozen-on-request GAAP based on borrowers' and lenders' relative negotiation power, the number of lenders and the number of lenders squared, borrowers' financial reporting complexity, and other determinants. The determinants I investigate are beyond those reported in the internet appendix of Christensen and Nikolaev (2017).

\subsubsection{Relative Negotiation Power}

\footnotetext{
${ }^{24}$ Therefore, I don't include firm fixed effects in Eq. (1).

${ }^{25}$ That means for a borrower, the maximum initiation date of debt contracts with frozen or floating GAAP (frozenon-request GAAP) is earlier than the minimum initiation date of debt contracts with frozen-on-request GAAP (frozen or floating GAAP). That means no time overlap.

I also check the classification of GAAP provision type for the 274 borrowers and find my classification is correct.

${ }^{26}$ Following Tucker (2010)'s suggestion, I use Heckman's (1979) selection model rather than propensity-score matching, because the selection bias could be due to unobservable and uncontrolled determinants of frozen-onrequest GAAP. I also do not use the regular IV procedure, because based on Larcker and Rusticus (2010)'s survey, the endogenous variable in the IV method is a continuous variable but in the selection model it is an indicator variable. In my setting, the endogenous variable, frozen-on-request GAAP, is an indicator variable and therefore I use selection models.
} 
Frozen-on-request GAAP is the outcome of borrowers' and lenders' relative negotiation power. As frozen-on-request GAAP is used to satisfy lenders' demands for accounting information, lenders prefer it to frozen and floating GAAP. This is supported by the frequency of frozen-on-request GAAP in contracts where Bank of America is the lead arranger. Bank of America is the top two largest lead arrangers in the private debt market (Ross 2010). In my regression sample of 5,605 facilities, 946 facilities have Bank of America as one of the lead arrangers. Of the 946 facilities, 701 have frozen-on-request GAAP provision, 174 have frozen GAAP provision, and the rest 71 have floating GAAP provision, indicating Bank of America's preference towards frozen-on-request GAAP.

However, in most cases, borrowers prefer floating GAAP because it is costly and difficult to keep multiple sets of accounting books in practice. Borrowers need to keep multiple sets if a GAAP change relevant to covenants occurs under frozen GAAP or if a GAAP change is rejected under frozen-on-request GAAP, but do not need to keep multiple sets under floating GAAP. Beatty et al. (2002) find that borrowers are willing to pay higher interest rates to avoid keeping multiple sets, suggesting borrowers' preference to floating GAAP.

Given the conflicting preferences of the two parties, the choice of frozen-on-request GAAP depends on their relative negotiation power. I use borrowers' size (Firm Size) and credit risk proxied by Credit Rating and No Rating to measure borrowers' negotiation power, and expect that borrowers with larger size and lower credit risk are less likely to use frozen-onrequest GAAP. I use Lender Reputation, an indicator variable equal to one if the lead arranger is one of the top ten lenders reported in Ross (2010), to capture lenders' negotiation power, and expect a positive association between lenders' reputation and the use of frozen-on-request 
GAAP.

\subsubsection{The Number of Lenders}

Frozen-on-request GAAP has advantages in reducing renegotiation costs. I measure renegotiation costs as the number of lenders (Num_Lender) because the coordination cost during the renegotiation process increases with the number of lenders (e.g., Bolton and Scharfstein 1996). I predict a positive relationship between the number of lenders and the use of frozen-on-request GAAP. However, when the number of lenders increases beyond a cutoff (e.g., the loan is traded in the secondary loan market), renegotiations would become too costly to commit and therefore the two parties prefer no renegotiation under frozen and floating GAAP. Note that when the two parties have conflicting preferences towards GAAP changes, they should enter into renegotiations under frozen-on-request GAAP but can reject renegotiations under frozen and floating GAAP. I control for the square of the number of lenders, Num_Lender_Sq, and anticipate that facilities with a larger square of the number of lenders are less likely to use frozen-on-request GAAP. In sum, I expect a concave relationship between the number of lenders and the use of frozen-on-request GAAP.

\subsubsection{Financial Complexity}

As mentioned above, borrowers need to keep multiple sets of accounting books if a GAAP change is rejected under frozen-on-request GAAP and keeping the multiple sets is costly and difficult especially for borrowers with complex financial reporting. Following You and Zhang (2009), I use the number of words in $10-\mathrm{Ks}$ as a proxy for financial complexity (Financial Complexity) and expect that borrowers with complex financial reporting are less likely to use frozen-on-request GAAP. 


\subsubsection{Other Determinants}

I control for borrowers' Conservatism because Beatty et al. (2008) find that borrowers with lower reporting conservatism are more likely to have covenant definition adjustments. As both covenant definition adjustments and frozen-on-request GAAP serve to satisfy lenders' demands for accounting information, I expect that borrowers with lower conservatism are also more likely to have frozen-on-request GAAP. Similarly, I control for Collateral and expect that when lenders are protected by collateral, frozen-on-request GAAP is less likely to be used. Num_Covenant (i.e., the number of financial covenants) is added as a proxy for the level of reliance on accounting and lenders are more likely to require the use of frozen-on-request GAAP when the reliance on accounting is high. I also control for the type of facility (Revolver). Following Lennox et al. (2012)'s suggestion, I identify an exogenous independent variable, Num_GAAP_Change (i.e., the number of GAAP changes in the year prior to contract initiation), which is validly included in the determinant model and excluded from the outcome model (i.e., exclusion restriction). This variable should affect the use of frozen-on-request GAAP but should not affect false positives and false negatives during the term of the contract because those GAAP changes have already been taken into consideration at contract initiation. ${ }^{27}$

In addition to these new determinants, I control for existing determinants used in prior studies. Following Christensen and Nikolaev (2017), I add borrowers' uncertainty in future prospects (Uncertainty), measured by $R \& D$, Volatility, and Tobin's $Q$, and expect that borrowers with higher uncertainty prefer floating GAAP to frozen-on-request GAAP, because

\footnotetext{
${ }^{27}$ Findings reported in Table 4 suggest that firms are more likely to use frozen-on-request GAAP when the number of GAAP changes in the previous year is high.
} 
these borrowers are more likely to suffer from the absence of existing GAAP treatment. ${ }^{28}$ Following Beatty et al. (2002), I add Loan/Asset (i.e., the ratio of loan amount to borrowers' total assets) and expect a positive relation between this ratio and the use of frozen-on-request GAAP because the protection provided via frozen-on-request GAAP becomes more important to both borrowers and lenders when the loan size relative to firm size is larger. To control for the FASB's objective shift from reliability to relevance, I include year fixed effects and expect that the shift can explain the increase in the use of frozen-on-request GAAP. See Appendix II for variable definitions.

\subsubsection{Determinant Model of Frozen-on-Request GAAP}

Considering the opposite signs of the determinants of floating and frozen GAAP, I conduct separate analyses for each pair-wise comparison, frozen-on-request GAAP versus frozen GAAP and frozen-on-request GAAP versus floating GAAP. One may argue that when the borrower and the lenders design GAAP provisions, there are three types available rather than just frozen-on-request GAAP versus frozen GAAP or frozen-on-request GAAP versus floating GAAP. To address this concern, I combine frozen and floating GAAP as non-frozenon-request GAAP and examine the determinants of frozen-on-request GAAP versus nonfrozen-on-request GAAP.

$$
\begin{aligned}
& \text { Frozen-on-Request GAAP } P_{j}=\beta_{0}+\beta_{1} \text { Firm Size }_{i t-1}+\beta_{2} \text { Credit Rating }_{i t-1}+\beta_{3} \text { No Rating }_{i t-1} \\
& +\beta_{4} \text { Lender Reputation }{ }_{j}+\beta_{5} N u m_{-} \text {Lender }_{j}+\beta_{6} N u m_{-} L \text { Lender_S } q_{j} \\
& +\beta_{7} \text { Financial Complexity }_{i t-1}+\beta_{8} \text { Conservatism }_{i t-1}+\beta_{9} \text { Collateral }_{j} \\
& +\beta_{10 N u m \_C o v e n a n t_{j}}+\beta_{11} \text { Revolver }_{j}+\beta_{12} \text { Uncertainty }_{i t-1} \\
& +\beta_{13}{\text { Loan } / \text { Asset }_{j}}+\beta_{14} \text { Num_GAAP_Change } \text { t-l }_{-}+\text {Year FE }+\varepsilon_{j}
\end{aligned}
$$

\footnotetext{
${ }^{28}$ In contrast to Christensen and Nikolaev (2017), Darrough and Deng (2017) argue that firms with high uncertainty such as in high-technology or highly-competitive industries are more likely to use frozen GAAP.

${ }^{29}$ In untabulated model, I also include borrowers' relative risk aversion by using the data of Brenner (2015) and $R O A$, and find that the coefficients on both are insignificant.
} 
In this probit regression, the subscript $i$ refers to a borrower, $j$ refers to a facility, and $t$ denotes the facility initiation year. I use the final sample of 5,605 facilities for 1,716 borrowers to estimate this Equation. Based on the coefficient estimates, I construct the Inverse Mills Ratio by dividing the standard normal density by the cumulative standard normal distribution, and then include it as an additional explanatory variable in the outcome model where the dependent variable is a continuous variable. If the dependent variable in the outcome model is a binary variable, I conduct a maximum likelihood estimation where the selection model is Eq. (1). ${ }^{30} \mathrm{I}$ winsorize all continuous variables at the $1^{\text {st }}$ and $99^{\text {th }}$ percentiles to correct for outliers.

\subsection{Measures of False Positives}

False positives mean covenant violations occur when borrowers' creditworthiness does not deteriorate. ${ }^{31}$ Following Demerjian et al. (2020), I use two metrics to measure false positives. First, I identify false positives as the situation where borrowers have positive abnormal stock returns in one preceding quarter and the concurrent quarter but report debt covenant violations in the concurrent quarter (False Positives_1). Second, as stock returns capture more than the changes in credit risk, I identify false positives as an alternative situation where borrowers have credit rating upgrades in the year prior to debt covenant violations (False Positives_2).Admittedly, given that credit rating upgrades are not frequent, the sample of False Positives_2 is small, reducing the power of my test. The data of debt covenant violations between June 1996 and March 2008 is from Nini, Smith, and Sufi (2012) who use a text-search

\footnotetext{
${ }^{30}$ Similar to the Heckman two-stage regression, the maximum-likelihood estimation (i.e., Heckprobit) also comprises a selection model and an outcome model, but there is no inverse mills ratio in the outcome model.

${ }^{31}$ One may argue that the covenant violation caused by accounting changes is a direct measure of false positives. However, it is difficult to identify this kind of covenant violation because in practice borrowers in most cases do not disclose the reasons for covenant violations. The exception is the violation of covenants restricting capital expenditure, a case where borrowers generally disclose the reasons.
} 
algorithm to obtain actual covenant violations from the SEC filings. ${ }^{32}$ Following the procedure prescribed in Nini et al. (2012), I collect debt covenant violation data over the period of January 2008 and December $2017 .{ }^{33}$ Specifically, I first use Python to search one of 20 terms (see Appendix III) in all $10-\mathrm{Ks}$ or $10-\mathrm{Qs}$ filed during this period, and retain the 10 lines before and after the term if the program finds a term. Then, I manually check these lines to ensure the existence of financial covenant violations in the reporting period of those filings. ${ }^{34}$

To test H1a using False Positives_1, I collect a sample of facilities identified in Eq. (1) that have positive stock returns in one preceding quarter and the concurrent quarter during the term of contracts. I then merge the sample with debt covenant violation data, resulting in 23,153 facility-year observations. ${ }^{35}$ After deleting borrowers having outstanding facilities with mixed GAAP provision types in a given year ${ }^{36}$, the sample size reduces to 21,026 observations. I further require non-missing values of independent variables, and I am left with 10,503 observations, of which 163 experience debt covenant violations (i.e., False Positives_l equals one).

Similarly, to test H1a using False Positives_2, I construct a sample of facilities identified in Eq. (1) that experience an upgrade of the Standard \& Poor's, Moody's, or Fitch

\footnotetext{
${ }^{32}$ The Regulatory S-X requires disclosure following a debt covenant violation regardless of whether a waiver is granted or not. SEC (2003) required that "companies that are, or are reasonable likely to be, in breach of such covenants must disclose material information about that breach and analyze the impact on the company if material".

33 The period of overlap between Nini et al. (2012)'s debt covenant violation data and mine allows me to compare data and ensure the accuracy of my covenant violation data.

${ }^{34}$ For the $10-\mathrm{K}$ filings, I check whether the covenant violations occur in the fourth quarter. In addition, if a borrower is during the "covenant holiday", a period when the borrower is not required to comply with financial covenants, I code such cases as covenant compliance.

${ }^{35}$ Here the year is determined based on the concurrent quarter.

${ }^{36}$ This sample requirement is to increase the power of the test. Firms don't disclose which facility they violate. That means the debt covenant violation data is at the firm level and therefore False Positive is also at the firm level. If one firm has multiple type of GAAP provision in one year, then I can not identify which type of GAAP provision is in the violated facility.
} 
ratings, and then merge with covenant violation data by requiring that the upgrade occurs in the preceding year of the violation, yielding 3,719 observations. I also require that borrowers have outstanding facilities with non-mixed GAAP provision types in a given year and have non-missing values of control variables. These requirements reduce my sample size to 1,700 observations. Of those observations, 52 experience debt covenant violations (i.e., False Positives_2 equals one).

I use maximum likelihood estimation where the determinant model is Eq. (1) to test the effect of frozen-on-request GAAP on false positives.

$$
\begin{aligned}
\text { False Positive }_{i t}= & \alpha_{1} \text { Frozen-on-Request GAAP }_{j t}+\alpha_{2} \text { Firm Size }_{i t}+\alpha_{3} \text { Leverage }_{i t}+\alpha_{4} \text { ROA }_{i t} \\
& +\alpha_{5} \text { Dividend }_{i t}+\alpha_{6} \text { Std_Cash Flows }{ }_{i t}+\alpha_{7} \text { Rating }_{i t}+\alpha_{8} \text { Covenant } \\
& \text { Tightness }_{j t}+\alpha_{9} \text { Collateral }_{j t}+\varepsilon_{i t}
\end{aligned}
$$

Where I control for factors that have been shown to affect false positives in Demerjian et al. (2020). These factors include Firm Size, Leverage, ROA, an indicator variable equal to one if a borrower pays dividends (Dividend), the standard deviation of annual operating cash flows in previous five years (Std_Cash Flows), Rating, Covenant Tightness, and Collateral. H1a predicts a negative coefficient on Frozen-on-Request GAAP. As the Heckman specification could underestimate the likelihood of rare events, I also employ the Penalized Maximum Likelihood Estimation (Firth 1993).

\subsection{Measure of False Negatives}

False negatives mean covenant violations do not occur when borrowers' creditworthiness deteriorates. ${ }^{37}$ My measure of false negatives is the instantaneous risk of a

\footnotetext{
${ }^{37}$ I don't use credit rating downgrades as creditworthiness deterioration because prior studies such as Cheng and Neamtiu (2009) find that credit rating downgrades lack timeliness. Lack of timeliness would reduce the number of months between credit rating downgrade and the first covenant violation following the downgrade, and therefore significantly hinders the ability of the number of months to capture false negatives. Credit rating upgrades also occur with a lag, but for my measure of false positives the timeliness issue is not as crucial as for the measure of false negatives because I use a broad window to measure false positives, and therefore I still use
} 
covenant violation (Num_Month) proposed by Zhang (2008). More specifically, if covenant violations occur, Num_Month equals the number of months between the first negative stock price shock defined as less than $-28 \%$ monthly abnormal return and the first covenant violation following the price shock. If no covenant violation occurs, Num_Month is the number of months between the first negative stock price shock and the sample ending or loan maturity. Considering the effect of financial crisis on stock returns, I adjust borrowers' monthly return by the value-weighted market return. The choice of $-28 \%$ as the cutoff is to identify negative stock price shocks that are two standard deviations lower than the mean. A smaller Num_Month implies that covenant violations occur in a timely manner and therefore false negatives are lower.

To test my hypothesis H1b, I collect a sample of facilities during the 1996 and 2017 period identified in Eq. (1), which experience at least one negative stock price shock between facility initiation dates and the sample ending date (or maturity dates). I identify the first negative stock price shock for each facility and then merge with covenant violation data to calculate Num_Month. I also require non-missing values of control variables. The above requirements yield a regression sample of 1,322 facilities from 552 borrowers. Of the 1,322 facilities, 387 report covenant violations subsequent to the first negative stock price shock. Using this sample, I estimate the following model:

$$
\begin{aligned}
\log \left(\text { Num_Month }_{j}\right)= & \alpha_{1} \text { Frozen-on-Request GAAP }_{j}+\alpha_{2} \text { Cumret }_{j}+\alpha_{3} \text { Firm Size }_{i}+\alpha_{4} \text { Leverage }_{i} \\
& +\alpha_{5} \text { ROA }_{i}+\alpha_{6} \text { Rating }_{i}+\alpha_{7} \text { Loan Size }_{j}+\alpha_{8} \text { Month_to_Maturity }_{j} \\
& +\alpha_{9} \text { Num_Covenant }_{j}+\alpha_{10} \text { Inverse Mills Ratio }_{j}+\text { Year FE }+\varepsilon_{j}
\end{aligned}
$$

where I control for cumulative negative stock returns (Cumret), Firm Size, Leverage, ROA, Rating, Loan Size, the number of months between the first negative stock price shock and loan 
maturity (Month_to_Maturity), and Num_Covenant. I include the Inverse Mills Ratio derived from Eq. (1) to correct for potential self-selection bias. H1b predicts a negative coefficient $\left(\alpha_{1}<0\right)$ for frozen-on-request GAAP (i.e., frozen-on-request GAAP decreases with the number of months).

\section{Main Results}

\subsection{Descriptive Statistics}

Table 2 presents the sample distribution by filing years of my initial sample (i.e., 18, 923 debt contracts in Column 1) and regression sample (i.e., 5,605 facilities in Column 2). In Column 1, the number of debt contracts filed before 2001 is smaller than the sample used in Christensen and Nikolaev (2017), because many debt contracts filed before 2001 are embedded in the SEC filings rather than as a separate Exhibit 10. The number of observations shrinks in 2017 because the update on the historical GVKEY-CIK Linking Table from WRDS SEC Analytics Suite lacks timeliness. ${ }^{38}$ Panels A, B, C and D of Table 3 present the descriptive statistics for the variables used in Eq. (1), (2) and (3). Specially, the descriptive statistics reported in Panel B and C for Eq. (2) are comparable to those of Demerjian et al. (2020). Also, the statistics reported in Panel D for Eq. (3) are comparable to the statistics of the negative stock price shock sample reported in Zhang (2008).

\subsection{Results for the Determinant Model}

Table 4 presents the results of the determinant model. To compare with prior studies, I first combine frozen-on-request GAAP with frozen GAAP in Column 1 to contrast frozen

\footnotetext{
${ }^{38}$ I downloaded the table on August 9th, 2018 when some borrowers' last date of Compustat Data hadn't been updated to 2017.
} 
GAAP broadly defined with floating GAAP. In this column, two of the three uncertainty measures, $R \& D$ and Volatility, are negatively associated with the probability of broad frozen GAAP, consistent with Christensen and Nikolaev (2017). Although the significantly positive coefficient on Tobin's $Q$ is not consistent with Christensen and Nikolaev (2017), it is consistent with the notion that firms in the growth stage tend to have a higher demand for debt capital and therefore have weaker negotiation power over the choice of GAAP provision types. As lenders prefer frozen-on-request GAAP, borrowers with higher Tobin's $Q$ are more likely to have frozen-on-request GAAP.

The next three columns of Table 4 report the results for the determinants of frozen-onrequest GAAP. Specifically, columns 2 and 3 show the results of pair-wise comparisons, frozen-on-request GAAP versus floating GAAP and frozen-on-request GAAP versus frozen GAAP. The significantly negative coefficient on Firm Size and significantly positive coefficients on Credit Rating and No Rating in Column 2 indicate borrowers' preference for floating GAAP. This is consistent with the survey result of Gopalakrishnan and Parkash (1995) that 73 percent of borrowers agree to use floating GAAP rather than frozen GAAP. The results in Column 3 can help distinguish frozen-on-request GAAP from frozen GAAP. Specifically, lenders with higher negotiation power (Lender Reputation), contracts with a larger number of lenders (Num_Lender), and borrowers facing higher uncertainty (Tobin's $Q$ and $R \& D$ ) are more likely to use frozen-on-request GAAP. However, contracts with collateral protection (Collateral) and borrowers with conservative financial reporting (Conservatism) are more likely to use frozen GAAP. Those results explain the different trends in the use of frozen-onrequest GAAP and frozen GAAP, extending the determinants reported in Christensen and 
Nikolaev (2017).

Column 4 reports the results of the determinants of frozen-on-request GAAP versus non-frozen-on-request GAAP. The coefficient on Lender Reputation is significantly positive, indicating that lenders prefer frozen-on-request GAAP to frozen and floating GAAP. ${ }^{39}$ The significantly positive coefficient on Num_Lender echoes the upward trend in syndicated loans and is consistent with frozen-on-request GAAP being preferable as renegotiation costs increase. However, Num_Lender_Sq is negatively associated with Frozen-on-Request GAAP, suggesting that when the number of lenders increases beyond a certain cutoff, the high renegotiation costs would hinder borrowers and lenders' willingness to renegotiate and as a result the two parties would prefer no renegotiation under frozen or floating GAAP. The significantly negative relationship between Financial Complexity and Frozen-on-Request GAAP is in line with my expectation that borrowers with complex financial reporting would bear higher costs of keeping multiple sets of accounting books and therefore are less likely to use frozen-on-request GAAP. In addition, when lenders are protected by borrowers' conservative financial reporting and collateral, they reduce their reliance on frozen-on-request GAAP evidenced as significantly negative coefficients on Conservatism and Collateral. These results help explain why some private debt contracts use frozen-on-request GAAP but others do not, above and beyond the determinants of GAAP provision types explored in prior studies.

\subsection{Results for Hypothesis H1}

Table 5 presents the results of the effect of frozen-on-request GAAP on false positives using the positive stock return sample (i.e., my first measure of false positives). I employ three

\footnotetext{
${ }^{39}$ The result is similar by coding Lender Reputation as an indicator variable equal to one if the lead arranger is one of the top three lenders reported in Ross (2010).
} 
methods to estimate the effect, the maximum likelihood estimation to control for potential selfselection bias (i.e., Heckman), the Penalized Maximum Likelihood Estimation method to correct for the likelihood of rare events (i.e., Firthlogit), and the ordinary probit regression as a robustness test of Heckman regression following the suggestion from Lennox et al. (2012). ${ }^{40}$ The benchmark in columns 1, 2, and 3 is floating GAAP, while in columns 4, 5, and 6 is frozen GAAP and in columns 7 to 9 is non-frozen-on-request GAAP. The significantly negative coefficients on Frozen-on-Request GAAP across the nine columns reflect that false positives are lower under frozen-on-request GAAP than under frozen and floating GAAP. Moreover, the Heckman results are economically meaningful in that contracts with frozen-on-request GAAP are 20.0\% (Column 1), 21.4\% (Column 4) and 25.4\% (Column 7) less likely to experience false positives than contracts with floating GAAP, frozen GAAP, and non-frozen-on-request GAAP, respectively. ${ }^{41}$ Also, the significant and negative coefficients on Firm Size, ROA and Dividend and the significantly positive coefficients on Collateral and Covenant Tightness suggest that larger, more profitable, and dividend paying borrowers and debt contracts with less tight covenants and no collateral are less likely to experience false positives.

Table 6 reports the results of the effect of frozen-on-request GAAP on false positives using the credit rating upgrade sample (i.e., my second measure of false positives). As shown in columns 1 to 9 , false positives are significantly lower under frozen-on-request GAAP than under floating GAAP, frozen GAAP, and non-frozen-on-request GAAP. With respect to the economic significance of the Heckman results, I find that contracts with frozen-on-request

\footnotetext{
${ }^{40}$ Among the three methods, the maximum likelihood estimation is the best in this setting because it corrects for the potential self-selection issue which could bias my results.

${ }^{41}$ I use the marginal effect to evaluate the economic significance.
} 
GAAP are $18.3 \%$ (Column 1), 29.7\% (Column 4), and 24.6\% (Column 7) less likely to experience false positives relative to contracts with floating GAAP, frozen GAAP, and nonfrozen-on-request GAAP, respectively. The significant and negative coefficients on Firm Size and Dividend are consistent with the results in Demerjian et al. (2020), and the significantly positive coefficients on Covenant Tightness imply that borrowers with tighter covenants are more likely to experience false positives. Taken together, the results reported in tables 5 and 6 support H1a that false positives are lower under frozen-on-request GAAP than under frozen and floating GAAP.

I next highlight the regression results of the effect of frozen-on-request GAAP on false negatives in Table 7. In columns 1 to 6, I take the log of Num_Month as the dependent variable and use both the Heckman two-stage regression and OLS regression because OLS is more robust than the Heckman two-stage regression (Lennox et al. 2012). ${ }^{42}$ I find that the coefficients on Frozen-on-Request GAAP are significantly negative in Column 1 (-0.252, p=0.002), Column $3(-0.149, \mathrm{p}=0.013)$, and Column $5(-0.152, \mathrm{p}=0.005)$, indicating lower false negatives under frozen-on-request GAAP. Specifically, the coefficients suggest that the number of months in contracts with frozen-on-request GAAP decreases by $25.2 \%, 14.9 \%$, and $15.2 \%$ relative to in contracts with floating GAAP, frozen GAAP, and non-frozen-on-request GAAP, respectively. In addition, the negative coefficients on Cumret, Leverage and Month-to-Maturity, and the positive coefficients on Firm Size, ROA and Rating are consistent with Zhang (2008). The significant coefficient on Inverse Mills Ratio in Column 5 suggests that the correction for

\footnotetext{
${ }^{42}$ Lennox et al. (2012) find that OLS is more robust than Heckman selection model because it does not have exclusion restrictions and has low multicollinearity.
} 
selection bias is significant in the model.

In columns 7 to 9, I replace $\log \left(N u m_{-}\right.$Month) by Num_Month, a count variable, as the dependent variable and employ the Poisson regression. The coefficients on Frozen-on-Request GAAP remain significantly negative. In sum, the results in Table 7 supports my $\mathrm{H} 1 \mathrm{~b}$ that false negatives are lower for debt contracts with frozen-on-request GAAP than for contracts with frozen and floating GAAP.

\subsection{Results for Hypothesis $\mathrm{H} 2$}

To test the effect of variation in standard setting activity, I review all major standards over my sample period and select fifteen SFAS as the most relevant standards to financial covenants (see Table 8) based on the following criteria. First, SFAS should not be about changes to disclosures only, such as SFAS 131 and 132, or for financial industries such as SFAS 134 and 138. Second, SFAS should materially affect the definitions of financial covenants. ${ }^{43}$ For example, I exclude SFAS 128 (Earnings per Share) because performance covenants are not based on EPS. Third, it must be feasible to identify affected firms. For example, I exclude SFAS 133 and 137 (Accounting for Derivative Instruments and Hedging Activities) as I am unable to identify nonfinancial firms with derivative instruments around the effective date of June 15 , 2000. I use SFAS rather than FASB updates for two reasons. First, an update may not have the power to significantly affect financial covenants. Second, the high frequency of updates issuance evidenced by the 16.7 accounting updates per year on average from 2009 to 2018 increases the difficulty to get rid of potential confounding events.

\footnotetext{
${ }^{43}$ I include SFAS 123 (Accounting for Stock-Based Compensation) that introduces a fair value-based method of accounting for stock-based compensation but allows the continued use of intrinsic value-based method if firms make pro forma disclosures of net income. In the untabulated analysis, I find similar results to those of Table 9 if I exclude SFAS 123.
} 
For each of the fifteen SFAS, I identify the effective date and establish criteria to select affected firms. The criteria to select affected firms follow Khan, Li, Rajgopal, and Venkatachalam (2018), except the criteria for SFAS 157 and 159 because the banking industry which is the base of affected firms in their study is excluded in my paper. To test the effect of the fifteen SFAS on false positives and false negatives, I regard the three years prior to each effective date as the pre-treatment period and the three years subsequent to each effective date as the post-treatment period. ${ }^{44}$ The time restriction is to mitigate the concern on confounding events. I compare false positives and false negatives in the pre- versus post-treatment periods and I expect lower false positives and false negatives in the post-treatment period.

Table 9 presents the results of the effect of the fifteen SFAS. The dependent variable in columns 1 and 2 is False Positives_1, in columns 3 and 4 is False Positives_2, and in columns 5 and 6 is $\log ($ Num_Month). Columns 1, 3 and 5 report the effect of frozen-on-request GAAP on false positives and false negatives in the pre-treatment period and columns 2, 4 and 6 report the effect in the post-treatment period. I use the Heckman specification and find that the coefficients on Frozen-on-Request GAAP are not significant in two of the three tests in the pretreatment period but highly significant for all three in the post-treatment period. ${ }^{45}$ Collectively, Table 9 provides systematic evidence for $\mathrm{H} 2 \mathrm{a}$ and $\mathrm{H} 2 \mathrm{~b}$ that the reductions in false positives

\footnotetext{
${ }^{44}$ For Num_Month, I require that the first negative shock (i.e., the start point of the time interval) should occur in the three years subsequent to the effective date in the post-period, but I do not impose an equivalent restriction in the pre-period. This is because the effective dates of the 15 SFAS spanned from 1995 to 2008 and I focus on debt contracts with more than five-year maturity. As a result, if I require that the first covenant violation or the maturity (i.e., the end point of the time interval) should occur in the three years prior to the effective date in the pre-period, my sample size in the pre-period would be only 195. The result using the 195 observations (untabulated) is quantitatively similar to the result without imposing such restriction in the pre-period.

${ }^{45}$ If a firm-year is in both the pre- and post-period samples, then this would weaken the power of my tests. Therefore, I use a sample of unique firm-year-post observations (i.e., for a firm-year, if the count of Post equal to one is larger than the count of Post equal to zero, then I delete the observations in the pre-period and otherwise delete the observations in the post-period to keep my sample size as large as possible) and get similar results.
} 
and false negatives under frozen-on-request GAAP are more pronounced during periods of significant accounting changes relevant to financial covenants.

\subsection{Results for Hypothesis $\mathrm{H3}$}

To explore frozen-on-request GAAP's advantages in reducing renegotiation costs and facilitating renegotiations, I split frozen-on-request GAAP into GAAP with renegotiation and GAAP without renegotiation, and examine the effect on false positives and false negatives by using a sample of frozen-on-request GAAP with renegotiation versus non-frozen-on-request GAAP and a sample of frozen-on-request GAAP without renegotiation versus non-frozen-onrequest GAAP. Table 10 presents the results. The coefficients on Frozen-on-Request GAAP are significantly negatives in columns 2 and 4 where I compare frozen-on-request GAAP without renegotiation to non-frozen-on-request GAAP. However, the coefficients are insignificantly negative in Column 1 and insignificantly positive in Column 3 where I compare frozen-onrequest GAAP with renegotiation to non-frozen-on-request GAAP. The results suggest that compared to frozen-on-request GAAP with renegotiation, frozen-on-request GAAP without renegotiation is more useful in reducing false positives, supporting frozen-on-request GAAP's advantage in reducing renegotiation costs. For the results of false negatives, the coefficient on Frozen-on-Request GAAP is more negative in Column 5 where I compare frozen-on-request GAAP with renegotiation to non-frozen-on-request GAAP than the coefficient in Column 6. The results indicate that frozen-on-request GAAP with renegotiation is more useful in reducing false negatives and support frozen-on-request GAAP's advantage in facilitating renegotiations. Taken together, these results highlight the role of reduced renegotiation costs and renegotiation facilitating in improving debt contracting efficiency and support my $\mathrm{H} 3 \mathrm{a}$ and $\mathrm{H} 3 \mathrm{~b}$. 


\section{Additional Analyses}

\subsection{When Is Frozen-on-Request GAAP Less Useful?}

\subsubsection{The Effect of Financial Crisis on False Positives}

In hypotheses $\mathrm{H} 1 \mathrm{a}$ and $\mathrm{H} 1 \mathrm{~b}, \mathrm{I}$ assume that lenders care more about debt contracting efficiency of GAAP changes and borrowers care more about the effect of GAAP changes on covenant tightness. The assumption relating to lenders may not hold during the financial crisis when the banking industry's regulatory capital increases. Anecdotal evidence shows that to increase capital, banks will care more about covenant tightness and push borrowers into covenant violations to trigger renegotiations to obtain favorable contract terms such as higher interest rates and shorter maturity. ${ }^{46}$ That suggests the reduction in false positives under frozenon-request GAAP may become weaker or even disappear during the financial crisis.

To test this expectation, I employ the Heckman specification and estimate Eq. (2) during the 2007-2008 financial crisis and in the remaining sample period, separately. As credit rating upgrades during the financial crisis are rare, I only use the positive stock return sample (i.e., the first measure of false positives). Table 11 presents the results. The coefficients on Frozenon-Request GAAP are negative but insignificant over 2007-2008 and are significantly negative in other years, consistent with my expectation.

\subsubsection{Conflicting Preferences towards GAAP Changes - SFAS 159}

When borrowers and lenders have conflicting preferences, under frozen-on-request GAAP borrowers may reject GAAP changes beneficial to contracting efficiency but tightening

\footnotetext{
${ }^{46}$ https://www.cfo.com/banking-capital-markets/2009/06/tripped-up/
} 
covenants before renegotiations and may abuse renegotiations to push lenders to agree to reject these GAAP changes. As a result, frozen-on-request GAAP may not be more useful. To provide empirical evidence on this expectation, I use SFAS 159 as the research event given the debate around the standard's usefulness. Demerjian et al. (2016) find that this GAAP change is more likely to be incorporated into covenant calculations when it is informative of borrowers' hedging activities and liquidity value and is less likely to be incorporated when borrowers have unreliable fair value measure.

Following Demerjian et al. (2016), I construct a measure to capture where fair values are less likely to be reliable. Unreliable fair value measure (Unreliable FV) is an indicator variable equal to one if the borrower's ratio of Level 2 and 3 assets and liabilities to total financial assets and liabilities reported in the first fiscal year that begins after November 15, 2007 is higher than the median value. I assume that when borrowers have less reliable fair values (i.e., Unreliable $F V=1$ ), they prefer to adopt SFAS 159 but lenders prefer not to; but when borrowers have reliable fair values (i.e., Unreliable $F V=0$ ), both prefer the adoption. I use a sample of firms reporting any financial assets and liabilities in the first fiscal year after the adoption of SFAS 159, and expect reductions in false positives and false negatives in the three years after the adoption under frozen-on-request GAAP when borrowers have reliable fair value measure.

Table 12 reports the results of the effect of borrowers' and lenders' conflicting preferences towards GAAP changes in the setting of SFAS 159. The significantly negative coefficients on Frozen-on-Request GAAP in columns 2 and 4 where borrowers have more reliable fair value and the insignificant coefficients in columns 1 and 3 where borrowers have 
less reliable fair value support my expectation that frozen-on-request GAAP is more useful in reducing false positives when borrowers and lenders have the same preference. For the results of false negatives, the coefficient in Column 6 is negative but insignificant and in Column 5 is insignificantly positive. The weak results may be caused by the small number of observations for my false negatives sample.

\subsection{The Effect of Frozen-on-Request GAAP on Cost of Debt Capital}

Agency theory (e.g., Ahmed, Billings, Morton, and Stanford-Harris 2002; WittenbergMoerman 2008) suggests that reduced agency and information problems improve debt contracting efficiency, measured by cost of debt capital in empirical studies. In contrast to these studies, I formulate my hypotheses based on incomplete contracting theory and measure efficiency as the minimum of false positives and false negatives. My rationale for this decision is three-fold. First, the mechanism through which frozen-on-request GAAP is more efficient in addressing the impact of evolving GAAP on debt covenants is to reduce false positives and false negatives. Second, covenants may become ex post inefficient when accounting changes affect covenant calculations and false positives and false negatives can capture the ex-post inefficiency. However, cost of debt capital is an ex-ante measure of efficiency and therefore fails to capture the effect of frozen-on-request GAAP on covenants' ex-post efficiency. Third, "regardless of efficiency issues, debt holders would always be willing to accept a lower interest rate in return for more frequent transfer of decision rights to them" (Gigler et al. 2009, page 770), indicating that the low cost of capital may not be a result of efficiency.

However, considering the common use of cost of debt capital as a measure of debt contracting efficiency in empirical studies, I also estimate the effect of frozen-on-request 
GAAP on loan spreads for the comparability with previous studies. I use a sample of 5,605 facilities and construct Eq. (4) by augmenting the model used in Ahmed et al. (2002) and Wittenberg-Moerman (2008).

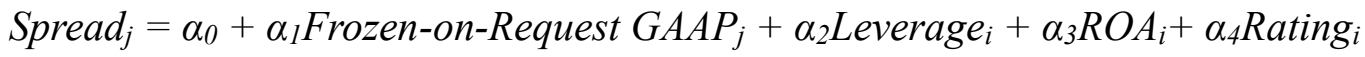

$$
\begin{aligned}
& +\alpha_{5} \text { Loan/Asset }_{j}+\alpha_{6} \text { Maturity }_{j}+\alpha_{7} \text { Revolver }_{j}+\alpha_{8} \text { Num_Covenant }_{j}
\end{aligned}
$$

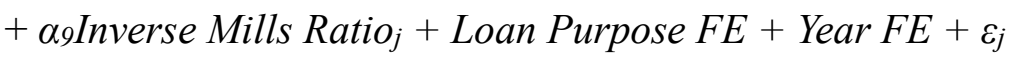

Table 2 Panel E presents the descriptive statistics of the regression variables. Table 13 reports the results of the effect of frozen-on-request GAAP on loan spreads using the Heckman regression and the OLS regression. I find significantly lower spreads under frozen-on-request GAAP compared to non-frozen-on-request GAAP, indicating that frozen-on-request GAAP enhances debt contracting efficiency as evidenced by lower loan spreads. Although I use a different definition and different measures of debt contracting efficiency, this table provides additional supports for my primary findings.

\subsection{Alternative Measure of False Positives}

Shareholders have incentives to enrich themselves as the expense of debtholders and as a response, debtholders seek to protect themselves via covenants. ${ }^{47}$ Under the shareholderdebtholder conflict, the positive abnormal stock return combined with a covenant violation may be a true covenant violation rather than a false positive. ${ }^{48}$ Using credit rating upgrades to reflect changes in credit risk is also problematic because credit ratings lack timeliness (Cheng and Neamtiu 2009). To mitigate these concerns, I construct a new measure by using bond returns to capture borrowers' creditworthiness and identifying false positives as borrowers who have

\footnotetext{
${ }^{47}$ Cascino (2017) find that stock-bond return co-movement is stronger when there are covenants in debt contracts. 48 The concern of shareholder-bondholder conflict is mitigated for false negatives because the simultaneous occurrence of increasing bond returns and decreasing stock returns is mainly caused by macroeconomic factors such economic slowdowns.
} 
positive bond returns in two consecutive quarters but report covenant violations in the concurrent quarter (i.e., False Positives_3). Bond returns pertain to debt and capture the changes in borrowers' creditworthiness in a timely manner. By proposing this new measure of false positives, my paper also extends Demerjian et al. (2020).

For False Positives_3, I collect bond trading data from the TRACE database, follow the procedure in Dick-Nielsen (2009) to clean the data, and exclude canceled, corrected, and reverse trades. To calculate quarterly bond returns, I first compute the quarter-end bond price as the trade-volume weighted average of prices in the last trading day of the quarter. Using this quarter-end price and the method in Jostova, Nikolova, Philipov, and Stahel (2013), I estimate quarterly bond returns as the ratio of the difference between the sum of quarter-end price, accrued interest and coupon paid during the quarter and the sum of lagged quarter-end price and lagged accrued interest to the sum of lagged quarter-end price and lagged accrued interest. For a borrower with more than one outstanding bonds in the quarter, I treat the borrower as a portfolio and calculate the value-weighted average of bond returns, following the suggestion of Bessembinder, Kahle, Maxwell, and Xu (2009). Using the bond returns data, I first validate bond returns as a proxy for borrowers' creditworthiness by demonstrating the relation between bond returns and credit rating downgrades. In particular, I sort the sum of bond returns in one preceding quarter and the concurrent quarter by decile, and then show the frequency of downgrades in the quarter following the concurrent quarter. As shown in Figure 5, 23.20\% of borrower-quarter observations in the bottom decile experience credit rating downgrades in the following quarter while only $8.47 \%$ in the top decile have downgrades. The difference in the frequency of downgrades between the top and bottom deciles is statistically significant with t- 
value of 16.219 , consistent with the notion in existing literature that bond returns capture changes in creditworthiness.

To measure false positives, I require positive bond returns in two consecutive quarters. After merging with my covenant violation data and control variable data, I am left with a sample of 10,059 borrower-quarter observations. However, only 94 observations in the sample experience debt covenant violations, suggesting that false positives captured by bond returns are also a rare event. Table 14 reports the regression results of the alternative measure. The coefficients on Frozen-on-Request GAAP in the Heckman, Firthlogit and probit regressions remain significantly negative, supporting my primary results that frozen-on-request GAAP reduces false positives.

\section{Conclusions}

This study focuses on the GAAP provisions that specify the treatment of GAAP changes in debt contracts. By collecting a sample of 18,923 private debt contracts issued from 1994 to 2017, I report an increase and current dominance of frozen-on-request GAAP, an underresearched type of GAAP provisions relative to frozen and floating GAAP. Motivated by its significant increase, I explore whether frozen-on-request GAAP is more useful in dealing with the impact of GAAP changes on covenant calculations than frozen and floating GAAP. To mitigate the concern on self-selection bias from the choice of GAAP provision types, I employ Heckman's (1979) selection model.

In the determinant model of frozen-on-request GAAP, I find that lenders with higher reputation are more likely to use frozen-on-request GAAP, suggesting their preference towards 
frozen-on-request GAAP; that borrowers with larger size and lower credit risk are more likely to use floating GAAP; that borrowers with more complex financial reporting are less likely to use frozen-on-request GAAP, implying that the cost of keeping multiple sets of accounting books is an important consideration when choosing the type of GAAP provisions; and that the renegotiation costs also matter evidenced by the concave relation between the number of lenders and the use of frozen-on-request GAAP.

In the outcome model, I use false positives (i.e., Type I error of covenant violations) and false negatives (i.e., Type II error of covenant violations) to measure the effect of GAAP provision on covenant calculations. I find lower false positives and false negatives under frozen-on-request GAAP after controlling for self-selection bias, suggesting that compared to frozen and floating GAAP, frozen-on-request GAAP is more useful in solving the impact of GAAP changes and therefore improving debt contracting efficiency. I also find that the reductions in false positives and false negatives under frozen-on-request GAAP are more evident when significant accounting changes relevant to financial covenants occur and when compared with unconditionally frozen GAAP, consistent with its advantages in incorporating and excluding GAAP changes and in reducing renegotiation costs.

An important caveat in interpreting my results is that I use only debt contracts with maturities of more than five years as my regression samples. As GAAP changes could be rationally anticipated by borrowers and lenders at the initiation of short-term debt contracts, my results may not be generalizable to short-term debt contracts. Another important limitation is the difficulty to collect the post-initiation data on frozen-on-request GAAP such as who requests a freeze. 


\section{REFERENCES}

Aghion P., and P Bolton. 1992. An incomplete contracts approach to financial contracting. The Review of Economic Studies 59: 473-494.

Ahmed A S., B K. Billings, R M. Morton, and M Stanford-Harris. 2002. The role of accounting conservatism in mitigating bondholder-shareholder conflicts over dividend policy and in reducing debt costs. The Accounting Review 77: 867-890.

Allen A., and K Ramanna. 2013. Towards an understanding of the role of standard setters in standard setting. Journal of Accounting and Economics 55: 66-90.

Armstrong C S., W R. Guay, and J P. Weber. 2010. The role of information and financial reporting in corporate governance and debt contracting. Journal of Accounting and Economics 50: 179-234.

Ball R., A Robin, and G Sadka. 2008. Is financial reporting shaped by equity markets or by debt markets? An international study of timeliness and conservatism. Review of Accounting Studies 13: 168-205.

Bao Y., B Ke, B Li, Y. J Yu, and J Zhang. 2020. Detecting accounting fraud in publicly traded U.S. firms using a machine learning approach. Journal of Accounting Research 58: 199235.

Barth M E., L D. Hodder, and S R. Stubben. Fair value accounting for liabilities and own credit risk. The Accounting Review 83: 629-664.

Beatty A., L Cheng, and T Zach. 2019. Nonrecurring items in debt contracts. Contemporary Accounting Research 36: 139-167.

Beatty A., K Ramesh, and J Weber. 2002. The importance of accounting changes in debt contracts: the cost of flexibility in covenant calculations. Journal of Accounting and Economics 33: 205-227.

Beatty A., J Weber, and J J Yu. 2008. Conservatism and debt. Journal of Accounting and Economics 45: 154-174.

Beatty A., and J Weber. 2006. Accounting discretion in fair value estimates: An examination of SFAS 142 goodwill impairments. Journal of Accounting and Economics 44: 257-288.

Belsley D., E. Kuh, and E R. Welsch. 1980. Regression diagnostics: Identifying influential data and sources of collinearity. New York, NY: Wiley and Sons.

Bessembinder H., K M. Kahle, W F. Maxwell, and D Xu. 2009. Measuring abnormal bond performance. The Review of Financial Studies 22: 4219-4258.

Bolton P., and D S. Scharfstein. 1996. Optimal debt structure and the number of creditors. Journal of Political Economy 104: 1-25.

Brenner S. 2015. The risk preferences of U.S. executives. Management Science 61: 1197-1471.

Bris A., and I Welch. 2005. The optimal concentration of creditors. The Journal of Finance 60: 2193-2212.

Cascino S. 2017. Stock-bond return co-movement and accounting information. Journal of Business Finance and Accounting. 44: 1036-1072.

Caskey J., and J S. Hughes. 2012. Assessing the impact of alternative fair value measures on the efficiency of project selection and continuation. The Accounting Review 87: 483-512.

Chava S., and M R. Roberts. 2008. How does financing impact investment? The role of debt covenants. The Journal of Finance 63: 2085-2121. 
Cheng M., and M Neamtiu. 2009. An empirical analysis of changes in credit rating properties: Timeliness, accuracy and volatility. Journal of Accounting and Economics 47: 108-130.

Christensen H B., and V V. Nikolaev. 2012. Capital versus performance covenants in debt contracts. Journal of Accounting Research 50: 75-116.

Christensen H B. and V V. Nikolaev. 2017. Contracting on GAAP changes: large sample evidence. Journal of Accounting Research 55: 1021-1050.

Christensen H B., V V. Nikolaev, and R Wittenberg-Moerman. 2016. Accounting information in financial contracting: the incomplete contract theory perspective. Journal of Accounting Research 54: 397-435.

Cohen M., S Katz, S Mutlu, and G Sadka. 2019. Do debt covenants constrain borrowings prior to violation? Evidence from SFAS 160. The Accounting Review 94: 133-156.

Darrough M., and M Deng. 2017. Accounting changes, asset substitution, and debt contracting. Working paper.

Demerjian P R. 2011. Accounting standards and debt covenants: Has the "balance sheet approach" led to a decline in the use of balance sheet covenants? Journal of Accounting and Economics 52: 178-202.

Demerjian P R., and E L. Owens. 2016. Measuring the probability of financial covenant violation in private debt contracts. Journal of Accounting and Economics 61: 433-447.

Demerjian P R., J Donovan, and C R. Larson. 2016. Fair value accounting and debt contracting: evidence from adoption of SFAS 159. Journal of Accounting Research 54: 1041-1076.

Demerjian P., J Donovan, and M F. Lewis-Western. 2020. Income smoothing and the usefulness of earnings for monitoring in debt contracting. Contemporary Accounting Research forthcoming.

Denis D J., and J Wang. 2014. Debt covenant renegotiations and creditor control rights. Journal of Financial Economics 113: 348-367.

Dick-Nielsen J. 2009. Liquidity biases in trace. Journal of Fixed Income 19: 43-55.

Donelson D C., R Jennings, and J Mcinnis. 2017. Financial statement quality and debt contracting: evidence from a survey of commercial lenders. Contemporary Accounting Research 34: 2051-2093.

Dyreng S D., R Vashishtha, and J Weber. 2017. Direct evidence on the informational properties of earnings in loan contracts. Journal of Accounting Research 55: 371-406.

EL-Gazzar S., and V Pastena. 1990. Negotiated accounting rules in private financial contracts. Journal of Accounting and Economics 12: 381-396.

Firth D. 1993. Bias reduction of maximum likelihood estimates. Biometrika 80: 27-38.

Frankel R, C Seethamraju, and T Zach. 2008. GAAP goodwill and debt contracting efficiency: evidence from net-worth covenants. Review of Accounting Studies 13: 87-118.

Gigler F, C Kanodia, H Sapra, and R Venugopalan. 2009. Accounting conservatism and the efficiency of debt contracts. Journal of Accounting Research 47: 767-797.

Givoly D., C Hayn, and S Katz. 2017. The changing relevance of accounting information to debt holders over time. Review of Accounting Studies 22: 64-108.

Gopalakrishnan V., and M Parkash. 1995. Borrower and lender perceptions of accounting information in corporate lending agreements. Accounting Horizons 9: 13-26.

Grossman S J., and O D. Hart. 1986. The costs and benefits of ownership: a theory of vertical and lateral integration. Journal of Political Economy 94: 691-719. 
Heckman J J. 1979. Sample selection bias as a specification error. Econometrica 47: 153-161. Huberman G., and C Kahn. 1988. Limited contract enforcement and strategic renegotiation. The American Economic Review 78: 471-484.

Jostova G., S Nikolova, A Philipov, and C W. Stahel. 2013. Momentum in corporate bond returns. The Review of Financial Studies 26: 1649-1693.

Khan M., and R L. Watts. 2009. Estimation and empirical properties of a firm-year measure of accounting conservatism. Journal of Accounting and Economics 48: 132-150.

Khan U., B Li, S Rajgopal, and M Venkatachalam. 2018. Do the FASB's standards add shareholder value? The Accounting Review 93: 209-247.

Kim I., and D J. Skinner. 2012. Measuring securities litigation risk. Journal of Accounting and Economics 53: 290-310.

Klein B., R G. Crawford, and A A. Alchian. 1978. Vertical integration, appropriable rents, and the competitive contracting process. The Journal of Law and Economics 21: 297-326.

Kothari S. P., K Ramanna, and D J. Skinner. 2010. Implications for GAAP from an analysis of positive research in accounting. Journal of Accounting and Economics 50: 246-286.

Larcker D F., and T O. Rusticus. 2010. On the use of instrumental variables in accounting research. Journal of Accounting and Economics 49: 186-205.

Leftwich R. 1983. Accounting information in private markets: evidence from private lending agreements. The Accounting Review 58: 23-42.

Lennox C S., J R. Francis, and Z Wang. 2012. Selection models in accounting research. The Accounting Review 87: 589-616.

Li J. 2013. Accounting conservatism and debt contracts: Efficient liquidation and covenant renegotiation. Contemporary Accounting Research 30: 1082-1098.

Li N. 2010. Negotiated measurement rules in debt contracts. Journal of Accounting Research 48: 1103-1144.

Li N. 2016. Performance measures in earnings-based financial covenants in debt contracts. Journal of Accounting Research 54: 1149-1186.

Mohrman M B. 1993. Debt contracts and FAS No. 19: A test of the debt covenant hypothesis. The Accounting Review 68: 273-288.

Mohrman M B. 1996. The use of fixed GAAP provisions in debt contracts. Accounting Horizons 10: 78-91.

Nikolaev V V. 2010. Debt covenants and accounting conservatism. Journal of Accounting Research 48: 137-176.

Nini G., D C. Smith, and A Sufi. 2012. Creditor control rights, corporate governance, and firm value. The Review of Financial Studies 25: 1713-1761.

Roberts M R., and A Sufi. 2009. Renegotiation of financial contracts: evidence from private credit agreement. Journal of Financial Economics 93: 159-184.

Rogerson W. 1992. Contractual solutions to the hold-up problem. The Review of Economics Studies 59: 777-793.

Ross D G. 2010. The "dominant bank effect": How high lender reputation affects the information content and terms of bank loans. The Review of Financial Studies 23: 27302756.

Saavedra D. 2018. Syndicate size and the choice of covenants in debt contracts. The Accounting Review 93: 301-329. 
Smith C W., and J B. Warner. 1979. On financial contracting: An analysis of bond covenants. Journal of Financial Economics 7: 117-161.

Sweeney A P. 1994. Debt-covenant violations and managers' accounting responses. Journal of Accounting and Economics 17: 281-308.

Tucker, J W. 2010. Selection bias and econometric remedies in accounting and finance research. Journal of Accounting Literature 29: 31-57.

Watts RL. 2003. Conservatism in Accounting Part I: Explanations and Implications. Accounting Horizons 17: 207-221.

Watts RL. 2006. What has the invisible hand achieved? Working Paper.

Watts RL., and JL Zimmerman. 1978. Towards a positive theory of the determination of accounting standards. The Accounting Review 53: 112-134.

Watts RL., and JL Zimmerman. 1979. The demand for and supply of accounting theories: The market for excuses. The Accounting Review 54: 273-305.

Watts RL., and JL Zimmerman. 1990. Positive accounting theory: a ten year perspective. The Accounting Review 65: 131-156.

Wittenberg-Moerman R. 2008. The role of information asymmetry and financial reporting quality in debt trading: evidence from the secondary loan market. Journal of Accounting and Economics 46: 240-260.

You H., and X Zhang. 2009. Financial reporting complexity and investor underreaction to 10$\mathrm{K}$ information. Review of Accounting Studies 14: 559-586.

Zhang J. 2008. The contracting benefits of accounting conservatism to lenders and borrowers. Journal of Accounting and Economics 45: 27-54. 


\section{Appendix I \\ Examples of Contracting Practices}

Example 1 Frozen-on-request GAAP provision with renegotiation.

A credit agreement of Abbott Laboratories dated as of December 13, 2016.

Accounting Terms. Except as otherwise expressly provided herein, all accounting terms not specifically defined herein shall be construed in accordance with, and all financial data (including financial calculations) required to be submitted pursuant to this Agreement shall be prepared in conformity with, generally accepted accounting principles as in effect in the United States from time to time ("GAAP"). If at any time any change in GAAP would affect the calculation of any covenant set forth herein and either the Borrower or the Required Lenders shall so request, the Administrative Agent, the Lenders and the Borrower shall negotiate in good faith to amend such covenant to preserve the original intent thereof in light of such change in GAAP (subject to the approval of the Required Lenders); provided that, until so amended, (i) such covenant shall continue to be calculated in accordance with GAAP prior to such change and (ii) the Borrower shall provide to the Administrative Agent and the Lenders, concurrently with the delivery of any financial statements or reports with respect to such covenant, statements setting forth a reconciliation between calculations of such covenant made before and after giving effect to such change in GAAP.

Example 2 Frozen-on-request GAAP provision without renegotiation. ${ }^{49}$

A credit agreement of Signal Peak Energy, LLC. dated as of October 22, 2010.

GAAP means generally accepted accounting principles in the United States of America.

Accounting Terms GAAP. Except as otherwise expressly provided herein, all terms of an accounting or financial nature shall be construed in accordance with GAAP, as in effect from time to time provided that, if the Borrowers notify the Administrative Agent that the Borrowers request an amendment to any provision hereof to eliminate the effect of any change occurring after the date hereof in GAAP or in the application thereof on the operation of such provision (including the effects of the application or discontinuance of the application of accounting for the effects of regulation to all or any portion of either Borrowers operations), or if the Administrative Agent notifies the Borrowers that the Required Lenders request an amendment to any provision hereof for such purpose, regardless of whether any such notice is given before or after such change in GAAP or in the application thereof, then such provision shall be interpreted on the basis of GAAP as in effect and applied immediately before such change shall have become effective until such notice shall have been withdrawn or such provision amended in accordance herewith.

Example 3 Frozen GAAP provision.

A loan and security agreement of American Railcar Industries, INC. dated as of January 24, 2006.

Accounting Terms and Determinations. Unless otherwise defined or specified herein, all accounting terms used in this Agreement shall be construed in accordance with GAAP, applied on a basis consistent in all material respects with the Financial Statements delivered to the Agent on or before the Closing

49 "Without renegotiation" means the credit agreement does not explicitly mention the terms related to renegotiation. 
Date. All accounting determinations for purposes of determining compliance with Article VIII shall be made in accordance with GAAP as in effect on the Closing Date and applied on a basis consistent in all material respects with the audited Financial Statements delivered to the Agent on or before the Closing Date. The Financial Statements required to be delivered hereunder from and after the Closing Date, and all financial records, shall be maintained in accordance with GAAP. If GAAP shall change from the basis used in preparing the audited Financial Statements delivered to the Agent on or before the Closing Date, the Compliance Certificates required to be delivered pursuant to Section 7.1 shall include calculations setting forth the adjustments necessary to demonstrate how the Borrower is in compliance with the Financial Covenants based upon GAAP as in effect on the Closing Date.

Example 4 Floating GAAP provision.

A loan agreement of $B B \& T$ dated as of May 13, 2015

"GAAP" shall mean generally accepted accounting principles as established by the Financial Accounting Standards Board or the American Institute of Certified Public Accountants, as amended and supplemented from time to time. 


\section{Appendix II \\ Variable Descriptions}

\begin{tabular}{ll}
\hline Variable & Description \\
\hline Collateral & An indicator variable that equals one if the contract is secured by \\
& collateral, and zero otherwise, from DealScan. \\
Conservatism & The C-Score $\left(\lambda_{1}+\lambda_{2}\right.$ Size $+\lambda_{3} \mathrm{M} / \mathrm{B}+\lambda_{4}$ Leverage $)$ of Khan and Watts (2009), \\
& where the coefficients are derived from the annual cross-sectional regression \\
& model as follows: $\mathrm{E}_{\mathrm{i}}=\beta_{1}+\beta_{2} \mathrm{D}_{\mathrm{i}}+\mathrm{R}_{\mathrm{i}}\left(\mu_{1}+\mu_{2} \mathrm{Size}_{\mathrm{i}}+\mu_{3} \mathrm{M} / \mathrm{B}_{\mathrm{i}}+\mu_{4}\right.$ Leverage $\left._{\mathrm{i}}\right)+$ \\
& $\mathrm{D}_{\mathrm{i}} \mathrm{R}_{\mathrm{i}}\left(\lambda_{1}+\lambda_{2} \mathrm{Size}_{\mathrm{i}}+\lambda_{3} \mathrm{M} / \mathrm{B}_{\mathrm{i}}+\lambda_{4}\right.$ Leverage $\left._{\mathrm{i}}\right)+\left(\delta_{1}\right.$ Size $_{\mathrm{i}}+\delta_{2} \mathrm{M} / \mathrm{B}_{\mathrm{i}}+\delta_{3}$ Leverage $_{\mathrm{i}}$ \\
& $+\delta_{4} \mathrm{D}_{\mathrm{i}} \mathrm{Size}_{\mathrm{i}}+\delta_{5} \mathrm{D}_{\mathrm{i}} \mathrm{M} / \mathrm{B}_{\mathrm{i}}+\delta_{6} \mathrm{D}_{\mathrm{i}}$ Leverage $\left._{\mathrm{i}}\right)+\varepsilon_{\mathrm{i}}$.
\end{tabular}

Covenant Tightness

The aggregate probability of covenant violations of loan packages initiated between 1996 and 2015, from Demerjian and Owens (2016). The probability is calculated using the logic of the Murfin (2012) measure that combines the initial slack of each covenant, the volatility of financial matrixes underlying each covenant and the correlation among those financial matrixes. The definitions of financial matrixes are the standard covenant definitions that minimize measurement error.

Credit Rating Borrowers' bond rating (defined as one for the highest rated loan to 16 for the lowest rated loan), and zero otherwise.

Cumret

Cumulative negative stock returns equal the buy-and-hold return of all negative price shocks where monthly return is less than $-28 \%$. For example, if a firm experiences two negative price shocks during the facility initiation date and the sample ending, then the cumulative negative stock returns equal the sum of the sizes of the two shocks.

Dividend An indicator variable that equals one for dividend paying borrowers, and zero otherwise.

False Positives_1 An indicator variable that equals one if a borrower that has positive stock returns adjusted by value-weighted return in two consecutive quarters reports a debt covenant violation in the SEC filings, and zero otherwise.

False Positives_2 An indicator variable that equals one if a borrower that has credit rating upgrades in the year prior to debt covenant violations, and zero otherwise.

False Positives_3 An indicator variable that equals one if a borrower that has positive bond returns in two consecutive quarters reports a debt covenant violation in the SEC filings, and zero otherwise.

Financial Complexity The number of words in 10-K divided by 1000 .

Firm Size

The log of market value of equity.

Floating GAAP

An indicator variable that equals one if a GAAP provision does not include the terms (or the variation of the terms) of Frozen GAAP and Frozen-onRequest GAAP, and zero otherwise. 


\section{Appendix II}

Variable Descriptions (Continued)

\begin{tabular}{|c|c|}
\hline Variable & Description \\
\hline Frozen GAAP & $\begin{array}{l}\text { An indicator variable that equals one if a GAAP provision includes the terms } \\
\text { (or the variation of the terms): "GAAP in effect on Jan", "in effect as of the } \\
\text { Closing Date", "in effect on or before the Effective Date", "GAAP as in } \\
\text { effect at the most recent", "GAAP as applied to statements dated", "prior to } \\
\text { the delivery of the first financial statement", "no such change shall", } \\
\text { "GAAP had not occurred", "without reflecting such change", "GAAP shall } \\
\text { not include modifications", "with the past accounting practices", etc., and } \\
\text { zero otherwise. }\end{array}$ \\
\hline $\begin{array}{l}\text { Frozen GAAP with } \\
\text { Renegotiation }\end{array}$ & $\begin{array}{l}\text { An indicator variable that equals one if a GAAP provision includes the terms } \\
\text { of Frozen GAAP and the term (or the variation of the term): "renegotiation", } \\
\text { "agree to amend", etc., and zero otherwise. }\end{array}$ \\
\hline $\begin{array}{l}\text { Frozen-on-Request } \\
\text { GAAP }\end{array}$ & $\begin{array}{l}\text { An indicator variable that equals one if a GAAP provision includes the terms } \\
\text { (or the variation of the terms): "at the request of either the Borrower or the } \\
\text { Required Lenders", "following notice either from", "if the Borrower or the } \\
\text { Required Lenders request", "either the Borrowers or the Required Lenders } \\
\text { shall request", "if Borrower notifies...or if the Required Lenders notify", } \\
\text { "Borrower may by notice to Required Lenders, or Required Lenders may by } \\
\text { notice to Borrower", etc., and zero otherwise. }\end{array}$ \\
\hline $\begin{array}{l}\text { Institutional Facility } \\
\text { Indicator }\end{array}$ & $\begin{array}{l}\text { An indicator variable that equals one if the facility is a term loan tranche B } \\
\text { or higher, and zero otherwise, from DealScan. }\end{array}$ \\
\hline Lender Reputation & $\begin{array}{l}\text { An indicator variable equal to one if the lead arranger is one of the top ten } \\
\text { lenders reported in Ross (2010), and zero otherwise. }\end{array}$ \\
\hline Leverage & The ratio of long-term debt plus debt in current liabilities to total assets. \\
\hline Loan Size & The natural logarithm of the loan amount, from DealScan. \\
\hline Month_to_Maturity & $\begin{array}{l}\text { The natural logarithm of the number of months between the first negative } \\
\text { stock price shock (or the data date in Equation 3) and loan maturity. }\end{array}$ \\
\hline No Rating & $\begin{array}{l}\text { An indicator variable equal to one if the borrower is not rated, and zero } \\
\text { otherwise. }\end{array}$ \\
\hline Num_Covenant & The number of debt covenants, from DealScan. \\
\hline Num_GAAP_Change & The lagged number of GAAP changes announced in the FASB's website. \\
\hline Num_Lender & The natural logarithm of the number of loan lenders, from DealScan. \\
\hline Num_Lender_Sq & The square of the natural logarithm of the number of loan lenders. \\
\hline Num_Month & $\begin{array}{l}\text { The natural logarithm of the number of months between the first negative } \\
\text { stock price shock defined as less than }-28 \% \text { monthly return and the first } \\
\text { covenant violation following the price shock if covenant violations occur or } \\
\text { the sample ending or loan maturity if no covenant violation occur. }\end{array}$ \\
\hline$R \& D$ & The research and development expense scaled by total revenue. \\
\hline Rating & $\begin{array}{l}\text { Estimated credit quality based on the predicted value of Barth, Hodder, and } \\
\text { Stubben (2008)'s model. }\end{array}$ \\
\hline
\end{tabular}




\section{Appendix II}

Variable Descriptions (Continued)

\begin{tabular}{ll}
\hline Variable & Description \\
\hline Revolver & An indicator variable that equals one if the facility's type is revolver, and \\
& zero otherwise, from DealScan. \\
ROA & The ratio of net income to total assets. \\
The amount the borrower pays in basis points over LIBOR for each dollar \\
drawn down, from DealScan.
\end{tabular}

\section{Appendix III}

Debt Covenant Violation Search Terms in Nini et al. (2012)

"in violation of covenant", "in violation of a covenant", "in default of covenant", "in default of a covenant", "in technical violation of covenant", "in technical violation of a covenant", "in violation of financial covenant", "in violation of a financial covenant", "in default of financial covenant", "in default of a financial covenant", "in technical violation of financial covenant", "in technical violation of a financial covenant", "in technical default of financial covenant", "in technical default of a financial covenant", "not in compliance", "out of compliance", "received waiver", "received a waiver", “obtained waiver", "obtained a waiver". 


\section{FIGURE 1}

\section{The Trends of the Types of GAAP Provisions}

\section{Panel A. The Trends of the Three Types of GAAP Provisions}

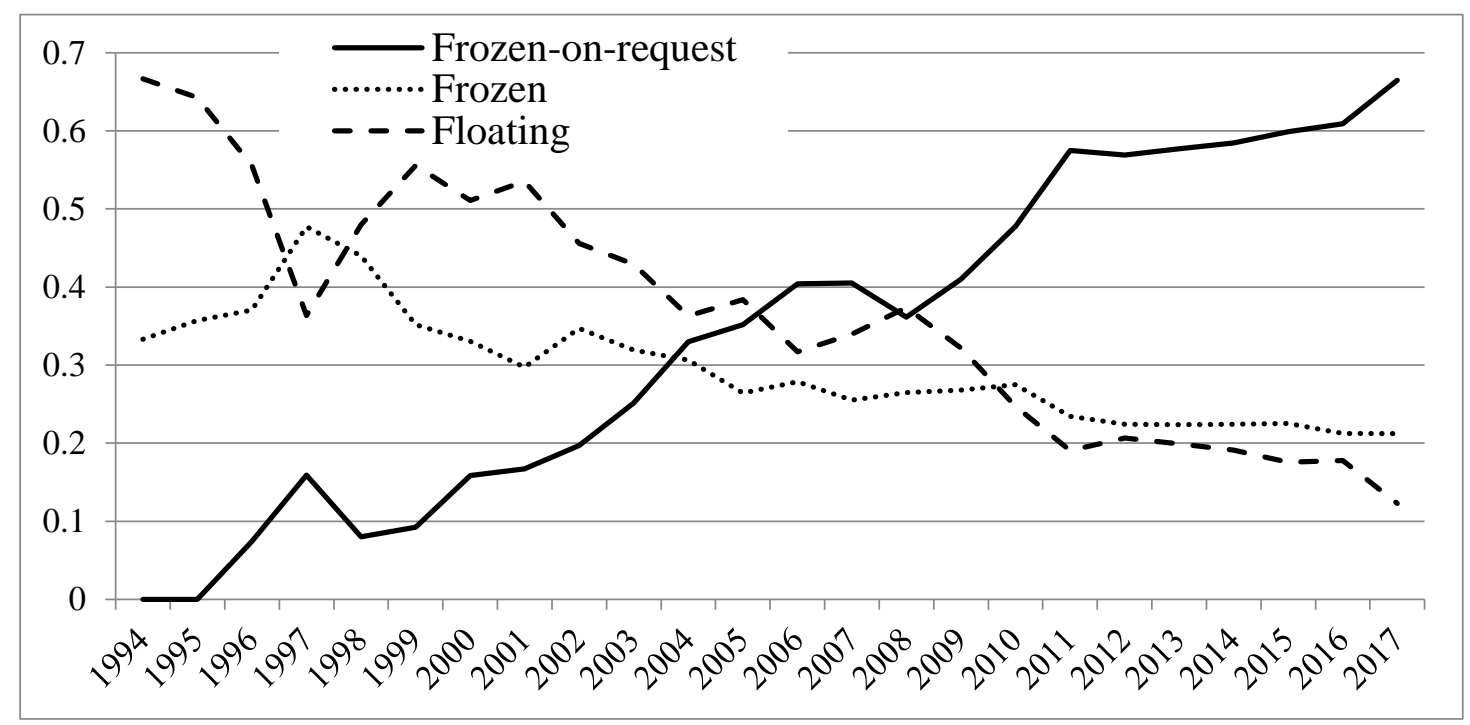

\section{Panel B. The Trends of the Two Types of Frozen-on-Request GAAP}

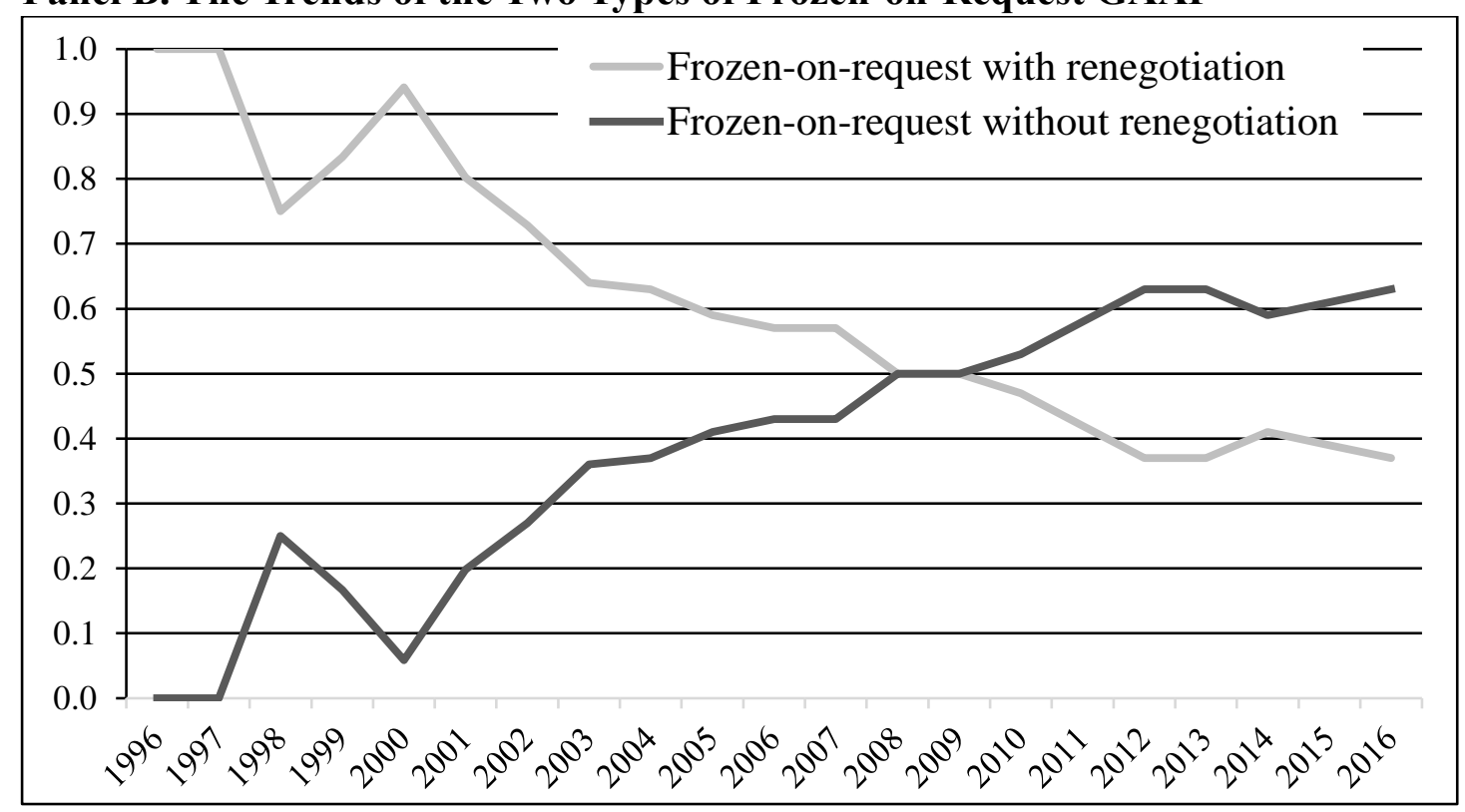

This figure shows the trend in contracting practice in terms of GAAP provisions. I collect 18,923 private debt contracts issued between 1994 and 2017 from the Edgar. Based on the GAAP provisions, I classify those contracts into three categories, frozen-on-request GAAP, frozen GAAP, and floating GAAP. Panel A presents the trends in the three types of GAAP provisions. In this panel, floating GAAP experienced a sharp drop but frozen GAAP had an abrupt increase in 1997. The opposing directions might be explained by the anticipation of the adoption of SFAS 133 (Accounting for Derivative Instruments and Hedging Activities) in June 1998. Within frozen-on-request GAAP, there are two types. In one type renegotiations are necessary when either party requests a freeze (i.e., frozen-on-request with renegotiation) and in the other type renegotiations are not necessary (i.e., frozen-on-request without renegotiation). Panel B shows the trends in the two types. 
FIGURE 2

Frozen-on-Request GAAP's Advantages before Renegotiations

\begin{tabular}{|c|c|c|c|c|c|c|c|c|c|}
\hline & & & Frozen & Floating & \multicolumn{5}{|c|}{ Frozen-on-Request } \\
\hline & & & Result & Result & Borrower & Lender & Result & $\begin{array}{c}\text { Effect on False Positives and } \\
\text { False Negatives }\end{array}$ & $\begin{array}{c}\text { Conflict } \\
\text { Preferences }\end{array}$ \\
\hline \multirow{2}{*}{$\begin{array}{c}\text { GAAP } \\
\text { Changes } \\
\text { Beneficial to } \\
\text { Efficiency }\end{array}$} & Tighten & 1 & Exclude & Incorporate & Reject & Accept & Exclude & Not reduce false negatives & Yes \\
\hline & Loosen & 2 & Exclude & Incorporate & Accept & Accept & Incorporate & Reduce false positives & No \\
\hline \multirow{2}{*}{$\begin{array}{c}\text { GAAP } \\
\text { Changes } \\
\text { Detrimental } \\
\text { to Efficiency }\end{array}$} & Tighten & 3 & Exclude & Incorporate & Reject & Reject & Exclude & Reduce false positives & No \\
\hline & Loosen & 4 & Exclude & Incorporate & Accept & Reject & Exclude & Reduce false negatives & Yes \\
\hline
\end{tabular}

This figure shows the exclusion and incorporation of GAAP changes under the three types of GAAP provisions before contract renegotiations. Although frozen-on-request GAAP would exclude GAAP changes beneficial to debt contracting efficiency but tightening covenants, it remains more useful in reducing false positives and false negatives than frozen and floating GAAP. 
FIGURE 3

Frozen-on-Request GAAP's Advantages in Reducing Renegotiation Costs and Facilitating Renegotiations

\begin{tabular}{|c|c|c|c|}
\hline & \multicolumn{2}{|c|}{ No Conflict } & \multirow{2}{*}{ Conflict } \\
\hline & Both prefer new GAAP & Both prefer old GAAP & \\
\hline Frozen-on-Request & No & $\begin{array}{c}\text { No; } \\
\text { Renegotiate }\end{array}$ & $\begin{array}{c}\text { Less likely to renegotiate; } \\
\text { Renegotiate }\end{array}$ \\
\hline Frozen & Renegotiate & No & Less likely to renegotiate \\
\hline Floating & No & Renegotiate & Less likely to renegotiate \\
\hline
\end{tabular}

This figure shows frozen-on-request GAAP's advantages in reducing renegotiation costs and facilitating renegotiations. When both borrowers and lenders prefer new GAAP, no renegotiation is needed under frozen-on-request GAAP and floating GAAP, and renegotiations are required under frozen GAAP; and when both prefer old GAAP, under frozen-on-request GAAP the necessity of renegotiation depends on the types of frozen-on-request GAAP, and renegotiations are necessary under floating GAAP but are not required under frozen GAAP. The renegotiation outcome under the two scenarios is to restore ex post efficiency. Therefore, I argue that frozen-on-request GAAP can restore efficiency at a lower cost when borrowers and lenders have the same preference towards GAAP changes. When borrowers and lenders have conflicting preferences, under frozen and floating GAAP the two parties are less likely to enter into renegotiations because either can reject renegotiations and hold up the other. Under one type of frozenon-request GAAP the two parties shall enter into renegotiations and therefore frozen-on-request GAAP can facilitate renegotiations. However, the renegotiation outcome in this scenario is not necessarily restore efficiency because borrowers can abuse the renegotiations to push lenders to agree to reject GAAP changes beneficial to contracting efficiency but tightening covenants. 
FIGURE 4

The Effect of Two Types of Frozen-on-Request GAAP

Panel A: The effect on false positives

\begin{tabular}{|c|c|c|c|c|c|c|}
\hline & \multicolumn{3}{|c|}{ Frozen-on-Request } & \multirow[b]{2}{*}{ Frozen } & \multirow[b]{2}{*}{ Floating } \\
\hline & & $\begin{array}{l}\text { Effect on False Positives } \\
\text { and False Negatives }\end{array}$ & $\begin{array}{l}\text { FOR without } \\
\text { Renegotiation }\end{array}$ & $\begin{array}{c}\text { FOR with } \\
\text { Renegotiation }\end{array}$ & & \\
\hline 2 & Both prefer new GAAP & Reduce false positives & Not renegotiate & Not renegotiate & Renegotiate & Not renegotiate \\
\hline 3 & Both prefer old GAAP & Reduce false positives & Not renegotiate & Renegotiate & Not renegotiate & Renegotiate \\
\hline
\end{tabular}

\section{Panel B: The effect on false negatives}

\begin{tabular}{|c|c|c|c|c|c|c|}
\hline \multicolumn{2}{|c|}{} & \multicolumn{2}{|c|}{ Frozen-on-Request } & \multirow{2}{*}{ Frozen } & \multirow{2}{*}{ Floating } \\
\cline { 3 - 6 } \multicolumn{2}{|c|}{} & $\begin{array}{c}\text { Effect on False Positives } \\
\text { and False Negatives }\end{array}$ & $\begin{array}{c}\text { FOR without } \\
\text { Renegotiation }\end{array}$ & $\begin{array}{c}\text { FOR with } \\
\text { Renegotiation }\end{array}$ & $\begin{array}{c}\text { Less likely to } \\
\text { renegotiate }\end{array}$ & $\begin{array}{c}\text { Less likely to } \\
\text { renegotiate }\end{array}$ \\
\hline 1 & Conflicting Preferences & Not reduce false negatives & $\begin{array}{c}\text { Less likely to } \\
\text { renegotiate }\end{array}$ & Renegotiate & $\begin{array}{c}\text { Less likely to } \\
\text { renegotiate }\end{array}$ & $\begin{array}{c}\text { Less likely to } \\
\text { renegotiate }\end{array}$ \\
\hline 4 & Conflicting Preferences & Reduce false negatives & $\begin{array}{c}\text { Less likely to } \\
\text { renegotiate }\end{array}$ & Renegotiate &
\end{tabular}

This figure demonstrates the analyses of the two types of frozen-on-request GAAP by combing Figure 1 and Figure 2. In scenarios 2 and 3, frozen-on-request GAAP without renegotiation can save renegotiation costs and therefore is more useful in reducing false positives. In scenarios 1 and 4 , frozen-on-request GAAP with renegotiation can facilitate renegotiations and therefore is more useful in reducing false negatives. 
FIGURE 5

The Frequency of Downgrades across the Decile of Bond Returns

\begin{tabular}{|c|c|c|c|c|c|c|c|c|c|}
\hline $\begin{array}{c}\text { Decile of the sum of } \\
\text { bond returns in two } \\
\text { consecutive quarters }\end{array}$ & $\begin{array}{c}\text { Bottom } \\
0-0.1\end{array}$ & $0.1-0.2$ & $0.2-0.3$ & $0.3-0.4$ & $0.4-0.5$ & $0.5-0.6$ & $0.6-0.7$ & $0.7-0.8$ & $0.8-0.9$ \\
\hline $\begin{array}{c}\text { Frequency of } \\
\text { downgrades }\end{array}$ & $23.20 \%$ & $10.24 \%$ & $7.31 \%$ & $6.67 \%$ & $6.67 \%$ & $7.09 \%$ & $6.57 \%$ & $5.99 \%$ & $7.34 \%$ \\
\hline
\end{tabular}

This figure shows the frequency of downgrades from the bottom decile of the sum of bond returns in one preceding quarter and the concurrent quarter to the top decile. The frequency of downgrades is highest in the bottom decile and is the second highest in the bottom $20 \%$, supporting the notion that bond returns have the ability to capture changes in creditworthiness. 
TABLE 1

Sample Selection

\begin{tabular}{|c|c|}
\hline Sample Selection Criteria & Sample Size \\
\hline $\begin{array}{l}\text { All Exhibit } 10 \text { s of forms } 10-\mathrm{K}, 10-\mathrm{Q} \text {, or } \\
8 \text {-K filed to the SEC during Jan } 1994 \text { to } \\
\text { Dec } 2017\end{array}$ & 870,907 Exhibit 10 files \\
\hline $\begin{array}{l}\text { Restrict to Exhibit } 10 \text { s containing the } \\
\text { terms "credit agreement", "loan } \\
\text { agreement", or "loan and security } \\
\text { agreement"; the words "GAAP" or } \\
\text { "Generally Accepted Accounting } \\
\text { Principles"; and "financial covenants" or } \\
\text { "negative covenants" }\end{array}$ & 45,639 Exhibit 10 files \\
\hline $\begin{array}{l}\text { Drop short Exhibit } 10 \text { s containing less } \\
\text { than } 7,000 \text { words }\end{array}$ & 43,460 Exhibit 10 files \\
\hline $\begin{array}{l}\text { Require that the first } 3,072 \text { characters of } \\
\text { each Exhibit } 10 \text { contain the terms "credit } \\
\text { agreement", "loan agreement", or "loan } \\
\text { and security agreement" }\end{array}$ & 26,855 Exhibit 10 files \\
\hline $\begin{array}{l}\text { Drop Exhibit 10s that don't contain } \\
\text { enough information on the GAAP } \\
\text { provision design }\end{array}$ & 24,026 Exhibit 10 files \\
\hline Merge with Compustat via CIK identifier & 18,923 Exhibit 10 files \\
\hline Restrict to non-financial U.S. firms ${ }^{50}$ & 16,835 Exhibit 10 files \\
\hline $\begin{array}{l}\text { Merge with DealScan manually and } \\
\text { restrict to loans with more than five-year } \\
\text { maturity }^{51}\end{array}$ & 6,927 facilities for 2,144 unique firms \\
\hline $\begin{array}{l}\text { Require non-missing values of regression } \\
\text { variables in Equation (1) }\end{array}$ & 5,605 facilities for 1,716 unique firms \\
\hline
\end{tabular}

\footnotetext{
${ }^{50}$ The main reason is to avoid duplications. A borrower reports a debt contract in its SEC filings, and at the same time the lender (most of lenders are financial firms) may report it as a commitment letter.

${ }^{51}$ The sample size reduces significantly for the following reasons: 1 . The restriction on maturity; 2 . Sample duplications caused by borrowers' multiple reports; 3. A valid DealScan-Compustat link based on company identity shared by Chava and Roberts (2008).
} 
TABLE 2

Frequency of Private Debt Contracts by Filing Years

\begin{tabular}{ccc}
\hline & & Obs. (N) \\
\cline { 2 - 3 } Filing Year & Initial Sample & Regression Sample \\
\hline 1994 & $(1)$ & 0 \\
1995 & 6 & 0 \\
1996 & 14 & 12 \\
1997 & 28 & 16 \\
1998 & 44 & 7 \\
1999 & 50 & 6 \\
2000 & 55 & 22 \\
2001 & 228 & 70 \\
2002 & 661 & 97 \\
2003 & 915 & 126 \\
2004 & 1015 & 367 \\
2005 & 1287 & 447 \\
2006 & 1346 & 370 \\
2007 & 1190 & 435 \\
2008 & 1112 & 163 \\
2009 & 841 & 71 \\
2010 & 845 & 228 \\
2011 & 1272 & 630 \\
2012 & 1494 & 467 \\
2013 & 1216 & 545 \\
2014 & 1217 & 534 \\
2015 & 1349 & 527 \\
2016 & 1286 & 441 \\
2017 & 1269 & 25 \\
Total & 179 & 5,605 \\
& 18,923 &
\end{tabular}

This table presents the sample distribution of private debt contracts by filing years. I extract debt contracts issued between 1994 and 2017 from the Edgar and require that (1) agreements include the terms "GAAP" or "Generally Accepted Accounting Principles", and "financial covenants" or "negative covenants"; (2) agreements contain more than 7,000 words; (3) agreements contain enough information on GAAP provision designs to judge the GAAP provision types; (4) agreements can be linked to Compustat via CIK identifier. Columns 1 and 2 show the number of debt contracts in my initial sample (i.e., 18,923 debt contracts) and my regression sample (i.e., 5,605 facilities). 
TABLE 3

Descriptive Statistics

Panel A: Equation 1 - Determinant Model

\begin{tabular}{lcccccccc}
\hline Variable & $\mathrm{N}$ & Mean & Q1 & Median & Q3 & Min & Max & s.d. \\
\hline Frozen-on-Request & 5,605 & 0.642 & 0 & 1 & 1 & 0 & 1 & 0.480 \\
GAAP & 5,605 & 0.258 & 0 & 0 & 1 & 0 & 1 & 0.437 \\
Frozen GAAP & 5,605 & 0.101 & 0 & 0 & 0 & 0 & 1 & 0.301 \\
Floating GAAP & 5,605 & 0.020 & 0 & 0 & 0.016 & 0 & 0.230 & 0.043 \\
R\&D & 5,605 & 1.766 & 1.200 & 1.498 & 2.005 & 0.786 & 6.066 & 0.900 \\
Tobin's $Q$ & 5,605 & 0.559 & 0.335 & 0.471 & 0.699 & 0.162 & 1.841 & 0.321 \\
Volatility & 5,605 & 0.392 & 0.003 & 0.372 & 0.731 & -1.263 & 2.390 & 0.641 \\
Conservatism & 5,605 & 7.460 & 6.468 & 7.449 & 8.447 & 4.066 & 11.004 & 1.480 \\
Firm Size & 5,605 & 0.569 & 0 & 1 & 1 & 0 & 1 & 0.495 \\
Collateral & 5,605 & 2.004 & 1.609 & 2.079 & 2.565 & 0 & 4.727 & 0.853 \\
Num_Lender & 5,605 & 4.732 & 2.590 & 4.324 & 6.579 & 0 & 13.039 & 3.114 \\
Num_Lender_Sq & 5,605 & 1.641 & 0 & 2 & 2 & 0 & 7 & 1.296 \\
Num_Covenant & 5,605 & 10.855 & 4 & 7 & 17 & 1 & 29 & 8.373 \\
Num_GAAP_Change & 5,605 & 3.853 & 0 & 0 & 10 & 0 & 15 & 5.124 \\
Credit Rating & 5,605 & 0.622 & 0 & 1 & 1 & 0 & 1 & 0.485 \\
No Rating & 5,605 & 0.221 & 0.081 & 0.158 & 0.289 & 0.009 & 1.140 & 0.208 \\
Loan/Asset & 5,605 & 0.646 & 0 & 1 & 1 & 0 & 1 & 0.478 \\
Revolver & 5,605 & 47.042 & 32.281 & 41.642 & 54.912 & 13.544 & 150.9 & 23.567 \\
FinancialComplexity & 5,605 & 0.851 & 1 & 1 & 1 & 0 & 1 & 0.356 \\
Lender Reputation & & & & & & & &
\end{tabular}

Panel B: Equation 2 - False Positives Using the Positive Stock Return Sample

\begin{tabular}{lcccccccc}
\hline Variable & $\mathrm{N}$ & Mean & $\mathrm{Q} 1$ & Median & $\mathrm{Q} 3$ & Min & Max & s.d. \\
\hline Frozen-on- & 10,503 & 0.653 & 0 & 1 & 1 & 0 & 1 & 0.476 \\
Request GAAP & 10,503 & 0.239 & 0 & 0 & 0 & 0 & 1 & 0.426 \\
Frozen GAAP & 10,503 & 0.109 & 0 & 0 & 0 & 0 & 1 & 0.311 \\
Floating GAAP & 10,503 & 0.016 & 0 & 0 & 0 & 0 & 1 & 0.124 \\
Violation & 10,503 & 0.045 & 7.652 \\
Firm Size & 10,503 & 7.607 & 6.626 & 7.665 & 8.598 & 3.588 & 11.427 & 1.521 \\
Leverage & 10,503 & 0.328 & 0.186 & 0.296 & 0.428 & 0 & 0.933 & 0.204 \\
ROA & 10,503 & 0.046 & 0.021 & 0.049 & 0.080 & -0.244 & 0.217 & 0.065 \\
Dividend & 10,503 & 0.556 & 0 & 1 & 1 & 0 & 1 & 0.497 \\
Std_Cash Flows & 10,503 & 141.951 & 21.613 & 52.622 & 132.886 & 2.264 & 1830.507 & 269.827 \\
Covenant & 10,503 & 0.274 & 0.004 & 0.041 & 0.602 & 0 & 1 & 0.384 \\
Tightness & 10,503 & -4.194 & -5.075 & -4.218 & -3.394 & -7.077 & -0.555 & 1.277 \\
Rating & 10,503 & 0.566 & 0 & 1 & 1 & 0 & 1 & 0.496 \\
Collateral & & & & & & & & \\
\hline
\end{tabular}

Panel C: Equation 2 - False Positives Using the Credit Rating Upgrade Sample

\begin{tabular}{lcccccccc}
\hline Variable & $\mathrm{N}$ & Mean & $\mathrm{Q} 1$ & Median & $\mathrm{Q} 3$ & Min & Max & s.d. \\
\hline Frozen-on- & 1,700 & 0.638 & 0 & 1 & 1 & 0 & 1 & 0.481 \\
Request GAAP & 1,700 & 0.251 & 0 & 0 & 1 & 0 & 1 & 0.434 \\
Frozen GAAP & 1,700 & 0.111 & 0 & 0 & 0 & 0 & 1 & 0.314 \\
Floating GAAP & 1,700 & 0.047 & 0 & 0 & 0 & 0 & 1 & 0.212 \\
Violation & 1,700 & & 0 & & \\
Firm Size & 1,700 & 8.033 & 7.173 & 8.082 & 9.001 & 3.626 & 11.914 & 1.504 \\
Leverage & 1,700 & 0.389 & 0.246 & 0.354 & 0.488 & 0.053 & 1.000 & 0.206 \\
ROA & 1,700 & 0.031 & 0.011 & 0.034 & 0.064 & -0.414 & 0.231 & 0.080 \\
\hline
\end{tabular}


Panel C: Equation 2 - False Positives Using the Credit Rating Upgrade Sample (Continued)

\begin{tabular}{lcccccccc}
\hline Variable & $\mathrm{N}$ & Mean & $\mathrm{Q} 1$ & Median & $\mathrm{Q} 3$ & Min & Max & s.d. \\
\hline Dividend & 1,700 & 0.629 & 0 & 1 & 1 & 0 & 1 & 0.483 \\
Std_Cash Flows & 1,700 & 261.091 & 51.123 & 107.078 & 232.436 & 10.132 & 3298.26 & 475.078 \\
Covenant & 1,700 & 0.287 & 0.002 & 0.045 & 0.642 & 0 & 1 & 0.391 \\
Tightness & & & & & & & \\
Rating & 1,700 & -4.658 & -5.682 & -4.852 & -3.728 & -7.682 & -0.841 & 1.422 \\
Collateral & 1,700 & 0.579 & 0 & 1 & 1 & 0 & 1 & 0.494 \\
\hline
\end{tabular}

Panel D: Equation 3 - False Negatives

\begin{tabular}{|c|c|c|c|c|c|c|c|c|}
\hline Variable & $\mathrm{N}$ & Mean & Q1 & Median & Q3 & Min & Max & s.d. \\
\hline $\begin{array}{l}\text { Frozen-on-Request } \\
\text { GAAP }\end{array}$ & 1,322 & 0.567 & 0 & 1 & 1 & 0 & 1 & 0.496 \\
\hline Frozen GAAP & 1,322 & 0.293 & 0 & 0 & 1 & 0 & 1 & 0.456 \\
\hline Floating GAAP & 1,322 & 0.140 & 0 & 0 & 0 & 0 & 1 & 0.347 \\
\hline Log(Num_Month) & 1,310 & 2.856 & 2.316 & 3.200 & 3.778 & -3.401 & 4.724 & 1.187 \\
\hline Num_Month & 1,322 & 27.543 & 9.7 & 24.4 & 43.733 & 0 & 112.667 & 20.896 \\
\hline Cumret & 1,322 & -0.603 & -0.722 & -0.392 & -0.326 & -2.658 & -0.280 & 0.396 \\
\hline Firm Size & 1,322 & 6.043 & 4.784 & 6.238 & 7.500 & 0.815 & 10.352 & 2.005 \\
\hline Leverage & 1,322 & 0.432 & 0.229 & 0.380 & 0.582 & 0 & 1.463 & 0.285 \\
\hline$R O A$ & 1,322 & -0.053 & -0.077 & 0.001 & 0.037 & -0.921 & 0.235 & 0.180 \\
\hline Rating & 1,322 & -3.060 & -4.220 & -3.372 & -2.170 & -7.186 & 13.983 & 2.019 \\
\hline Loan Size & 1,322 & 18.939 & 18.133 & 19.114 & 19.868 & 14.935 & 21.822 & 1.377 \\
\hline Month-to-Maturity & 1,322 & 16.237 & 0.533 & 1.033 & 30.533 & 0.033 & 142.033 & 21.870 \\
\hline Num_Covenant & 1,322 & 2 & 1 & 2 & 3 & 0 & 6 & 1.456 \\
\hline
\end{tabular}

Panel E: Equation 4 - Loan Spreads

\begin{tabular}{lcccccccc}
\hline Variable & $\mathrm{N}$ & Mean & Q1 & Median & Q3 & Min & Max & s.d. \\
\hline Frozen-on-Request & 5,373 & 0.646 & 0 & 1 & 1 & 0 & 1 & 0.478 \\
GAAP & 5,373 & 0.259 & 0 & 0 & 1 & 0 & 1 & 0.438 \\
Frozen GAAP & 5,373 & 0.095 & 0 & 0 & 0 & 0 & 1 & 0.294 \\
Floating GAAP & 5,373 & 199.218 & 125 & 175 & 250 & 25 & 675 & 117.460 \\
Spread & 5,373 & 63.774 & 60 & 60 & 60 & 60 & 181 & 63.774 \\
Maturity & 5,373 & 0.653 & 0 & 1 & 1 & 0 & 1 & 0.476 \\
Revolver & 5,373 & 0.225 & 0.084 & 0.161 & 0.293 & 0.009 & 1.196 & 0.212 \\
Loan/Asset & 5,373 & 0.302 & 0.145 & 0.278 & 0.422 & 0 & 1.849 & 0.216 \\
Leverage & 5,373 & 0.042 & 0.018 & 0.044 & 0.076 & -0.924 & 0.679 & 0.080 \\
ROA & 5,373 & -4.204 & -5.131 & -4.251 & -3.359 & -7.077 & -0.555 & 1.319 \\
Rating & 5,373 & 1.675 & 0 & 2 & 2 & 0 & 7 & 1.290 \\
Num_Covenant & & & & & & & &
\end{tabular}

This table reports the number of observations $(\mathrm{N})$, mean, $25^{\text {th }}$ percentile, median, $75^{\text {th }}$ percentile, minimum, maximum, and standard deviation (s.d.) for variables used in my main regressions. See the Appendix II for variable definitions. All continuous variables are winsorized at the $1 \%$ and $99 \%$ percentiles. 
TABLE 4

Determinants of GAAP provision Types

\begin{tabular}{|c|c|c|c|c|}
\hline & $\begin{array}{c}\text { Frozen-on- } \\
\text { Request or } \\
\text { Frozen }=1 \& \\
\text { Floating }=0 \\
\text { (1) }\end{array}$ & $\begin{array}{l}\text { Frozen-on- } \\
\text { Request }=1 \& \\
\text { Floating }=0 \\
\text { (2) }\end{array}$ & $\begin{array}{l}\text { Frozen-on- } \\
\text { Request }=1 \& \\
\text { Frozen }=0 \\
\text { (3) }\end{array}$ & $\begin{array}{c}\text { Frozen-on- } \\
\text { Request }=1 \& \\
\text { Non-Frozen- } \\
\text { on-Request }=0 \\
\text { (4) }\end{array}$ \\
\hline Firm Size & $\begin{array}{c}-0.064 * * \\
(0.049)\end{array}$ & $\begin{array}{c}-0.069^{*} \\
(0.056)\end{array}$ & $\begin{array}{l}-0.034 \\
(0.188)\end{array}$ & $\begin{array}{c}-0.059 * * \\
(0.014)\end{array}$ \\
\hline Credit Rating & $\begin{array}{c}0.141 * * * \\
(0.000)\end{array}$ & $\begin{array}{c}0.174 * * * \\
(0.000)\end{array}$ & $\begin{array}{l}-0.004 \\
(0.802)\end{array}$ & $\begin{array}{c}0.057 * * * \\
(0.000)\end{array}$ \\
\hline No Rating & $\begin{array}{c}1.592 * * * \\
(0.000)\end{array}$ & $\begin{array}{c}1.973 * * * \\
(0.000)\end{array}$ & $\begin{array}{c}0.111 \\
(0.532)\end{array}$ & $\begin{array}{c}0.779 * * * \\
(0.000)\end{array}$ \\
\hline Lender Reputation & $\begin{array}{c}0.424 * * * \\
(0.000)\end{array}$ & $\begin{array}{c}0.586^{* * * *} \\
(0.000)\end{array}$ & $\begin{array}{c}0.444 * * * \\
(0.000)\end{array}$ & $\begin{array}{c}0.509 * * * \\
(0.000)\end{array}$ \\
\hline Num_Lender & $\begin{array}{c}0.785 * * * \\
(0.000)\end{array}$ & $\begin{array}{c}0.850 * * * \\
(0.000)\end{array}$ & $\begin{array}{c}0.178 * * \\
(0.027)\end{array}$ & $\begin{array}{c}0.409 * * * \\
(0.000)\end{array}$ \\
\hline Num_Lender_Sq & $\begin{array}{c}-0.187 * * * \\
(0.000)\end{array}$ & $\begin{array}{c}-0.197 * * * \\
(0.000)\end{array}$ & $\begin{array}{l}-0.027 \\
(0.217)\end{array}$ & $\begin{array}{c}-0.084 * * * \\
(0.000)\end{array}$ \\
\hline Financial Complexity & $\begin{array}{l}-0.002 \\
(0.136)\end{array}$ & $\begin{array}{c}-0.003^{* *} \\
(0.011)\end{array}$ & $\begin{array}{l}-0.001 \\
(0.154)\end{array}$ & $\begin{array}{c}-0.002^{* *} \\
(0.047)\end{array}$ \\
\hline Conservatism & $\begin{array}{l}-0.054 \\
(0.366)\end{array}$ & $\begin{array}{l}-0.084 \\
(0.212)\end{array}$ & $\begin{array}{c}-0.076^{*} \\
(0.072)\end{array}$ & $\begin{array}{c}-0.092^{* *} \\
(0.018)\end{array}$ \\
\hline Collateral & $\begin{array}{c}0.056 \\
(0.362)\end{array}$ & $\begin{array}{l}-0.044 \\
(0.525)\end{array}$ & $\begin{array}{c}-0.116^{* *} \\
(0.014)\end{array}$ & $\begin{array}{c}-0.101^{* *} \\
(0.022)\end{array}$ \\
\hline Num_Covenant & $\begin{array}{c}0.024 \\
(0.300)\end{array}$ & $\begin{array}{c}0.037 \\
(0.161)\end{array}$ & $\begin{array}{c}0.017 \\
(0.358)\end{array}$ & $\begin{array}{c}0.025 \\
(0.137)\end{array}$ \\
\hline Revolver & $\begin{array}{l}-0.027 \\
(0.636)\end{array}$ & $\begin{array}{l}-0.014 \\
(0.819)\end{array}$ & $\begin{array}{c}0.008 \\
(0.848)\end{array}$ & $\begin{array}{l}-0.005 \\
(0.898)\end{array}$ \\
\hline$R \& D$ & $\begin{array}{c}-1.178^{*} \\
(0.059)\end{array}$ & $\begin{array}{l}-1.132 \\
(0.100)\end{array}$ & $\begin{array}{l}0.969^{*} \\
(0.062)\end{array}$ & $\begin{array}{c}0.374 \\
(0.419)\end{array}$ \\
\hline Tobin's $Q$ & $\begin{array}{c}0.131 * * * \\
(0.000)\end{array}$ & $\begin{array}{c}0.183 * * * \\
(0.000)\end{array}$ & $\begin{array}{c}0.121 * * * \\
(0.000)\end{array}$ & $\begin{array}{c}0.133 * * * \\
(0.000)\end{array}$ \\
\hline Volatility & $\begin{array}{l}-0.022 \\
(0.810)\end{array}$ & $\begin{array}{l}-0.059 \\
(0.586)\end{array}$ & $\begin{array}{c}0.014 \\
(0.843)\end{array}$ & $\begin{array}{l}-0.010 \\
(0.875)\end{array}$ \\
\hline Loan/Assets & $\begin{array}{l}-0.188 \\
(0.211)\end{array}$ & $\begin{array}{l}-0.149 \\
(0.381)\end{array}$ & $\begin{array}{c}0.094 \\
(0.412)\end{array}$ & $\begin{array}{c}0.020 \\
(0.851)\end{array}$ \\
\hline Num_GAAP_Change & $\begin{array}{c}0.128 \\
(0.368)\end{array}$ & $\begin{array}{c}0.170 \\
(0.235)\end{array}$ & $\begin{array}{c}0.137 * * * \\
(0.005)\end{array}$ & $\begin{array}{c}0.408^{* * * *} \\
(0.005)\end{array}$ \\
\hline Intercept & $\begin{array}{l}-2.698 \\
(0.275)\end{array}$ & $\begin{array}{l}-4.016 \\
(0.107)\end{array}$ & $\begin{array}{c}-2.042^{* *} \\
(0.018)\end{array}$ & $\begin{array}{c}-7.467 * * * \\
(0.003)\end{array}$ \\
\hline Year FE & Yes & Yes & Yes & Yes \\
\hline Pseudo R-sq & 0.166 & 0.229 & 0.068 & 0.102 \\
\hline N. of Obs & 5,605 & 4,161 & 5,013 & 5,605 \\
\hline
\end{tabular}

This table reports the determinants of GAAP provision types. The dependent variable in Column 1 is an indicator variable that equals one if the GAAP provision type is frozen-on-request or frozen GAAP; in Column 2 is an indicator variable that equals one for frozen-on-request GAAP, and zero for floating GAAP; in Column 3 is an indicator variable that equals one for frozen-on-request GAAP, and zero for frozen GAAP; and in Column 4 is an indicator variable that equals one for frozen-on-request GAAP, and zero for frozen and floating GAAP. $P$-value based on standard errors adjusted for heteroskedasticity is displayed in parentheses. See the Appendix II for variable definitions. All continuous variables are winsorized at the $1 \%$ and $99 \%$ percentiles. ${ }^{* * *},{ }^{* *}$, and ${ }^{*}$ indicate significance at the $1 \%, 5 \%$, and $10 \%$ levels, respectively. 
TABLE 5

The Effect of Frozen-on-Request GAAP on False Positives - Positive Stock Returns

\begin{tabular}{|c|c|c|c|c|c|c|c|c|c|}
\hline & \multicolumn{9}{|c|}{ False Positives 1} \\
\hline & \multicolumn{3}{|c|}{ Frozen-on-Request vs. Floating } & \multicolumn{3}{|c|}{ Frozen-on-Request vs. Frozen } & \multicolumn{3}{|c|}{$\begin{array}{c}\text { Frozen-on-Request vs. Non-Frozen-on- } \\
\text { Request }\end{array}$} \\
\hline & $\begin{array}{l}\text { Heckman } \\
\text { (1) }\end{array}$ & $\begin{array}{l}\text { Firthlogit } \\
\text { (2) }\end{array}$ & $\begin{array}{l}\text { Probit } \\
\text { (3) }\end{array}$ & $\begin{array}{l}\text { Heckman } \\
\text { (4) }\end{array}$ & $\begin{array}{l}\text { Firthlogit } \\
\quad(5)\end{array}$ & $\begin{array}{l}\text { Probit } \\
\text { (6) }\end{array}$ & $\begin{array}{l}\text { Heckman } \\
\quad(7)\end{array}$ & $\begin{array}{l}\text { Firthlogit } \\
\text { (8) }\end{array}$ & $\begin{array}{l}\text { Probit } \\
(9)\end{array}$ \\
\hline Frozen-on- & $-1.844 * * *$ & $-0.505 * *$ & $-0.192 * *$ & $-1.930 * * *$ & $-0.433 * *$ & $-0.186 * *$ & $-2.073 * * *$ & $-0.423 * *$ & $-0.174 * *$ \\
\hline Request $G A A P$ & $(0.000)$ & $(\mathbf{0 . 0 3 4})$ & $(\mathbf{0 . 0 3 8})$ & $(0.000)$ & $(\mathbf{0 . 0 2 0})$ & $(\mathbf{0 . 0 1 5 )}$ & $(0.000)$ & $(0.012)$ & $(\mathbf{0 . 0 1 1})$ \\
\hline \multirow[t]{2}{*}{ Firm Size } & $-0.124 * *$ & $-0.463 * * *$ & $-0.199 * * *$ & $-0.117 * *$ & $-0.422 * * *$ & $-0.184 * * *$ & $-0.104 * *$ & $-0.495 * * *$ & $-0.212 * * *$ \\
\hline & $(0.011)$ & $(0.000)$ & $(0.000)$ & $(0.013)$ & $(0.000)$ & $(0.000)$ & $(0.024)$ & $(0.000)$ & $(0.000)$ \\
\hline \multirow[t]{2}{*}{ Leverage } & -0.101 & -0.405 & -0.200 & -0.135 & 0.084 & 0.038 & -0.116 & -0.158 & -0.071 \\
\hline & $(0.669)$ & $(0.365)$ & $(0.212)$ & $(0.554)$ & $(0.841)$ & $(0.804)$ & $(0.604)$ & $(0.662)$ & $(0.623)$ \\
\hline \multirow[t]{2}{*}{$R O A$} & $-1.437 * *$ & $-4.294 * * *$ & $-1.968 * * *$ & $-1.317 * *$ & $-3.803 * * *$ & $-1.815 * * *$ & $-1.301 * *$ & $-4.351 * * *$ & $-2.062 * * *$ \\
\hline & $(0.038)$ & $(0.001)$ & $(0.000)$ & $(0.048)$ & $(0.001)$ & $(0.000)$ & $(0.046)$ & $(0.000)$ & $(0.000)$ \\
\hline \multirow[t]{2}{*}{ Dividend } & $-0.256^{* *}$ & -0.134 & -0.073 & $-0.245^{* *}$ & $-0.435^{* *}$ & $-0.187 * *$ & $-0.247 * *$ & -0.126 & -0.062 \\
\hline & $(0.027)$ & $(0.564)$ & $(0.418)$ & $(0.028)$ & $(0.044)$ & $(0.010)$ & $(0.024)$ & $(0.502)$ & $(0.368)$ \\
\hline \multirow[t]{2}{*}{ Collateral } & $0.561 * * *$ & $0.713 * *$ & $0.312 * *$ & $0.511 * * *$ & $0.642 * *$ & $0.233 * *$ & $0.512 * * *$ & 0.284 & 0.117 \\
\hline & $(0.001)$ & $(0.034)$ & $(0.015)$ & $(0.001)$ & $(0.033)$ & $(0.019)$ & $(0.001)$ & $(0.267)$ & $(0.203)$ \\
\hline \multirow[t]{2}{*}{ Rating } & -0.001 & $0.251 * *$ & $0.090 *$ & 0.001 & -0.038 & -0.035 & 0.002 & 0.133 & 0.038 \\
\hline & $(0.984)$ & $(0.031)$ & $(0.055)$ & $(0.985)$ & $(0.735)$ & $(0.431)$ & $(0.973)$ & $(0.163)$ & $(0.335)$ \\
\hline Covenant & $0.220 *$ & $0.443 *$ & $0.213^{*}$ & $0.202 *$ & $0.553 * *$ & $0.221 * *$ & $0.218 *$ & $0.539 * *$ & $0.228 * * *$ \\
\hline Tightness & $(0.062)$ & $(0.092)$ & $(0.060)$ & $(0.075)$ & $(0.015)$ & $(0.015)$ & $(0.050)$ & $(0.010)$ & $(0.009)$ \\
\hline \multirow[t]{2}{*}{ Std_Cash Flows } & 0.000 & $0.001 *$ & $0.000 * *$ & 0.000 & 0.001 & 0.000 & 0.000 & 0.001 & $0.000 *$ \\
\hline & $(0.446)$ & $(0.087)$ & $(0.010)$ & $(0.434)$ & $(0.184)$ & $(0.139)$ & $(0.566)$ & $(0.155)$ & $(0.070)$ \\
\hline Wald X-sq & $2,304.27$ & 166.55 & & $2,696.97$ & 163.18 & & $2,889.64$ & 247.49 & \\
\hline Pseudo R-sq & & & 0.164 & & & 0.122 & & & 0.153 \\
\hline Total Obs & 8,432 & 7,996 & 7,996 & 10,448 & 9,361 & 9,361 & 12,026 & 10,503 & 10,503 \\
\hline
\end{tabular}

This table reports the effect of frozen-on-request GAAP on false positives using the positive stock return sample. The dependent variable across the nine columns is False Positives_1. P-value based on standard errors adjusted for heteroskedasticity is displayed in parentheses. See the Appendix II for variable definitions. All continuous variables are winsorized at the $1 \%$ and $99 \%$ percentiles. ${ }^{* * *},{ }^{* *}$, and ${ }^{*}$ indicate significance at the $1 \%, 5 \%$, and $10 \%$ levels, respectively. 
TABLE 6

The Effect of Frozen-on-Request GAAP on False Positives - Credit Rating Upgrades

\begin{tabular}{|c|c|c|c|c|c|c|c|c|c|}
\hline & \multicolumn{9}{|c|}{ False Positives_2 } \\
\hline & \multicolumn{3}{|c|}{ Frozen-on-Request vs. Floating } & \multicolumn{3}{|c|}{ Frozen-on-Request vs. Frozen } & \multicolumn{3}{|c|}{$\begin{array}{c}\text { Frozen-on-Request vs. Non-Frozen-on- } \\
\text { Request }\end{array}$} \\
\hline & $\begin{array}{l}\text { Heckman } \\
\text { (1) }\end{array}$ & $\begin{array}{l}\text { Firthlogit } \\
\text { (2) }\end{array}$ & $\begin{array}{l}\text { Probit } \\
\text { (3) }\end{array}$ & $\begin{array}{l}\text { Heckman } \\
\text { (4) }\end{array}$ & $\begin{array}{l}\text { Firthlogit } \\
\quad(5)\end{array}$ & $\begin{array}{l}\text { Probit } \\
(6)\end{array}$ & $\begin{array}{l}\text { Heckman } \\
\text { (7) }\end{array}$ & $\begin{array}{l}\text { Firthlogit } \\
\quad(8)\end{array}$ & $\begin{array}{l}\text { Probit } \\
(9)\end{array}$ \\
\hline Frozen-on- & $-1.538 *$ & $-1.266 * * *$ & $-0.658 * * *$ & $-1.948 * *$ & $-0.523 *$ & $-0.266 * *$ & $-1.851 * *$ & $-0.584 * *$ & $-0.304 * * *$ \\
\hline Request $G A A P$ & $(0.066)$ & $(0.000)$ & $(0.000)$ & $(0.013)$ & $(0.064)$ & $(\mathbf{0 . 0 3 0})$ & $(0.015)$ & $(0.016)$ & $(\mathbf{0 . 0 0 3 )}$ \\
\hline \multirow[t]{2}{*}{ Firm Size } & $-0.154 *$ & $-0.317 * *$ & $-0.145 * *$ & $-0.141 *$ & $-0.452 * * *$ & $-0.230 * * *$ & $-0.145^{*}$ & $-0.352 * * *$ & $-0.171 * * *$ \\
\hline & $(0.066)$ & $(0.029)$ & $(0.017)$ & $(0.077)$ & $(0.001)$ & $(0.000)$ & $(0.058)$ & $(0.007)$ & $(0.008)$ \\
\hline \multirow[t]{2}{*}{ Leverage } & -0.273 & -1.026 & -0.551 & -0.039 & 1.358 & 0.699 & -0.107 & 0.652 & 0.252 \\
\hline & $(0.648)$ & $(0.335)$ & $(0.272)$ & $(0.943)$ & $(0.160)$ & $(0.127)$ & $(0.844)$ & $(0.462)$ & $(0.562)$ \\
\hline \multirow[t]{2}{*}{$R O A$} & $6.318 * * *$ & $9.271 * * *$ & $4.989 * * *$ & $6.113 * * *$ & $4.400 * *$ & $2.190 * *$ & $5.989 * * *$ & $3.141^{*}$ & $1.775^{*}$ \\
\hline & $(0.000)$ & $(0.001)$ & $(0.000)$ & $(0.000)$ & $(0.029)$ & $(0.047)$ & $(0.000)$ & $(0.090)$ & $(0.069)$ \\
\hline \multirow[t]{2}{*}{ Dividend } & $-0.599 * *$ & $-0.854 *$ & $-0.418 * *$ & $-0.627 * *$ & $-0.830 *$ & $-0.480 * *$ & $-0.586 * *$ & -0.466 & -0.275 \\
\hline & $(0.031)$ & $(0.074)$ & $(0.038)$ & $(0.016)$ & $(0.071)$ & $(0.022)$ & $(0.021)$ & $(0.267)$ & $(0.178)$ \\
\hline \multirow[t]{2}{*}{ Collateral } & $0.756 * *$ & -0.049 & 0.024 & $0.725 * *$ & $0.910^{*}$ & $0.345 * *$ & $0.711 * *$ & -0.070 & -0.040 \\
\hline & $(0.021)$ & $(0.911)$ & $(0.894)$ & $(0.024)$ & $(0.066)$ & $(0.025)$ & $(0.023)$ & $(0.841)$ & $(0.782)$ \\
\hline \multirow[t]{2}{*}{ Rating } & -0.012 & -0.045 & 0.008 & -0.050 & -0.041 & -0.051 & -0.029 & 0.034 & 0.018 \\
\hline & $(0.943)$ & $(0.878)$ & $(0.961)$ & $(0.748)$ & $(0.884)$ & $(0.749)$ & $(0.847)$ & $(0.898)$ & $(0.910)$ \\
\hline Covenant & $0.417 * *$ & $1.468 * * *$ & $0.729 * * *$ & $0.358 *$ & $0.948 * * *$ & $0.469 * * *$ & $0.368^{*}$ & $1.344 * * *$ & $0.658 * * *$ \\
\hline Tightness & $(0.044)$ & $(0.000)$ & $(0.000)$ & $(0.065)$ & $(0.003)$ & $(0.000)$ & $(0.052)$ & $(0.000)$ & $(0.000)$ \\
\hline \multirow[t]{2}{*}{ Std_Cash Flows } & 0.000 & -0.000 & -0.000 & 0.000 & 0.001 & 0.000 & 0.000 & -0.000 & -0.000 \\
\hline & $(0.380)$ & $(0.615)$ & $(0.669)$ & $(0.343)$ & $(0.242)$ & $(0.304)$ & $(0.343)$ & $(0.852)$ & $(0.960)$ \\
\hline Wald X-sq & 444.65 & 60.25 & & 555.91 & 70.13 & & 605.45 & 77.76 & \\
\hline Pseudo R-sq & & & 0.162 & & & 0.167 & & & 0.136 \\
\hline Total Obs & 1,320 & 1,273 & 1,273 & 1,717 & 1,512 & 1,512 & 1,952 & 1,700 & 1,700 \\
\hline
\end{tabular}

This table reports the effect of frozen-on-request GAAP on false positives using the credit rating upgrade sample. The dependent variable across the nine columns is False Positives_2. P-value based on standard errors adjusted for heteroskedasticity is displayed in parentheses. See the Appendix II for variable definitions. All continuous variables are winsorized at the $1 \%$ and $99 \%$ percentiles. ${ }^{* * *},{ }^{* *}$, and ${ }^{*}$ indicate significance at the $1 \%, 5 \%$, and $10 \%$ levels, respectively. 
TABLE 7

The Effect of Frozen-on-Request GAAP on False Negatives

\begin{tabular}{|c|c|c|c|c|c|c|c|c|c|}
\hline & \multicolumn{6}{|c|}{ Log(Num_Month) } & \multicolumn{3}{|c|}{ Num_Month } \\
\hline & \multicolumn{2}{|c|}{$\begin{array}{c}\text { Frozen-on-Request vs. } \\
\text { Floating }\end{array}$} & \multicolumn{2}{|c|}{$\begin{array}{c}\text { Frozen-on-Request vs. } \\
\text { Frozen }\end{array}$} & \multicolumn{2}{|c|}{$\begin{array}{c}\text { Frozen-on-Request vs. } \\
\text { Non-Frozen-on- } \\
\text { Request }\end{array}$} & \multirow{2}{*}{$\begin{array}{l}\text { Frozen-on-Request } \\
\text { vs. Floating } \\
\text { Poisson } \\
(7)\end{array}$} & \multirow{2}{*}{$\begin{array}{c}\text { Frozen-on-Request } \\
\text { vs. Frozen } \\
\text { Poisson } \\
(8) \\
\end{array}$} & \multirow{2}{*}{$\begin{array}{l}\text { Frozen-on-Request } \\
\text { vs. Non-Frozen-on- } \\
\text { Request } \\
\text { Poisson } \\
\text { (9) }\end{array}$} \\
\hline & $\begin{array}{c}\text { Heckman } \\
(1)\end{array}$ & $\begin{array}{c}\text { OLS } \\
(2)\end{array}$ & $\begin{array}{l}\text { Heckman } \\
\text { (3) }\end{array}$ & $\begin{array}{c}\text { OLS } \\
(4) \\
\end{array}$ & $\begin{array}{l}\text { Heckman } \\
(5)\end{array}$ & $\begin{array}{c}\text { OLS } \\
(6) \\
\end{array}$ & & & \\
\hline $\begin{array}{l}\text { Frozen-on- } \\
\text { Request GAAP }\end{array}$ & $\begin{array}{c}-0.252 * * * \\
(0.002)\end{array}$ & $\begin{array}{c}-0.286 * * * \\
(0.000)\end{array}$ & $\begin{array}{c}-0.149 * * \\
(0.013)\end{array}$ & $\begin{array}{c}-0.155 * * * \\
(0.008)\end{array}$ & $\begin{array}{c}-0.152 * * * \\
(0.005)\end{array}$ & $\begin{array}{c}-0.176 * * * \\
(0.001)\end{array}$ & $\begin{array}{c}-0.123 * * * \\
(0.000)\end{array}$ & $\begin{array}{c}-0.035 * * * \\
(0.006)\end{array}$ & $\begin{array}{c}-0.055^{* * *} \\
(\mathbf{0 . 0 0 0 )}\end{array}$ \\
\hline Cumret & $\begin{array}{c}-0.839 * * * \\
(0.000)\end{array}$ & $\begin{array}{c}-0.846 * * * \\
(0.000)\end{array}$ & $\begin{array}{c}-0.717 * * * \\
(0.000)\end{array}$ & $\begin{array}{c}-0.717 * * * \\
(0.000)\end{array}$ & $\begin{array}{c}-0.780 * * * \\
(0.000)\end{array}$ & $\begin{array}{c}-0.783 * * * \\
(0.000)\end{array}$ & $\begin{array}{c}-0.440 * * * \\
(0.000)\end{array}$ & $\begin{array}{c}-0.357 * * * \\
(0.000)\end{array}$ & $\begin{array}{c}-0.395 * * * \\
(0.000)\end{array}$ \\
\hline Firm Size & $\begin{array}{c}0.044 \\
(0.143)\end{array}$ & $\begin{array}{c}0.040 \\
(0.188)\end{array}$ & $\begin{array}{c}0.076 * * * \\
(0.007)\end{array}$ & $\begin{array}{c}0.074 * * * \\
(0.009)\end{array}$ & $\begin{array}{l}0.064 * * \\
(0.015)\end{array}$ & $\begin{array}{l}0.058 * * \\
(0.028)\end{array}$ & $\begin{array}{c}0.027 * * * \\
(0.000)\end{array}$ & $\begin{array}{c}0.057 * * * \\
(0.000)\end{array}$ & $\begin{array}{c}0.035^{* * *} \\
(0.000)\end{array}$ \\
\hline Leverage & $\begin{array}{c}-0.423 * * * \\
(0.006)\end{array}$ & $\begin{array}{c}-0.438 * * * \\
(0.004)\end{array}$ & $\begin{array}{l}-0.189 \\
(0.202)\end{array}$ & $\begin{array}{l}-0.186 \\
(0.195)\end{array}$ & $\begin{array}{c}-0.221 * \\
(0.093)\end{array}$ & $\begin{array}{l}-0.208 \\
(0.110)\end{array}$ & $\begin{array}{c}-0.149 * * * \\
(0.000)\end{array}$ & $\begin{array}{l}0.053 * * \\
(0.045)\end{array}$ & $\begin{array}{l}-0.039 \\
(0.111)\end{array}$ \\
\hline$R O A$ & $\begin{array}{c}0.759 * * \\
(0.010)\end{array}$ & $\begin{array}{c}0.861 * * * \\
(0.003)\end{array}$ & $\begin{array}{c}0.314 \\
(0.289)\end{array}$ & $\begin{array}{c}0.311 \\
(0.292)\end{array}$ & $\begin{array}{c}0.283 \\
(0.300)\end{array}$ & $\begin{array}{c}0.309 \\
(0.258)\end{array}$ & $\begin{array}{c}0.470 * * * \\
(0.000)\end{array}$ & $\begin{array}{c}0.134 * * \\
(0.023)\end{array}$ & $\begin{array}{c}0.156^{* * *} \\
(0.004)\end{array}$ \\
\hline Rating & $\begin{array}{c}0.071 * * \\
(0.028)\end{array}$ & $\begin{array}{c}0.079 * * \\
(0.014)\end{array}$ & $\begin{array}{l}0.067 * \\
(0.072)\end{array}$ & $\begin{array}{l}0.066 * \\
(0.074)\end{array}$ & $\begin{array}{c}0.039 \\
(0.254)\end{array}$ & $\begin{array}{c}0.041 \\
(0.231)\end{array}$ & $\begin{array}{c}0.038 * * * \\
(0.000)\end{array}$ & $\begin{array}{c}0.039 * * * \\
(0.000)\end{array}$ & $\begin{array}{c}0.023 * * * \\
(0.000)\end{array}$ \\
\hline Loan Size & $\begin{array}{l}0.064^{*} \\
(0.053)\end{array}$ & $\begin{array}{c}0.064 * * \\
(0.043)\end{array}$ & $\begin{array}{c}0.003 \\
(0.918)\end{array}$ & $\begin{array}{c}0.002 \\
(0.938)\end{array}$ & $\begin{array}{c}0.019 \\
(0.484)\end{array}$ & $\begin{array}{c}0.014 \\
(0.582)\end{array}$ & $\begin{array}{c}0.025 * * * \\
(0.000)\end{array}$ & $\begin{array}{c}-0.016 * * * \\
(0.005)\end{array}$ & $\begin{array}{c}0.002 \\
(0.697)\end{array}$ \\
\hline $\begin{array}{l}\text { Month-to- } \\
\text { Maturity }\end{array}$ & $\begin{array}{c}-0.019 * * * \\
(0.000)\end{array}$ & $\begin{array}{c}-0.019 * * * \\
(0.000)\end{array}$ & $\begin{array}{c}-0.019 * * * \\
(0.000)\end{array}$ & $\begin{array}{c}-0.019 * * * \\
(0.000)\end{array}$ & $\begin{array}{c}-0.017 * * * \\
(0.000)\end{array}$ & $\begin{array}{c}-0.017 * * * \\
(0.000)\end{array}$ & $\begin{array}{c}-0.016 * * * \\
(0.000)\end{array}$ & $\begin{array}{c}-0.018 * * * \\
(0.000)\end{array}$ & $\begin{array}{c}-0.016 * * * \\
(0.000)\end{array}$ \\
\hline Num_Covenant & $\begin{array}{c}-0.052 * * \\
(0.042)\end{array}$ & $\begin{array}{c}-0.061 * * \\
(0.014)\end{array}$ & $\begin{array}{c}0.017 \\
(0.438)\end{array}$ & $\begin{array}{c}0.015 \\
(0.498)\end{array}$ & $\begin{array}{l}-0.014 \\
(0.475)\end{array}$ & $\begin{array}{l}-0.021 \\
(0.289)\end{array}$ & $\begin{array}{c}-0.036 * * * \\
(0.000)\end{array}$ & $\begin{array}{c}0.004 \\
(0.368)\end{array}$ & $\begin{array}{c}-0.013 * * * \\
(0.004)\end{array}$ \\
\hline $\begin{array}{l}\text { Inverse Mills } \\
\text { Ratio }\end{array}$ & $\begin{array}{c}0.255 \\
(0.163)\end{array}$ & & $\begin{array}{c}0.064 \\
(0.717)\end{array}$ & & $\begin{array}{l}0.244 * \\
(0.074)\end{array}$ & & & & \\
\hline Year FE & Yes & Yes & Yes & Yes & Yes & Yes & Yes & Yes & Yes \\
\hline Adjusted R-sq & 0.423 & 0.439 & 0.440 & 0.440 & 0.427 & 0.436 & & & \\
\hline Pseudo R-sq & & & & & & & 0.349 & 0.370 & 0.350 \\
\hline Total Obs & 902 & 926 & 1,123 & 1,127 & 1,302 & 1,310 & 934 & 1,137 & 1,322 \\
\hline
\end{tabular}

This table reports the effect of frozen-on-request GAAP on false negatives. The dependent variable across the first six columns is $\log ($ Num_Month) and in columns 7 to 9 is Num Month. P-value based on standard errors adjusted for heteroskedasticity is displayed in parentheses. See the Appendix II for variable definitions. All continuous variables are winsorized at the $1 \%$ and $99 \%$ percentiles. ${ }^{* * *},{ }^{* *}$, and ${ }^{*}$ indicate significance at the $1 \%, 5 \%$, and $10 \%$ levels, respectively. 
TABLE 8

Standard Setting Activities Relevant to Financial Covenants

\begin{tabular}{|c|c|c|c|}
\hline SFAS & Title & $\begin{array}{c}\text { Effective } \\
\text { date }\end{array}$ & Relevance to covenants \\
\hline 121 & $\begin{array}{l}\text { Accounting for the } \\
\text { Impairment of Long- } \\
\text { Lived Assets and for } \\
\text { Long-Lived Assets to } \\
\text { Be Disposed Of } \\
\end{array}$ & $1995-12-31$ & $\begin{array}{l}\text { Affects assets and losses, } \\
\text { and therefore affects both } \\
\text { capital covenants and } \\
\text { performance covenants. }\end{array}$ \\
\hline 123 & $\begin{array}{l}\text { Accounting for Stock- } \\
\text { Based Compensation }\end{array}$ & $1995-12-31$ & $\begin{array}{l}\text { Affects liabilities, equity, } \\
\text { and expenses, and } \\
\text { therefore affects both } \\
\text { capital covenants and } \\
\text { performance covenants. }\end{array}$ \\
\hline $123 \mathrm{R}$ & Share-Based Payment & $2005-06-15$ & $\begin{array}{l}\text { Affects liabilities, equity, } \\
\text { and expenses, and } \\
\text { therefore affects both } \\
\text { capital covenants and } \\
\text { performance covenants. }\end{array}$ \\
\hline 130 & $\begin{array}{c}\text { Reporting } \\
\text { Comprehensive Income }\end{array}$ & $1997-12-15$ & $\begin{array}{l}\text { Affects comprehensive } \\
\text { income and other } \\
\text { comprehensive income, } \\
\text { and therefore affects } \\
\text { performance covenants. }\end{array}$ \\
\hline
\end{tabular}

Affects assets and

141 Business Combinations 2001-07-01 liabilities, and therefore affects capital covenants.

Criteria to select affected firms

Firms that have a ratio of PP\&E to total assets greater than the Compustat median and have returns in the bottom quartile.

Firms that have a ratio of common stock reserved for conversion to stock options to total common stock outstanding greater than the Compustat median.

Firms that have a ratio of stock option expense to total sales greater than the Compustat median.

Firms that have larger than zero accumulated other comprehensive income.

Firms that have greater than median total assets, and within the above median, firms that have asset growth over last 3 years in the top quartile, and in the top quartile firms that have a ratio of goodwill to total assets greater than the Compustat median.

Firms that have greater than median total assets, and within the above median, firms that have asset growth over last 3 years in the top quartile, and in the top quartile firms that have a ratio of goodwill to total assets greater than the Compustat median.

Affects assets and 141R Business Combinations 2008-12-15 liabilities, and therefore affects capital covenants.
Goodwill and Other Intangible Assets
2001-12-15
Affects assets and expenses, and therefore affects both capital covenants and performance covenants.
Firms that have non-zero goodwill and the one-year lagged returns in the bottom quartile. 
TABLE 8

Standard Setting Activities Relevant to Financial Covenants (Continued)

\begin{tabular}{|c|c|c|c|c|}
\hline SFAS & Title & $\begin{array}{l}\text { Effective } \\
\text { date }\end{array}$ & Relevance to covenants & $\begin{array}{l}\text { Criteria to select affected } \\
\text { firms }\end{array}$ \\
\hline 144 & $\begin{array}{l}\text { Accounting for the } \\
\text { Impairment or Disposal } \\
\text { of Long-Lived Assets }\end{array}$ & $2001-12-15$ & $\begin{array}{l}\text { Affects assets and losses, } \\
\text { and therefore affects both } \\
\text { capital covenants and } \\
\text { performance covenants. }\end{array}$ & $\begin{array}{l}\text { Firms that have PP\&E, or } \\
\text { intangible assets, and have } \\
\text { non-zero discontinued } \\
\text { operations. }\end{array}$ \\
\hline 146 & $\begin{array}{l}\text { Accounting for Costs } \\
\text { Associated with Exit or } \\
\text { Disposal Activities }\end{array}$ & $2002-12-15$ & $\begin{array}{c}\text { Affects liabilities, and } \\
\text { therefore affects capital } \\
\text { covenants. }\end{array}$ & $\begin{array}{l}\text { Firms that have a ratio of } \\
\text { restructuring costs to total } \\
\text { sales greater than the } \\
\text { Compustat median. }\end{array}$ \\
\hline 150 & $\begin{array}{c}\text { Accounting for Certain } \\
\text { Financial Instruments } \\
\text { with Characteristics of } \\
\text { both Liabilities and } \\
\text { Equity } \\
\end{array}$ & $2003-05-31$ & $\begin{array}{l}\text { Affects liabilities, equity, } \\
\text { and assets (in some } \\
\text { circumstances), and } \\
\text { therefore affects capital } \\
\text { covenants. }\end{array}$ & $\begin{array}{l}\text { Firms that have greater } \\
\text { than zero redeemable } \\
\text { preferred stock. }\end{array}$ \\
\hline 151 & Inventory Costs & $2005-06-15$ & $\begin{array}{l}\text { Affects assets and } \\
\text { expenses, and therefore } \\
\text { affects both capital } \\
\text { covenants and } \\
\text { performance covenants. }\end{array}$ & $\begin{array}{l}\text { Firms that have a ratio of } \\
\text { inventory to total assets } \\
\text { greater than the Compustat } \\
\text { median. }\end{array}$ \\
\hline 157 & $\begin{array}{c}\text { Fair Value } \\
\text { Measurements }\end{array}$ & $2007-11-15$ & $\begin{array}{l}\text { Affects assets, liabilities, } \\
\text { gains, and losses, and } \\
\text { therefore affects both } \\
\text { capital covenants and } \\
\text { performance covenants. }\end{array}$ & $\begin{array}{l}\text { Firms that have non-zero } \\
\text { value of financial assets or } \\
\text { financial liabilities. }\end{array}$ \\
\hline 158 & $\begin{array}{l}\text { Employers' Accounting } \\
\text { for Defined Benefit } \\
\text { Pension and Other } \\
\text { Postretirement Plans }\end{array}$ & $2006-12-15$ & $\begin{array}{l}\text { Affects assets, liabilities, } \\
\text { and other comprehensive } \\
\text { income, and therefore } \\
\text { affects both capital } \\
\text { covenants and } \\
\text { performance covenants. }\end{array}$ & $\begin{array}{l}\text { Firms that have non-zero } \\
\text { value of pension and } \\
\text { retirement expense. }\end{array}$ \\
\hline 159 & $\begin{array}{l}\text { The Fair Value Option } \\
\text { for Financial Assets and } \\
\text { Financial Liabilities. }\end{array}$ & $2007-11-15$ & $\begin{array}{l}\text { Affects assets, liabilities, } \\
\text { gains, and losses, and } \\
\text { therefore affects both } \\
\text { capital covenants and } \\
\text { performance covenants. }\end{array}$ & $\begin{array}{l}\text { Firms that have non-zero } \\
\text { value of financial assets or } \\
\text { financial liabilities. }\end{array}$ \\
\hline 160 & $\begin{array}{c}\text { Noncontrolling } \\
\text { Interests in } \\
\text { Consolidated Financial } \\
\text { Statements }\end{array}$ & $2008-12-15$ & $\begin{array}{l}\text { Affects equity and } \\
\text { income, and therefore } \\
\text { affects both capital } \\
\text { covenants and } \\
\text { performance covenants. }\end{array}$ & $\begin{array}{l}\text { Firms that have larger than } \\
\text { zero minority interest on } \\
\text { the balance sheet. }\end{array}$ \\
\hline
\end{tabular}

This table reports 15 SFAS that are most relevant to financial covenants over my research period. I use three criteria to select SFAS. First, SFAS should not be for financial industries such as SFAS 134 and 138, about disclosures such as SFAS 131 and 132, for non-profit firms, nor for nonpublic firms; Second, SFAS should affect financial covenants; Third, it must be feasible to identify affected firms. For each SFAS, I identify its effective date and establish criteria to select affected firms. 
TABLE 9

The Effect of Variation in Standard Setting Activity

\begin{tabular}{|c|c|c|c|c|c|c|}
\hline & \multicolumn{2}{|c|}{ False Positives_1 } & \multicolumn{2}{|c|}{ False Positives_2 } & \multicolumn{2}{|c|}{ Log(Num_Month) } \\
\hline & \multicolumn{2}{|c|}{$\begin{array}{c}\text { Frozen-on-Request vs. Non-Frozen- } \\
\text { on-Request }\end{array}$} & \multicolumn{2}{|c|}{$\begin{array}{c}\text { Frozen-on-Request vs. Non-Frozen- } \\
\text { on-Request }\end{array}$} & \multicolumn{2}{|c|}{$\begin{array}{c}\text { Frozen-on-Request vs. Non-Frozen- } \\
\text { on-Request }\end{array}$} \\
\hline & $\begin{array}{l}\text { Pre } \\
\text { (1) }\end{array}$ & $\begin{array}{l}\text { Post } \\
\text { (2) }\end{array}$ & $\begin{array}{l}\text { Pre } \\
(3)\end{array}$ & $\begin{array}{l}\text { Post } \\
(4)\end{array}$ & $\begin{array}{l}\text { Pre } \\
(5)\end{array}$ & $\begin{array}{l}\text { Post } \\
(6)\end{array}$ \\
\hline Frozen-on-Request GAAP & $\begin{array}{l}-0.866 \\
(0.153)\end{array}$ & $\begin{array}{c}-3.078 * * * \\
(0.000)\end{array}$ & $\begin{array}{c}-3.364 * \\
(0.051)\end{array}$ & $\begin{array}{c}-5.636 * * * \\
(0.000)\end{array}$ & $\begin{array}{l}-0.030 \\
(0.905)\end{array}$ & $\begin{array}{c}-0.191 * * \\
(0.038)\end{array}$ \\
\hline Dividend & $\begin{array}{l}-0.156 \\
(0.329)\end{array}$ & $\begin{array}{l}-0.012 \\
(0.924)\end{array}$ & $\begin{array}{l}-0.540 \\
(0.268)\end{array}$ & $\begin{array}{l}-0.601 * \\
(0.079)\end{array}$ & & \\
\hline Collateral & $\begin{array}{l}0.810 * * * \\
(0.000)\end{array}$ & $\begin{array}{l}1.011 * * * \\
(0.000)\end{array}$ & $\begin{array}{c}0.923 \\
(0.114)\end{array}$ & $\begin{array}{l}1.227 * * * \\
(0.006)\end{array}$ & & \\
\hline Covenant Tightness & $\begin{array}{l}-0.324 * * \\
(0.048)\end{array}$ & $\begin{array}{l}-0.019 \\
(0.888)\end{array}$ & $\begin{array}{l}1.038 * * * \\
(0.006)\end{array}$ & $\begin{array}{l}0.788 * * * \\
(0.003)\end{array}$ & & \\
\hline Std_Cash Flows & $\begin{array}{l}-0.002 \\
(0.254)\end{array}$ & $\begin{array}{l}-0.003 * \\
(0.055)\end{array}$ & $\begin{array}{l}0.001 * * \\
(0.026)\end{array}$ & $\begin{array}{l}0.001 * \\
(0.082)\end{array}$ & & \\
\hline Firm Size & $\begin{array}{c}-0.241 * * * \\
(0.001)\end{array}$ & $\begin{array}{l}-0.015 \\
(0.807)\end{array}$ & $\begin{array}{c}0.099 \\
(0.658)\end{array}$ & $\begin{array}{c}0.122 \\
(0.384)\end{array}$ & $\begin{array}{c}0.252 * * * \\
(0.002)\end{array}$ & $\begin{array}{c}0.014 \\
(0.672)\end{array}$ \\
\hline Leverage & $\begin{array}{c}-0.802 * \\
(0.055)\end{array}$ & $\begin{array}{c}-0.595^{*} \\
(0.050)\end{array}$ & $\begin{array}{c}1.036 \\
(0.306)\end{array}$ & $\begin{array}{l}1.349^{*} \\
(0.055)\end{array}$ & $\begin{array}{l}-0.616 \\
(0.210)\end{array}$ & $\begin{array}{c}0.012 \\
(0.945)\end{array}$ \\
\hline$R O A$ & $\begin{array}{c}-3.965 * * * \\
(0.000)\end{array}$ & $\begin{array}{c}-1.855^{* *} \\
(0.018)\end{array}$ & $\begin{array}{c}6.048 * * * \\
(0.002)\end{array}$ & $\begin{array}{c}7.360 * * * \\
(0.000)\end{array}$ & $\begin{array}{c}0.090 \\
(0.895)\end{array}$ & $\begin{array}{c}-0.533^{*} \\
(0.075)\end{array}$ \\
\hline Rating & $\begin{array}{l}-0.113 \\
(0.225)\end{array}$ & $\begin{array}{l}-0.099 \\
(0.190)\end{array}$ & $\begin{array}{c}0.201 \\
(0.535)\end{array}$ & $\begin{array}{l}-0.155 \\
(0.491)\end{array}$ & $\begin{array}{c}0.017 \\
(0.319)\end{array}$ & $\begin{array}{c}-0.019 * * \\
(0.017)\end{array}$ \\
\hline Inverse Mills Ratio & & & & & $\begin{array}{c}-0.224 * * \\
(0.049)\end{array}$ & $\begin{array}{l}-0.083 \\
(0.538)\end{array}$ \\
\hline Cumret & & & & & $\begin{array}{c}-2.120 * * * \\
(0.000)\end{array}$ & $\begin{array}{c}-1.119 * * * \\
(0.000)\end{array}$ \\
\hline Loan Size & & & & & $\begin{array}{c}-0.203 * * \\
(0.029)\end{array}$ & $\begin{array}{c}0.013 \\
(0.770)\end{array}$ \\
\hline Month-to-Maturity & & & & & $\begin{array}{c}-0.025 * * * \\
(0.000)\end{array}$ & $\begin{array}{c}-0.022 * * * \\
(0.000)\end{array}$ \\
\hline Num_Covenant & & & & & $\begin{array}{l}-0.109 \\
(0.138)\end{array}$ & $\begin{array}{c}0.037 \\
(0.234)\end{array}$ \\
\hline
\end{tabular}




\begin{tabular}{lcccccc} 
Wald X-sq & 774.30 & $1,814.18$ & 44.64 & 335.60 & 0.533 & 0.395 \\
Adjusted R-sq & & & & & 1,154 & 153 \\
Total Obs & 4,551 & 7,608 & 752 & 597 \\
\hline
\end{tabular}

This table reports the effect of variation in standard setting activity. The dependent variable in columns 1 and 2 is False Positives_1; in columns 3 and 4 is False Positives_2; and in columns 5 and 6 is Log(Num_Month). P-value based on standard errors adjusted for heteroskedasticity is displayed in parentheses. See the Appendix II for variable definitions. All continuous variables are winsorized at the $1 \%$ and $99 \%$ percentiles. ${ }^{* * *},{ }^{* *}$, and ${ }^{*}$ indicate significance at the $1 \%, 5 \%$, and $10 \%$ levels, respectively. 
TABLE 10

The Effect of Two Types of Frozen-on-Request GAAP on False Positives and False Negatives

\begin{tabular}{|c|c|c|c|c|c|c|}
\hline & \multicolumn{2}{|c|}{ False Positives_1 } & \multicolumn{2}{|c|}{ False Positives_2 } & \multicolumn{2}{|c|}{$\log ($ Num_Month) } \\
\hline & $\begin{array}{l}\text { Frozen-on-Request } \\
\text { with Renegotiation } \\
\text { vs. Non-Frozen- } \\
\text { on-Request } \\
\text { (1) }\end{array}$ & $\begin{array}{c}\text { Frozen-on-Request } \\
\text { without Renegotiation } \\
\text { vs. Non-Frozen-on- } \\
\text { Request } \\
(2)\end{array}$ & $\begin{array}{c}\text { Frozen-on-Request } \\
\text { with Renegotiation } \\
\text { vs. Non-Frozen-on- } \\
\text { Request } \\
\text { (3) }\end{array}$ & $\begin{array}{c}\text { Frozen-on-Request } \\
\text { without Renegotiation } \\
\text { vs. Non-Frozen-on- } \\
\text { Request } \\
(4)\end{array}$ & $\begin{array}{c}\text { Frozen-on-Request } \\
\text { with Renegotiation } \\
\text { vs. Non-Frozen-on- } \\
\text { Request } \\
(5)\end{array}$ & $\begin{array}{c}\text { Frozen-on-Request } \\
\text { without Renegotiation } \\
\text { vs. Non-Frozen-on- } \\
\text { Request } \\
(6)\end{array}$ \\
\hline Frozen-on-Request & -0.386 & $-3.048 * * *$ & 0.514 & $-1.706^{* *}$ & $-0.293 * * *$ & -0.015 \\
\hline$G A A P$ & $(0.628)$ & $(0.000)$ & $(0.794)$ & $(0.045)$ & $(0.000)$ & (0.811) \\
\hline Dividend & $\begin{array}{l}-0.361 \\
(0113)\end{array}$ & $\begin{array}{l}-0.151 \\
(0324)\end{array}$ & $\begin{array}{c}0.274 \\
(0737)\end{array}$ & $\begin{array}{l}-0.356 \\
(0226)\end{array}$ & & \\
\hline Collateral & $\begin{array}{c}0.155 \\
(0.583)\end{array}$ & $\begin{array}{c}0.675 * * * \\
(0.003)\end{array}$ & $\begin{array}{l}-0.161 \\
(0.693)\end{array}$ & $\begin{array}{c}0.772 * * \\
(0.045)\end{array}$ & & \\
\hline Covenant Tightness & $\begin{array}{l}-0.005 \\
(0.984)\end{array}$ & $\begin{array}{c}0.192 \\
(0.247)\end{array}$ & $\begin{array}{c}1.909 * * * \\
(0.001)\end{array}$ & $\begin{array}{c}0.288 \\
(0.205)\end{array}$ & & \\
\hline Std_Cash Flows & $\begin{array}{l}-0.001 \\
(0.765)\end{array}$ & $\begin{array}{c}-0.006^{* *} \\
(0.020)\end{array}$ & $\begin{array}{c}-0.007 * * \\
(0.012)\end{array}$ & $\begin{array}{c}0.001 \\
(0.129)\end{array}$ & & \\
\hline Firm Size & $\begin{array}{c}-0.492 * * * \\
(0.000)\end{array}$ & $\begin{array}{c}0.010 \\
(0.889)\end{array}$ & $\begin{array}{c}0.922 * * * \\
(0.005)\end{array}$ & $\begin{array}{c}-0.169 * * \\
(0.038)\end{array}$ & $\begin{array}{c}0.075 * * \\
(0.038)\end{array}$ & $\begin{array}{c}0.045 \\
(0.153)\end{array}$ \\
\hline Leverage & $\begin{array}{l}-0.422 \\
(0.439)\end{array}$ & $\begin{array}{l}-0.465 \\
(0.164)\end{array}$ & $\begin{array}{c}-7.020 * * * \\
(0.001)\end{array}$ & $\begin{array}{c}0.447 \\
(0.485)\end{array}$ & $\begin{array}{l}-0.226 \\
(0.143)\end{array}$ & $\begin{array}{l}-0.093 \\
(0.533)\end{array}$ \\
\hline$R O A$ & $\begin{array}{c}2.254 \\
(0.145)\end{array}$ & $\begin{array}{c}-3.893 * * * \\
(0.000)\end{array}$ & $\begin{array}{l}6.560 * \\
(0.063)\end{array}$ & $\begin{array}{c}5.927 * * * \\
(0.000)\end{array}$ & $\begin{array}{c}0.126 \\
(0.722)\end{array}$ & $\begin{array}{l}-0.143 \\
(0.663)\end{array}$ \\
\hline Rating & $\begin{array}{c}-0.249 * \\
(0.082)\end{array}$ & $\begin{array}{l}-0.120 \\
(0.148)\end{array}$ & $\begin{array}{l}1.713 * * \\
(0.020)\end{array}$ & $\begin{array}{c}0.014 \\
(0.935)\end{array}$ & $\begin{array}{c}0.023 \\
(0.665)\end{array}$ & $\begin{array}{c}0.001 \\
(0.985)\end{array}$ \\
\hline Inverse Mills Ratio & & & & & $\begin{array}{c}0.203 \\
(0.130)\end{array}$ & $\begin{array}{c}0.101 \\
(0.402)\end{array}$ \\
\hline Cumret & & & & & $\begin{array}{c}-0.819 * * * \\
(0.000)\end{array}$ & $\begin{array}{c}-0.729 * * * \\
(0.000)\end{array}$ \\
\hline Loan Size & & & & & $\begin{array}{c}0.016 \\
(0.616)\end{array}$ & $\begin{array}{l}-0.006 \\
(0.837)\end{array}$ \\
\hline Month-to-Maturity & & & & & $\begin{array}{c}-0.016 * * * \\
(0.000)\end{array}$ & $\begin{array}{c}-0.014 * * * \\
(0.000)\end{array}$ \\
\hline Num_Covenant & & & & & -0.012 & $-0.058 * * *$ \\
\hline
\end{tabular}


Wald X-sq

Adjusted R-sq

Total Obs

6,458
$1,321.81$

6,590
63.47

936
406.35

1,160

0.453 908
0.491

876

This table reports the effect of the two types of frozen-on-request GAAP vs. frozen and floating GAAP on false positives and false negatives. The dependent variable in columns 1 and 2 is False Positives_1, in Columns 3 and 4 is False Positives_2, and in columns 5 and 6 is Log(Num_Month). P-value based on standard errors adjusted for heteroskedasticity is displayed in parentheses. See the Appendix II for variable definitions. All continuous variables are winsorized at the $1 \%$ and $99 \%$ percentiles. ${ }^{* * *},{ }^{* *}$, and ${ }^{*}$ indicate significance at the $1 \%, 5 \%$, and $10 \%$ levels, respectively. 
TABLE 11

The Effect of Financial Crisis 2007-2008

\begin{tabular}{lcc}
\hline & \multicolumn{2}{c}{ False Positives_l } \\
\cline { 2 - 3 } & Frozen-on-Request vs. Non-Frozen-on-Request \\
& Except 2007-2008 & $2007-2008$ \\
\hline Frozen-on-Request GAAPP & $-\mathbf{1 . 3 0 8} * * *$ & $(2)$ \\
Dividend & $(\mathbf{0 . 0 0 0 )}$ & $\mathbf{- 1 . 0 3 5}$ \\
& $-0.417^{* * *}$ & $\mathbf{( 0 . 2 9 9 )}$ \\
Covenant Tightness & $(0.001)$ & 0.550 \\
& $0.368^{* * *}$ & $(0.145)$ \\
Std_Cash Flows & $(0.003)$ & $-1.053^{* *}$ \\
& 0.000 & $(0.039)$ \\
Firm Size & $(0.244)$ & -0.010 \\
& $-0.160^{* * *}$ & $(0.103)$ \\
Leverage & $(0.001)$ & 0.107 \\
& 0.048 & $(0.524)$ \\
ROA & $(0.841)$ & -1.080 \\
& $-1.759^{* *}$ & $(0.187)$ \\
Rating & $(0.018)$ & -2.265 \\
& 0.003 & $(0.186)$ \\
Wald X-sq & $(0.967)$ & $0.393^{*}$ \\
Adjusted R-sq & & $(0.089)$ \\
Total Obs & $2,405.27$ & 359.17 \\
\end{tabular}

This table reports the results of the effect of financial crisis 2007-2008 on frozen-on-request GAAP's advantages in reducing false positives. The dependent variable is False Positives_1. P-value based on standard errors adjusted for heteroskedasticity is displayed in parentheses. See the Appendix II for variable definitions. All continuous variables are winsorized at the $1 \%$ and $99 \%$ percentiles. ${ }^{* * *},{ }^{* *}$, and ${ }^{*}$ indicate significance at the $1 \%, 5 \%$, and $10 \%$ levels, respectively. 
TABLE 12

The Effect of Borrowers' and Lenders' Conflicting Preferences towards GAAP Changes - SFAS 159

\begin{tabular}{|c|c|c|c|c|c|c|}
\hline & \multicolumn{2}{|c|}{ False Positives_1 } & \multicolumn{2}{|c|}{ False Positives_2 } & \multicolumn{2}{|c|}{ Log(Num_Month) } \\
\hline & Conflicting & The Same & Conflicting & The Same & Conflicting & The Same \\
\hline & Preference: & Preference: & Preference: & Preference: & Preference: & Preference: \\
\hline & Unreliable & Unreliable & Unreliable & Unreliable & Unreliable & Unreliable \\
\hline & $\begin{array}{c}\mathrm{FV}>\text { Median } \\
(1)\end{array}$ & $\begin{array}{c}\mathrm{FV}<\text { Median } \\
(2)\end{array}$ & $\begin{array}{c}\mathrm{FV}>\text { Median } \\
(3)\end{array}$ & $\begin{array}{c}\mathrm{FV}<\text { Median } \\
(4)\end{array}$ & $\begin{array}{c}\mathrm{FV}>\text { Median } \\
(5)\end{array}$ & $\begin{array}{c}\mathrm{FV}<\text { Median } \\
(6)\end{array}$ \\
\hline Frozen-on-Request & -1.069 & $-2.838 * *$ & 1.617 & $-2.630 * *$ & 0.112 & -0.202 \\
\hline$G \boldsymbol{A} \boldsymbol{A P}$ & $(0.314)$ & $(0.048)$ & $(0.489)$ & $(0.047)$ & $(0.503)$ & $(0.391)$ \\
\hline \multirow[t]{2}{*}{ Dividend } & -0.673 & 0.432 & -4.904 & -5.842 & & \\
\hline & $(0.691)$ & $(0.650)$ & $(0.355)$ & $(0.131)$ & & \\
\hline \multirow[t]{2}{*}{ Collateral } & -2.626 & -0.185 & 2.510 & 1.556 & & \\
\hline & $(0.191)$ & $(0.859)$ & $(0.286)$ & $(0.221)$ & & \\
\hline \multirow[t]{2}{*}{ Covenant Tightness } & 0.633 & -0.222 & 2.340 & -0.912 & & \\
\hline & $(0.554)$ & $(0.864)$ & $(0.403)$ & $(0.601)$ & & \\
\hline \multirow[t]{2}{*}{ Std_Cash Flows } & -0.009 & 0.000 & 0.001 & -0.001 & & \\
\hline & $(0.258)$ & $(0.864)$ & $(0.794)$ & $(0.296)$ & & \\
\hline \multirow[t]{2}{*}{ Firm Size } & -0.478 & -0.279 & 0.796 & -0.728 & $-0.143 * *$ & 0.053 \\
\hline & $(0.335)$ & $(0.519)$ & $(0.194)$ & $(0.430)$ & $(0.025)$ & $(0.567)$ \\
\hline \multirow[t]{2}{*}{ Leverage } & $5.080 *$ & -2.670 & -2.880 & 5.642 & -0.256 & 0.381 \\
\hline & $(0.078)$ & $(0.352)$ & $(0.703)$ & $(0.361)$ & $(0.428)$ & $(0.250)$ \\
\hline \multirow[t]{2}{*}{$R O A$} & $-8.575^{*}$ & -1.987 & 7.277 & -17.169 & -0.015 & 1.171 \\
\hline & $(0.088)$ & $(0.635)$ & $(0.634)$ & $(0.196)$ & $(0.979)$ & $(0.209)$ \\
\hline \multirow[t]{2}{*}{ Rating } & -0.097 & 0.424 & -2.488 & -3.136 & 0.001 & -0.038 \\
\hline & $(0.872)$ & $(0.422)$ & $(0.365)$ & $(0.145)$ & $(0.960)$ & $(0.111)$ \\
\hline \multirow[t]{2}{*}{ Inverse Mills Ratio } & & & & & 0.159 & -0.377 \\
\hline & & & & & $(0.377)$ & $(0.112)$ \\
\hline \multirow[t]{2}{*}{ Cumret } & & & & & -0.041 & $-2.229 * * *$ \\
\hline & & & & & $(0.871)$ & $(0.000)$ \\
\hline \multirow[t]{2}{*}{ Loan Size } & & & & & -0.041 & -0.100 \\
\hline & & & & & $(0.578)$ & $(0.361)$ \\
\hline \multirow[t]{2}{*}{ Month-to-Maturity } & & & & & $-0.010 * *$ & $-0.017 * * *$ \\
\hline & & & & & $(0.014)$ & $(0.002)$ \\
\hline Num_Covenant & & & & & $-0.148 * * *$ & $0.159 * *$ \\
\hline
\end{tabular}


Wald X-sq

Adjusted R-sq

Total Obs

1,117
10.36

183

7.19
0.400

90

This table reports the effect of borrowers' and lenders' conflicting preferences towards GAAP changes using the setting of SFAS 159. When borrowers have reliable fair value measure (i.e., the ratio of Level 2 and 3 assets and liabilities to total financial assets and liabilities reported in the first fiscal year that begins after November 15 , 2007 is lower than the median value), both borrowers and lenders prefer the adoption of SFAS 159; when borrowers have unreliable fair value measure (i.e., the ratio is higher than the median value), then borrowers prefer to adopt the GAAP changes but lenders prefer not. I use a sample of firms having financial assets and financial liabilities over the three years after the adoption of SFAS 159. The dependent variable in columns 1 and 2 is False Positives_1, in Columns 3 and 4 is False Positives 2, and in columns 5 and 6 is $\log (\mathrm{Num}$ Month). P-value based on standard errors adjusted for heteroskedasticity is displayed in parentheses. See the Appendix II for variable definitions. All continuous variables are winsorized at the $1 \%$ and $99 \%$ percentiles. ${ }^{* * *},{ }^{* *}$, and ${ }^{*}$ indicate significance at the $1 \%, 5 \%$, and $10 \%$ levels, respectively. 
TABLE 13

The Effect of Frozen-on-Request on Loan Spreads

\begin{tabular}{|c|c|c|c|c|c|c|}
\hline & \multicolumn{6}{|c|}{ Spread } \\
\hline & \multicolumn{2}{|c|}{ Frozen-on-Request vs. Frozen } & \multicolumn{2}{|c|}{ Frozen-on-Request vs. Floating } & \multicolumn{2}{|c|}{$\begin{array}{c}\text { Frozen-on-Request vs. Non-Frozen-on- } \\
\text { Request }\end{array}$} \\
\hline & $\begin{array}{l}\text { Heckman } \\
(1)\end{array}$ & $\begin{array}{l}\text { OLS } \\
(2)\end{array}$ & $\begin{array}{l}\text { Heckman } \\
\text { (3) }\end{array}$ & $\begin{array}{l}\text { OLS } \\
(4)\end{array}$ & $\begin{array}{c}\text { Heckman } \\
(5)\end{array}$ & $\begin{array}{c}\text { OLS } \\
(6) \\
\end{array}$ \\
\hline Frozen-on- & $-8.233 * * *$ & $-14.468 * * *$ & -1.319 & $-8.526 *$ & $-6.773 * * *$ & $-13.112 * * *$ \\
\hline Request GAAP & $(0.003)$ & $(0.000)$ & $(0.780)$ & $(0.059)$ & $(\mathbf{0 . 0 0 7 )}$ & $(0.000)$ \\
\hline Leverage & 2.238 & $26.857 * * *$ & $38.155^{* * *}$ & $40.480 * * *$ & $16.619 * *$ & $30.684 * * *$ \\
\hline & $(0.762)$ & $(0.000)$ & $(0.000)$ & $(0.000)$ & $(0.023)$ & $(0.000)$ \\
\hline$R O A$ & $\begin{array}{l}-117.375 * * * \\
\quad(0.000)\end{array}$ & $\begin{array}{l}-251.404 * * * \\
(0.000)\end{array}$ & $\begin{array}{l}-195.588 * * * \\
\quad(0.000)\end{array}$ & $\begin{array}{l}-215.209 * * * \\
(0.000)\end{array}$ & $\begin{array}{l}-200.961 * * * \\
(0.000)\end{array}$ & $\begin{array}{l}-265.462 * * * \\
\quad(0.000)\end{array}$ \\
\hline Rating & $\begin{array}{l}30.092 * * * \\
(0.000)\end{array}$ & $\begin{array}{l}30.099 * * * \\
(0.000)\end{array}$ & $\begin{array}{l}29.678 * * * \\
(0.000)\end{array}$ & $\begin{array}{l}28.758 * * * \\
(0.000)\end{array}$ & $\begin{array}{l}31.181 * * * \\
(0.000)\end{array}$ & $\begin{array}{l}33.281 * * * \\
(0.000)\end{array}$ \\
\hline Loan/Asset & $\begin{array}{c}24.422 * * * \\
(0.000)\end{array}$ & $\begin{array}{c}5.181 \\
(0.490)\end{array}$ & $\begin{array}{l}17.320^{* *} \\
(0.039)\end{array}$ & $\begin{array}{l}13.944 * \\
(0.097)\end{array}$ & $\begin{array}{c}23.271 * * * \\
(0.001)\end{array}$ & $\begin{array}{c}9.907 \\
(0.167)\end{array}$ \\
\hline Maturity & $\begin{array}{c}1.637^{* * *} \\
(0.000)\end{array}$ & $\begin{array}{c}1.870 * * * \\
(0.000)\end{array}$ & $\begin{array}{c}1.504 * * * \\
(0.000)\end{array}$ & $\begin{array}{c}1.549 * * * \\
(0.000)\end{array}$ & $\begin{array}{c}1.293 * * * \\
(0.000)\end{array}$ & $\begin{array}{c}1.433 * * * \\
(0.000)\end{array}$ \\
\hline Num_Covenant & $\begin{array}{c}1.187 \\
(0.301)\end{array}$ & $\begin{array}{c}1.300 \\
(0.301)\end{array}$ & $\begin{array}{c}0.548 \\
(0.681)\end{array}$ & $\begin{array}{l}-0.095 \\
(0.943)\end{array}$ & $\begin{array}{l}2.069 * \\
(0.064)\end{array}$ & $\begin{array}{c}1.337 \\
(0.237)\end{array}$ \\
\hline Inverse Mills Ratio & $\begin{array}{c}186.063 * * * \\
(0.000)\end{array}$ & & $\begin{array}{c}49.537 * * * \\
(0.000)\end{array}$ & & $\begin{array}{c}101.292 * * * \\
(0.000)\end{array}$ & \\
\hline Loan Purpose FE & Yes & Yes & Yes & Yes & Yes & Yes \\
\hline Year FE & Yes & Yes & Yes & Yes & Yes & Yes \\
\hline Adjusted R-sq & 0.544 & 0.516 & 0.530 & 0.526 & 0.538 & 0.521 \\
\hline Total Obs & 4,831 & 4,860 & 3,979 & 3,982 & 5,370 & 5,373 \\
\hline
\end{tabular}

This table reports the effect of frozen-on-request GAAP on loan spreads. The dependent variable across the six columns $S p r e a d$. $P$-value based on standard errors adjusted for heteroskedasticity is displayed in parentheses. See the Appendix II for variable definitions. All continuous variables are winsorized at the $1 \%$ and $99 \%$ percentiles. ${ }^{* * *},{ }^{* *}$, and ${ }^{*}$ indicate significance at the $1 \%, 5 \%$, and $10 \%$ levels, respectively. 
TABLE 14

The Effect of Frozen-on-Request GAAP on False Positives - Positive Bond Returns

\begin{tabular}{|c|c|c|c|c|c|c|c|c|c|}
\hline & \multicolumn{9}{|c|}{ False Positives 3} \\
\hline & \multicolumn{3}{|c|}{ Frozen-on-Request vs. Floating } & \multicolumn{3}{|c|}{ Frozen-on-Request vs. Frozen } & \multicolumn{3}{|c|}{$\begin{array}{l}\text { Frozen-on-Request vs. Non-Frozen-on- } \\
\text { Request }\end{array}$} \\
\hline & $\begin{array}{l}\text { Heckman } \\
\text { (1) }\end{array}$ & $\begin{array}{l}\text { Firthlogit } \\
(2)\end{array}$ & $\begin{array}{l}\text { Probit } \\
\text { (3) }\end{array}$ & $\begin{array}{c}\text { Heckman } \\
\text { (4) }\end{array}$ & $\begin{array}{l}\text { Firthlogit } \\
(5)\end{array}$ & $\begin{array}{l}\text { Probit } \\
(6)\end{array}$ & $\begin{array}{l}\text { Heckman } \\
\text { (7) }\end{array}$ & $\begin{array}{c}\text { Firthlogit } \\
\text { (8) }\end{array}$ & $\begin{array}{c}\text { Probit } \\
(9)\end{array}$ \\
\hline Frozen-on- & $-2.092 * * *$ & $-1.001 * * *$ & $-0.348 * * *$ & $-2.188 * * *$ & $-0.743 * * *$ & $-0.279 * * *$ & $-2.268 * * *$ & $-0.868 * * *$ & $-0.327 * * *$ \\
\hline Request $G A A P$ & $(0.000)$ & $(0.000)$ & $(\mathbf{0 . 0 0 2})$ & $(\mathbf{0 . 0 0 0 )}$ & $(\mathbf{0 . 0 0 2})$ & $(\mathbf{0 . 0 0 2})$ & $(0.000)$ & $(0.000)$ & $(\mathbf{0 . 0 0 0 )}$ \\
\hline \multirow[t]{2}{*}{ Firm Size } & -0.092 & -0.253 & -0.113 & -0.090 & -0.087 & -0.051 & -0.084 & -0.097 & -0.048 \\
\hline & $(0.314)$ & $(0.236)$ & $(0.174)$ & $(0.314)$ & $(0.624)$ & $(0.467)$ & $(0.342)$ & $(0.553)$ & $(0.458)$ \\
\hline \multirow[t]{2}{*}{ Leverage } & -0.044 & -1.060 & -0.293 & -0.074 & -0.680 & -0.184 & -0.034 & -0.915 & -0.299 \\
\hline & $(0.922)$ & $(0.317)$ & $(0.478)$ & $(0.865)$ & $(0.432)$ & $(0.600)$ & $(0.938)$ & $(0.264)$ & $(0.362)$ \\
\hline \multirow[t]{2}{*}{$R O A$} & $-3.342 * * *$ & $-9.107 * * *$ & $-3.750 * * *$ & $-3.437 * * *$ & $-7.865 * * *$ & $-3.347 * * *$ & $-3.301 * * *$ & $-8.616 * * *$ & $-3.573 * * *$ \\
\hline & $(0.004)$ & $(0.001)$ & $(0.000)$ & $(0.002)$ & $(0.001)$ & $(0.000)$ & $(0.003)$ & $(0.000)$ & $(0.000)$ \\
\hline \multirow[t]{2}{*}{ Dividend } & -0.125 & 0.129 & 0.001 & -0.117 & -0.317 & -0.166 & -0.122 & -0.031 & -0.062 \\
\hline & $(0.580)$ & $(0.818)$ & $(0.995)$ & $(0.593)$ & $(0.463)$ & $(0.329)$ & $(0.575)$ & $(0.939)$ & $(0.706)$ \\
\hline \multirow[t]{2}{*}{ Collateral } & -0.131 & $-0.762 * *$ & $-0.274 * *$ & -0.145 & 0.013 & -0.005 & -0.134 & -0.379 & -0.127 \\
\hline & $(0.410)$ & $(0.038)$ & $(0.044)$ & $(0.351)$ & $(0.968)$ & $(0.964)$ & $(0.383)$ & $(0.161)$ & $(0.214)$ \\
\hline Covenant & $0.370 * *$ & $1.792 * * *$ & $0.607 * * *$ & $0.326 * *$ & $0.620 * *$ & $0.221 *$ & $0.344 * *$ & $1.301 * * *$ & $0.444 * * *$ \\
\hline Tightness & $(0.018)$ & $(0.000)$ & $(0.000)$ & $(0.033)$ & $(0.049)$ & $(0.068)$ & $(0.022)$ & $(0.000)$ & $(0.000)$ \\
\hline \multirow[t]{2}{*}{ Rating } & -0.086 & -0.283 & -0.139 & -0.097 & 0.041 & -0.023 & -0.089 & -0.106 & -0.061 \\
\hline & $(0.598)$ & $(0.472)$ & $(0.358)$ & $(0.536)$ & $(0.899)$ & $(0.857)$ & $(0.570)$ & $(0.730)$ & $(0.610)$ \\
\hline \multirow[t]{2}{*}{ Std_Cash Flows } & -0.000 & -0.001 & $-0.001 *$ & -0.000 & -0.000 & -0.000 & -0.000 & $-0.001 *$ & $-0.001 * *$ \\
\hline & $(0.454)$ & $(0.120)$ & $(0.080)$ & $(0.523)$ & $(0.593)$ & $(0.369)$ & $(0.439)$ & $(0.075)$ & $(0.045)$ \\
\hline Wald X-sq & $1,871.78$ & 67.23 & & $2,053.90$ & 66.06 & & $2,186.67$ & 84.72 & \\
\hline Pseudo R-sq & & & 0.096 & & & 0.069 & & & 0.078 \\
\hline Total Obs & 7,534 & 7,534 & 7,534 & 8,734 & 8,734 & 8,734 & 10,059 & 10,059 & 10,059 \\
\hline
\end{tabular}

This table reports the effect of frozen-on-request GAAP on false positives using the positive bond returns sample. The dependent variable across the nine columns is False Positives_3. P-value based on standard errors adjusted for heteroskedasticity is displayed in parentheses. See the Appendix II for variable definitions. All continuous variables are winsorized at the $1 \%$ and $99 \%$ percentiles. ${ }^{* * *},{ }^{* *}$, and ${ }^{*}$ indicate significance at the $1 \%, 5 \%$, and $10 \%$ levels, respectively 